
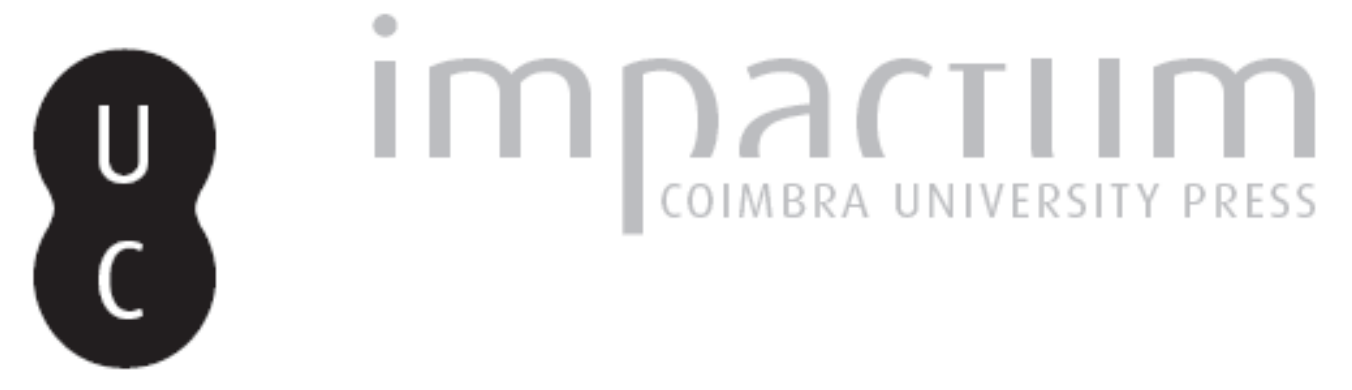

\title{
A oposição eleitoral ao salazarismo
}

\author{
Autor(es): $\quad$ Cruz, Manuel Braga da
}

Publicado por: Imprensa da Universidade de Coimbra

URL persistente:

URI:http://hdl.handle.net/10316.2/45058

DOI:

DOI:https://doi.org/10.14195/2183-8925_5-2_2

Accessed : $\quad$ 26-Apr-2023 12:49:19

A navegação consulta e descarregamento dos títulos inseridos nas Bibliotecas Digitais UC Digitalis, UC Pombalina e UC Impactum, pressupõem a aceitação plena e sem reservas dos Termos e Condições de Uso destas Bibliotecas Digitais, disponíveis em https://digitalis.uc.pt/pt-pt/termos.

Conforme exposto nos referidos Termos e Condições de Uso, o descarregamento de títulos de acesso restrito requer uma licença válida de autorização devendo o utilizador aceder ao(s) documento(s) a partir de um endereço de IP da instituição detentora da supramencionada licença.

Ao utilizador é apenas permitido o descarregamento para uso pessoal, pelo que o emprego do(s) título(s) descarregado(s) para outro fim, designadamente comercial, carece de autorização do respetivo autor ou editor da obra.

Na medida em que todas as obras da UC Digitalis se encontram protegidas pelo Código do Direito de Autor e Direitos Conexos e demais legislação aplicável, toda a cópia, parcial ou total, deste documento, nos casos em que é legalmente admitida, deverá conter ou fazer-se acompanhar por este aviso.

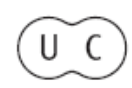




\section{REVISTA DE HISTÓRIA DAS IDEIAS 5}

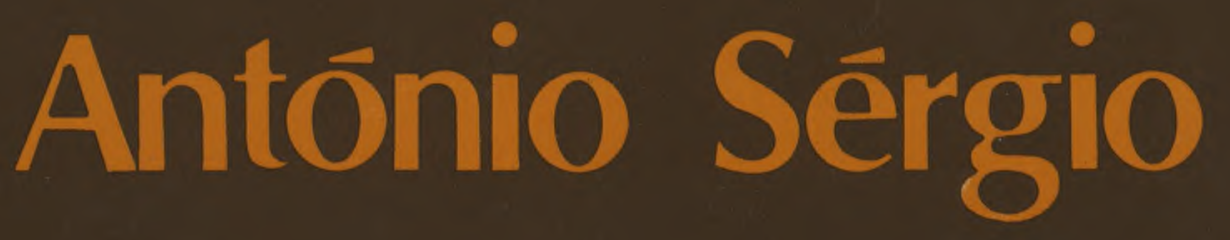

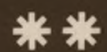

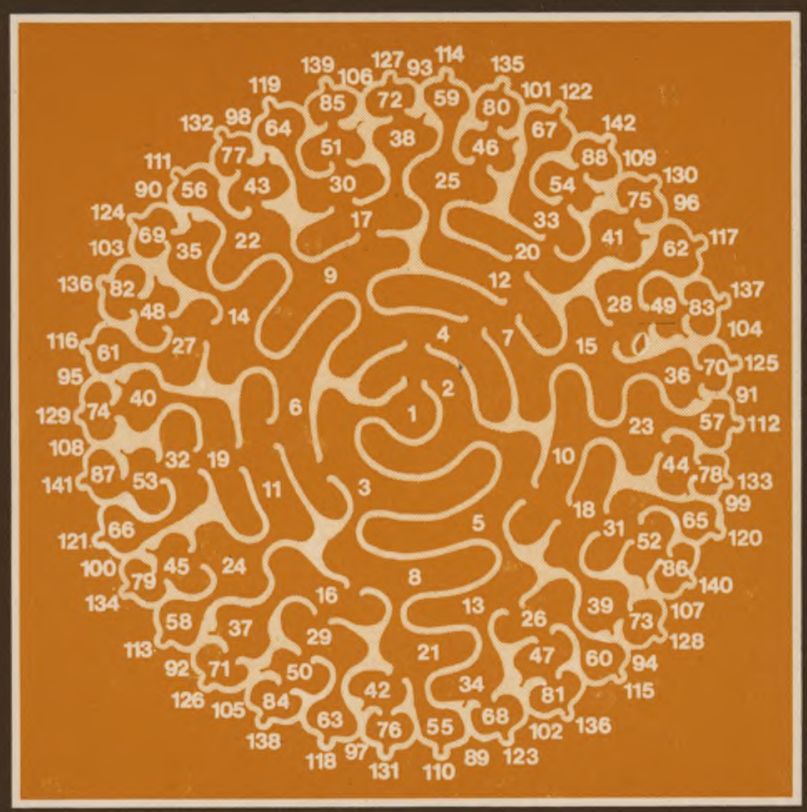

INSTITUTO DE HISTÓRIA E TEORIA DAS IDEIAS FACULDADE DE LETRAS

COIMBRA 1983 


\section{A OPOSIÇÃO ELEITORAL AO SALAZARISMO}

O estudo da oposição é de uma importância decisiva para a caracterização dos modernos regimes políticos, não só em termos substantivos, para a análise das relações de força políticas que corporizam, mas sobretudo em termos formais, para a análise do sistema político que consagram. Deste último ponto de vista, a presença ou ausência legal de uma oposição é mesmo considerada como a característica mais distintiva entre regimes democráticos e regimes ditatoriais $(*)$.

A importância do estudo da oposição para a análise dos regimes democráticos, tal como foi posta em evidência sobretudo por Robert Dalh, prende-se com o facto de se entender que os regimes políticos são caracterizados fundamentalmente pela participação e pela competitividade no e pelo poder $\left(^{2}\right)$. Nessa perspectiva, o estudo da oposição afigura-se por isso tão necessário como o estudo do governo, enquanto forma de controle e de limitação política do poder e do seu exercício.

$\mathrm{O}$ estudo da oposição oferece porém um motivo de suplementar interesse para a análise dos regimes ditatoriais. É que dos limites da sua expressão e actuação pode depender a caracterização sub-típica das ditaduras, nomeadamente a diferenciação entre totalitarismo e autoritarismo. Enquanto

* Instituto de Ciências Sociais da Universidade de Lisboa.

C) Cf. Robert A. Dahl (ed.), Political Oppositions in Western Démocraties, New Haven, London, and Yale University Press 1970 (1966); e Ghita Ionescu and Isabel de Madariaga, Opposition: Past and Presente of a Political Institution, London, 1968; e ainda Rodney Barker (ed.) Studies in Opposition, London, Macmillan, 1971.

C) Cf. Robert A. Dahl, Regimes and Oppositions, New Haven and London, Yale University Press, 1973. 
o primeiro não permitiria qualquer espécie de controle político e, por conseguinte, de oposição, o segundo limitar-se-ia a reprimir mas não a suprimir a manifestação da oposição.

Particular interesse oferece ainda porém o estudo da oposição em regimes ditatoriais autoritários que, além de não a suprimirem, a não reprimem sistemática e permanentemente, não proibindo de todo a sua emergência ocasional, consentindo-lhe alguma esporádica "concorrência controlada». O comportamento eleitoral da oposição afigura-se então particularmente elucidativo não só dessa oposição como do próprio sistema. A oposição deixa então de estar reduzida à clandestinidade para passar a ter um estatuto de semi-legalidade ou de legalidade temporária nos momentos eleitorais. As eleições tornam-se assim o momento-chave para compreender até que ponto a oposição se desclandestiniza e se legaliza, aceitando jogar o jogo do sistema, isto é, a sua constitucionalidade, por um lado, e até que ponto o sistema deixa jogar, ou seja, se deixa controlar ou criticar legalmente e também contitucionalmente, por outro lado. Desse modo, assim como a distinção entre «oposição responsável» e «irresponsável» é relevante para o quadro da oposição constitucional, como sublinha Sartori (3), da mesma maneira, neste caso de oposição semi-constitucional, a diferença importante é entre oposição interna e externa ao sistema que, como precisa Juan Linz, não necessariamente coincide com a oposição legal e ilegal $\left({ }^{4}\right)$.

Esta é a razão pela qual, no âmbito de um estudo mais vasto sobre o salazarismo (5), entendemos necessário debruçar-nos sobre os comportamentos legais, melhor dito eleitorais da oposição. Em primeiro lugar, o comportamento perante a constitucionalidade mesma do regime, que caracteriza e distingue a sua natureza ou colocação interna ou externa em relação ao sistema. Consoante a oposição se dispõe a aceitar ou recusar parcial ou totalmente o quadro constitucional, assim se posiciona estrategicamente em face do regime e das eleições. A alternativa entre acatamento e rotura das bases institucionais do regime condiciona a alternativa estratégica entre os propósitos de reforma ou de revolução no aprovei-

(3) Giovanni Sartori, «Opposition and Control: Problems and Prospects» in R. Barker (ed.), ob. cit., p. 35.

$\left({ }^{4}\right)$ Juan Linz, "Opposition in and under an Authoritarian Regime: The Case of Spain», in Robert A. Dahl, Regimes and Oppositions* ob. cit., pp. 191 e ss.

(5) Este trabalho é parte de um mais vasto estudo realizado no Instituto de Ciências Sociais acerca do salazarismo, com vista à realização de uma tese de doutoramento sobre o partido no Estado Novo. 
tamento das eleições. E condiciona sobretudo as relações internas à própria oposição, entre os seus sectores político-ideológicos mais notórios, desde a unidade de acção à divisão $\mathrm{e}$ variedade de formas de comportamento.

Em segundo lugar, os comportamentos tácticos de actuação em face dos condicionamentos postos pelo governo à concorrência tolerada: desde o abstencionismo à partida, por razões fundamentalmente cívicas e denunciadoras, ao intervencionismo até ao fim, como forma de disputa do direito à existência, passando pelo mero aproveitamento do período de campanha com desistência à boca das urnas, para colher os beneficios propagandísticos e evitar os custos de cooptação.

Antes disso, porém, convém recordar a natureza própria do regime e o papel que nele desempenhou a existência de eleições, combinando simultaneamente objectivos de legislação e de controle políticos.

Urna das características mais distintivas do salazarismo, em relação aos demais regimes autoritários contemporâneos, foi a consagração constitucional do princípio representativo e do princípio electivo, com a instituição de uma Câmara política de representação nacional - a Assembleia Nacional - e a estipulação de mecanismos electivos para a designação da Presidência da República e dessa mesma Assembleia Nacional.

A concretização, porém, desses princípios foi viciada pela ausência de liberdade política e de aplicação de rígidos mecanismos de controle que lhe desvirtuaram a natureza. A representação política do salazarismo foi, ao longo de todo o regime, uma "representação monística», de que o pluralismo formal, nomeadamente partidário, esteve sempre ausente, apesar de um certo pluralismo substancial, com notória evidência sobretudo na legislatura de 1969.-73, com a constituição de uma «ala liberal». E o regime eleitoral, privado da real liberdade de voto de grandes maiorias de cidadãos, converteu-se na prática em sistemas de «eleições sem escolha» $\left.{ }^{(}\right)$.

Não foi sempre o mesmo porém nem o eleitorado nem o regime eleitoral, ao longo do tempo, para a designação quer da chefia do Estado quer da representação política. O eleitorado, configurado não só pelo direito de voto como pelos mecanismos legais e administrativos do recenseamento eleitoral, foi porém sempre fortemente restritivo. Era limitado o direito

(6) Guy Hermet, Alain Rouquié, Juan J. Linz, Des elections pas commes les autres, Presses de la Fondation Nationale des Sciences Politiques, e Richard Rose, Guy Hermet, Alain Rouquié, Elections without Choice, Macmillan, 1978. 
de voto, muitos os impedimentos (sobretudo de ordem política) e fortemente controladas, quer administrativamente quer politicamente, as operações de recenseamento. Tudo isso conformava um eleitorado reduzido e, à partida, maioritariamente afecto ao regime, porque fundamentalmente baseado no funcionalismo público estadual, administrativo e corporativo. $\mathrm{O}$ regime eleitoral, por seu lado, variou também. Para as eleições presidenciais, o sufrágio directo que vigorou até 1958 foi substituído pelo sufrágio orgânico restrito colegial, na revisão constitucional de 1959, a fim de evitar a repetição da possibilidade de um «golpe de Estado constitucional», na conhecida expressão de Salazar. Para as eleições da Assembleia Nacional, o regime, que fora até à guerra plebiscitário e não-concorrencial, isto é de lista única e círculo único, evoluiu a partir de 1945, para um regime de listas e círculos distritais de maioria simples, ou seja, na prática, para um regime de concorrência controlada embora de hegemonia (e até unicidade) garantida $\left({ }^{7}\right)$.

Foi então a partir de 1945, apenas quando o regime eleitoral se abriu a alguma concorrência, se bem que controlada, que a oposição resolveu manifestar-se eleitoralmente.

E certo que a primeira tentativa de participação eleitoral da oposição remonta a 1931, a quando do anúncio das primeiras eleições administrativas ${ }^{8}$ ). A recém-formada Aliança Republicana-Socialista, que reunia internamente as forças republicanas e socialistas de oposição à Ditadura $\left({ }^{9}\right)$, ao serem anunciadas as eleições, aconselhou aos seus correligionários o recenseameento eleitoral e solicitou, a 2 de Junho, uma audiência ao Presidente da República que recebeu, na presença do Ministro do Interior, como seus representantes, o General Norton de Matos e os Contra-Almirantes Mendes Cabeçadas e Tito de Morais. Como pretendessem saber se teriam liberdade de propaganda no caso de a elas concorrerem, foram in-

(7) Para uma mais detalhada exposição sobre a configuração e evolução do eleitorado e do regime eleitoral, bem como sobre o controle dos actos e resultados eleitorais, cf. o capítulo relativo às «Eleições no Estado Novo» do trabalho já referido, de futura publicação, sobre O Partido e o Estado no salazarismo.

C) $O$ recenseamento eleitoral $e$ as eleições foram reguladas então pelo Dec. $n .^{\circ} 19.694$ de 5 de Maio de 1931 .

$(9)$ Dizemos «internamente» porque a 22 e 23 de Novembro desse ano, se realizou no sul de França uma conferência política destinada a criar uma Frente Unida contra a Ditadura que, a par da ARS, no interior, manteria no exterior um Comité Supremo, composto sobretudo por exilados, com o objectivo de preparar a revolução (Cf. Oliveira Marques, Afonso Costa, Arcádia, 1972, pp. 224-225). 
formados pelo governo que a teriam, desde que não fosse por ela atacada a ditadura. No dia seguinte, a 3 de Junho, publicava o Directorio da ARS um Manifesto ao País em que, a par de um apelo ao regresso urgente à normalidade constitucional expunha o ideário democrático comum às forças que congregava: o cidadão como realidade política fundamental, o Estado representativo, a liberdade na sua tríplice expressão política-económica-cultural, a igualdade de oportunidades, o sufrágio universal, a descentralização, a harmonização entre o capital e o trabalho, a necessidade do parlamento e da organização partidária, a harmonia entre o legislativo e o executivo, a independência do poder judicial, a tolerância religiosa, a defesa territorial, a aproximação entre os povos $\left({ }^{10}\right)$.

No entanto, só a partir de finais da 2. ${ }^{a}$ Guerra Mundial, a oposição se decide manifestar eleitoralmente. A vitória aliada obrigava Salazar a dar para o exterior a imagem de uma abertura política, a simular um certo alinhamento «democrático». Marcelo Caetano vai mesmo ao ponto de dizer que era intenção de Salazar tolerar uma oposição colaboracionista desde que não comunista, em ordem a uma «evolução progressiva do regime» $\left({ }^{1 X}\right)$. E Franco Nogueira relata até rumores de ter sido encarregado Albino dos Reis de preparar a transição $\left({ }^{12}\right)$.

Várias medidas, efectivamente, pareciam deixar supô-lo. A 18 de Agosto de 1945, é concedida uma parcial amnistia política a «condenados por crimes contra a segurança exterior e interior do Estado» (13). Dos 200 presos políticos no Campo do Tarrafal e da Fortaleza de Peniche são libertados 98 (14). Dias depois é instituído em Portugal o «habeas corpus», e a censura, que fora redobrada durante a guerra, alargando-se à correspondência, conhece um certo abrandamento, e deixará, legalmente, de existir, no decurso da campanha eleitoral seguinte, para avisos e convocações eleitorais, para notícias e reportagens de campanha, para propaganda de candidatos e apreciações aos actos de governo (15). A 22 de Setembro é promulgada nova lei eleitoral e a 27 do mesmo mês, o Conselho de Estado apoia a proposta do governo para a disso-

(10) República, 3.VIL31.

(u) Marcelo Caetano, Minhas Memórias de Salazar, Lisboa, Verbo, 1977, p. 247.

(12) Franco Nogueira, Salazar, vol. Ill, Coimbra, Atlântida, 1978.

(13) Dec. Lei n. 35.041 de 18 de Agosto de 1945.

(14) Nota Oficiosa do Gabinete do Ministro da Justiça, Diário

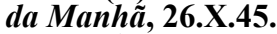

(15) Diário da Manhã, 13.X.45. 
lução da Assembleia Nacional pelo Presidente da República. A imprensa estrangeira reconhece em tais medidas indícios de liberalização política e o Times londrino, por exemplo, acredita mesmo convictamente num «avanço em direcção ao liberalismo por parte de um governo de partido único», graças à «derrocada dos sistemas totalitários por toda a Europa» (16).

O certo é que as eleições, a partir de 1945, deixam apenas de servir para plebiscitação e legitimação do regime, e passam também a funcionar como mecanismo de identificação e controlo político das forças que clandestinamente se opunham ao regime, e ainda como válvula de segurança ou escape regulador de tensões políticas adversas, que poderiam fazer perigar equilíbrios internos. As eleições passaram então a traduzir compromissos concretos entre o governo e a oposição, oscilando consoante a variação de forças globais que entre ambos se estabeleciam na sociedade política portuguesa. Vejamos, pois, como foi evoluindo esse compromisso.

\section{As campanhas unitárias do MUD (1945) e do general Nor-} ton de Matos (1949)

A oposição, que em Dezembro de 1943 se agrupara clandestinamente nas estruturas unitárias do Movimento de Unidade Nacional Anti-Fascista (MUNAF), englobando representantes do PRP, da Esquerda Democrática, da SPIO, da Seara Nova, do PCP, da Maçonaria, e da União Socialista, além de republicanos e democratas independentes, e cujo Conselho Nacional elabora em Agosto de 1944 um Programa de Emergência do Governo Provisório (17), decide-se a tirar partido das novas possibilidades de actuação, nomeadamente da esporádica e ocasional legalização que o regime passa a permitir-lhe. Sem tolerar que se pense no regresso ao parlamentarismo e ao sistema de partidos, Salazar aceita que, por períodos curtos e espaçados, e sempre sob rígido controlo do poder estabelecido - a PVDE é reorganizada e passa a denominar-se PIDE nesse mês de Outubro de $1945\left({ }^{18}\right)$ - se formem o que Mário de Figueiredo classifica impropriamente de «partidos ocasionais» $\left({ }^{19}\right)$.

(1<5) Citado por Diário da Manhã, 14.X.45.

(1T) Magalhăes Godinho, «Salazar, Franco Nogueira e o MUD, I», O Jornal, 9.V.30.

(18) Diário da Manhã, 17.X.45.

(19) Mário de Figueiredo, «Política Nacional cu Politica de Partido», II Conf. da União Nacional, Lisboa, UN, 1949, pp. 35-45. 
A 29 de Setembro, um grupo de oposicionistas $\left({ }^{20}\right)$ solicita ao Governador Civil de Lisboa autorização para poder proceder a uma reunião para examinar se, à luz da nova legislação eleitoral, «devem tomar iniciativa de sugerir, à generalidade de cidadãos eleitores, a necessidade do seu concurso às primeiras eleições legislativas que vierem a realizar-se, no sentido de obterem representação na futura Assembleia Nacional, para as tendências políticas e opiniões que não prestam o seu acordo à orientação política e administrativa do Governo» $(21)$.

Como porém, pouco depois, o Conselho de Estado tivesse aprovado a proposta do Governo de dissolver a Assembleia Nacional, e como a partir da dissolução não podiam ser introduzidas alterações na lei eleitoral, o mesmo grupo de oposicionistas, alargado de mais assinaturas, dirige-se ao Presidente da República a 4 de Outubro, para que antes da dissolução seja ouvida a opinião democrática acerca da mesma legislação eleitoral, opinião essa que seria expressa a partir de uma próxima reunião que fora já solicitada.

A 8 de Outubro de 1945 tem efectivamente lugar no Centro Escolar Republicano Almirante Reis, em Lisboa (22), a reunião presidida pelo Prof. Barbosa de Magalhães que vai dar origem ao MUD, a cuja Comissão Organizadora preside Mário de Lima Alves. O MUD, que em breve revela em Conferência de Imprensa ter conseguido 50.145 assinaturas $\left({ }^{23}\right)$ (mais do que os 48.818 que nas últimas eleições para as Juntas de Freguesia em Lisboa haviam votado pela UN) (24) apresenta publicamente, algumas exigências políticas de democratização do regime para concorrer às eleições, a saber: adiamento de seis meses do acto eleitoral para normalização dos conhecimentos políticos da opinião pública, através da organização de partidos; atribuição de poderes constituintes à nova assembleia; garantia das liberdades de opinião, de reunião e de expressão, a extinção do campo de concentração do Tarrafal, possibilidade de fundação de novos jornais; permi-

$\left.C^{\circ}\right)$ Compunham-no José de Magalhães Godinho, Teófilo Carvalho dos Santos, Armando Adão e Silva, Gustavo Soromenho, Manuel Catarino Duarte, Manuel Mendes, Guilherme Canas Pereira, Afonso Costa (Filho), Luis da Câmara Reis, Alberto Candeias, Mário de Lima Alves.

(21) Cf. Seara Nova, suplemento ao n. ${ }^{\circ} 948$, Ano XXV, 13.X.45.

(22) Situado na Rua do Benformoso, $n .^{\circ} 30$, nome pelo qual pejorativamente o movimento também havia de ser alcunhado nas hostes do regime.

$\left.\mathrm{C}^{23}\right)$ Cf. Seara Nova, suplemento ao n. ${ }^{\circ} 949$ Ano XXV, 26.X.45.

(M) Diário da Manhã, 25.X.45. 
tir a participação política aos emigrados; conceder representação política às minorias; possibilidade de físcalização eleitoral; liberdade de candidaturas ou de capacidade eleitoral passiva; novo recenseamento eleitoral. E dota-se de uma Comissão Central, de cuja Comissão Executiva faziam parte Mário de Lima Alves, Teófilo Carvalho dos Santos e Manuel Mendes.

Em torno destas reivindicações se encontram unánimemente vastos sectores de opinião pública: democratas liberais e republicanos da Esquerda Democrática e do Partido Republicano Português, monárquicos independentes como Vieira de Almeida Socialistas da SPIO e da União Socialista, comunistas do PCP, anarquistas da CGT, nacionais-sindicalistas de Rolão Preto, democratas cristãos do Grupo Era Nova (como Francisco Veloso (25) e o P. Joaquim Alves Correia). E também nomes de vulto das artes, das letras, do foro, das ciências, da Universidade, das Forças Armadas.

$\mathrm{Na}$ hipótese, que começava a adivinhar-se, de não aceitação de tais condições de participação, é preconizada pelo MUD a abstenção, numa reunião a 10 de Outubro, realizada no Teatro Taborda, o que acabará efectivamente por acontecer.

A 16 de Outubro, o Governo Civil de Lisboa dava a conhecer como resposta do Governo, a decisão de manter as disposições legais respeitantes às candidaturas e sua eligibilidade, de não adiar as eleições, de não alterar as restrições às liberdades e as normas vigentes de fiscalização eleitoral, e de não proceder a novo recenseamento.

Perante o indeferimento das reclamações pelo Governo que assim era comunicado, os representantes do MUD dirigem-se então ao Presidente da República no dia seguinte, véspera do termo do prazo de entrega das candidaturas, para reiterar o pedido de adiamento das eleições, sem o qual se tornava impossível a participação da oposição. Informam então Carmona da persistência da censura, da proibição imposta pela polícia política aos comerciantes de terem nos seus estabelecimentos as listas do MUD para recolha de adesões, etc. Como o Presidente da República tivesse recusado interferir nas resoluções do Governo, o MUD interpõe recurso para o Supremo Tribunal Administrativo para que suspenda o decreto de marcação das eleições. Em comunicado público dá conta da «campanha de boatos e intimidação» que é movida

(25) Sobrinho do dirigente democristão dos finais da Monarquia, Prof. Francisco José de Sousa Gomes, com quem foi educado na infância. 
contra os aderentes, denuncia a ameaça de represálias, o interrogatório a funcionários públicos nalgumas repartições sobre a sua adesão ao MUD e, por fim, a ameaça de devassar o movimento e quem the deu aplauso.

Efectivamente, a 25 de Outubro, o Ministro do Interior anuncia ir proceder a um inquérito às listas de apoio ao MUD, pretextuando querer averiguar da autenticidade das assinaturas anunciadas numericamente. Levado pelo desejo de defender o prestígio moral do movimento, mas também por intimação governativa, o Dr. Lima Alves acaba por entregar ao Governo e, por este, à PIDE, as longas enumerações de opositores com que a polícia política actualizou os seus ficheiros, e que permitiu ao Governo iniciar acções de intimidação e de punição de funcionários públicos por adesão ao MUD. A primeira vítima seria o Ten. Cor. Plínio da Silva, suspenso telegráficamente das funções de comando militar que exercia em Ponta Delgada, e mandado regressar imediatamente ao Continente. O mesmo acontece, apesar dos protestos de ilegitimidade e ilegalidade, noutros pontos do país. Em alguns, porém, como no Porto, a Comissão Distrital do MUD acabaria por recusar-se a fazê-lo sem que previamente fosse garantido que não seriam exercidas represálias sobre os subscritores das listas e sem estarem definidos os casos específicos que, com o inquérito, se pretendiam comprovar. Por essa razão foram presos alguns membros dessa Comissão Distrital, como Rui Luis Gomes, Mário Cal Brandão, António Barros Machado e Olívio França.

Pretendendo porém dar a ideia de uma oposição disciplinada e respeitadora do quadro legal, a Comissão Central do MUD dá instruções para terminarem as sessões de propaganda a partir do dia 27 e até ao dia 10 de Novembro, sem que isso signifique porém que se deixe de trabalhar na organização das comissões locais e na propaganda das reclamações apresentadas. Ordena ainda que se preparem reuniões nas sedes de Distrito, devidamente autorizadas, como encerramento da actuação $\left({ }^{26}\right)$. Efectivamente, tem lugar em Lisboa a 10 de Novembro uma sessão no Teatro Taborda, para apresentação de um relatório de balanço da Comissão Central do MUD. "O movimento procurou por um lado consolidar e desenvolver direitos políticos e por outro arquivar provas da contradição entre as afirmações do Governo e os seus desígnios» $\left({ }^{27}\right)$ disse então Mário de Lima Alves. Propõe-se que o ${ }^{(*)}$

(*) República, 24.X.45.

(27) Seara Nova, n. ${ }^{\circ 52}$, Ano XXV, 10.XI.45. 
movimento continue a lutar pelo adiamento das eleições, pela satisfação de outras reivindicações, que, no caso de não serem atendidas, se defenda a abstenção eleitoral, se alarguem os corpos dirigentes e se continue a melhorar a organização.

Da Comissão Central passaram então a fazer parte Barbosa de Magalhães, Bento de Jesus Caraça, Fernando Mayer Garção, Pedro Pita, Alves Redol, o operário Alberto Dias, e os membros da Comissão Executiva: Lima Alves, Teófilo C. Santos, Manuel Mendes. E uma Comissão Consultiva foi também constituída, integrando entre outros os nomes de Norton de Matos, Duarte Leite, António Luis Gomes, António Sérgio, Lobo Vilela, José Bacelar, Rui Luis Gomes, António Macedo, Carvalhão Duarte, etc. $\left({ }^{2 S}\right)$.

O Governo que considerava o MUD, no dizer do Ministro do Interior, um movimento «heterogéneo», «amálgama sem coesão orgânica, sem espírito de coligação, sem comunidade de interesses, sem objectivo comum a atingir, sem unidade de direcção - massa arregimentada apenas sob o signo da democracia no irreflectido desejo de escala ao Poder»> (29), mantem em relação a ele uma atitude de relativa tolerância. Mas uma entrevista de Armando Cortesão (no exílio) ao Cité-Soir, nos começos de Novembro, em que revelava publicamente a presença de comunistas num Conselho Superior de direcção da resistência portuguesa, cria problemas internos ao MUD e permite às forças situacionistas desencadear sobre ele uma campanha de acusações anti-comunistas.

Isso não impediu, porém, que um programa democrático frentista fosse publicado, preconizando três fases de democratização do Estado: a primeira seria de medidas urgentes de destruição do regime e de defesa do povo; a segunda seria de período eleitoral, para a formação de uma assembleia Constituinte; e a terceira, de normalidade constitucional $\left({ }^{30}\right)$.

No ano seguinte, o MUD, tendo prosseguido as suas actividades dota-se de nova Comissão Central, agora presidida por Mário de Azevedo Gomes, e onde se fazem representar de novo progressistas independentes ligados ao MUNAF, socialistas da Uniẫo, comunistas, velhos republicanos e anarquistas ( $\left.{ }^{\mathrm{S} 1}\right)$. A 6 de Setembro de 1946 a Comissão Central publica um manifesto sobre o veto de admissão de Portugal $\left(^{*}\right.$

(*) República, 11.XI.45.

(“) Diário da Manhã, 15.XI.45.

(30) Diário da Manhã, 15.XI.45.

(31) Mário Soares, Le Portugal Bailloné Témoignage, Paris, Calmann-Levy, 1972, pp. 60-61. 
na ONU onde se afirma que «a admissão de Portugal na comunidade internacional implica a integração do Estado numa ordem democrática para que pudesse tal admissão constituir um direito» $\left({ }^{32}\right)$. Como represália são demitidos das suas cátedras universitárias Mário de Azevedo Gomes e Bento de Jesus Caraça, e são presos e julgados, sob a acusação de traição, todos os signatários.

Isso não impede que no último dia do mês de Novembro desse mesmo ano, se realize na Voz do Operário uma importante reunião pública, destinada a apreciar o momento político e as condiçôes de participação do MUD na vida política. Dela saem, de novo, reivindicações respeitantes à restauração das liberdades fundamentais e à democratização do Estado ( $\left.{ }^{33}\right)$.

No ano seguinte, entre 21 e 28 de Março de 1947, o MUD organiza uma Semana da Juventude. O MUD-Juvenil fora aliás uma importante derivação do movimento. Formado na sequência da reunião do Centro Almirante Reis, pretendeu estender inicialmente as reivindicações de liberalização do movimento à Universidade, nomeadamente com os pedidos de libertação dos estudantes presos, de reintegração dos professores afastados por razões políticas, de eleições livres para as associações académicas, de representação de estudantes nos Conselhos da Faculdade, e de democratização do ensino em geral $\left({ }^{34}\right)$. Mais tarde porém, alargaria as suas actividades para além dos sectores estudantis. A Comissão Central do MUD-Juvenil era presidida por Mário Soares e dela fizeram parte entre outros Salgado Zenha, Júlio Pomar, Rui Grácio, Mário de Sacramento, Octávio Pato.

A proximidade do termo do terceiro mandato presidencial de Carmona levou a oposição a pensar tirar proveito da eleição que se avizinhava, para de novo mobilizar a opinião pública em torno das reivindicações cívicas e políticas de democratização do país, que o MUD vinha agitando numa semiJegalidade até que em Março de 1948 foi oficialmente proibido. O concurso eleitoral permitir-lhe-ia de novo uma actuação legal. Para isso havia pois que encontrar um candidato. Apesar de haver quem desejasse que a escolha recaísse no

(32) «O MUD perante a admissão de Portugal na ONU», Diário da Manhã, 6.IX.46.

(33) Cf. $A$ Sessão de 30 de Novembro de 1946 do MUD, Edição da Comissão Central, MUD, Lisboa, 1946.

(34) Das actividades do MUD estudantil deu conta a respectiva Comissão em relatório publicado em Seara Nova de 6.XI.45. 
presidente da Comissão Central, Mário de Azevedo Gomes como foi o caso de Mário Soares, então representante do MUD Juvenil naquela comissão ( ${ }^{35}$ ) - ou antes num homem descomprometido com o passado da 1 a $^{\text {a }}$ República-como o pretendia António Sérgio, que para isso indicou o nome do Gen. Costa Ferreira ( 36 ) - o candidato escolhido, em Março de $1947\left({ }^{37}\right)$ por indicação da Comissão Distrital do MUD portuense, foi o Gen. Norton de Matos que fora membro do PRP, grão-mestre da maçonaria, ministro da República, Governador Geral de Angola, dirigente da Aliança Republicana-Socialista, presidente do Conselho Nacional do MUNAF e membro da Comissão Consultiva do MUD.

Norton de Matos, que aceitara o convite em Abril de 1948, apresenta publicamente a sua candidatura ao Supremo Tribunal de Justiça a 9 de Julho de 1948 e redige então num manifesto à Nação, as linhas da sua candidatura, que apresenta em conferência de imprensa a 12 desse mês. Sendo uma candidatura da oposição democrática e liberal propõe-se levar a cabo a unidade nacional - unidade territorial, económica e de acção - mediante a valorização e povoamento das Colónias, o reforço da produção agrícola sem deixar de fazer avançar a industrialização, uma «planificação geral» superiormente concebida. Para isso, porém, propõe-se reintegrar o povo num «regime liberal», restituindo-lhe as liberdades fundamentais, reconhecendo o "cidadão» com os seus atributos inamovíveis como base de todo o sistema. Entre as reivindicações imediatas a satisfazer enumera a abolição da polícia política, a extinção de campos de concentração, a amnistia para presos políticos, o regresso dos exilados, a abolição da censura, a liberdade de formação de partidos políticos e novos jornais, a abolição do corporativismo, o fomento cooperativo, a aceitação do princípio da nacionalização desde que imposta pelo bem comum, a reforma do ensino, o alargamento da assistência e segurança sociais, a resolução dos problemas de alimentação e habitação. Se ganhar, promete promover eleições livres para uma Assembleia Constituinte, e uma vez

(35) Mário Soares, ob. cit., pp. 64-65.

(") M. Sertório, "A candidatura de Cunha Leal à Presidência da República», O Jornal, 5.IIL82.

${ }_{(37) \quad A}^{37}$ escolha, segundo ele próprio relata em $O$ s dois primeiros meses da minha candidatura à Presidência da República, Lisboa, Ed. Autor 1948, fora de facto já feita em Março de 1947, e disso lhe foi dado conta quando recebeu felicitações em Ponte de Lima, por ocasião do seu aniversário natalício, em Maio desse ano, de inúmeros representantes da oposição. Mas só em Abril de 1948 aceitaria formalmente a candidatura. 
promulgada a nova constituição, retirar-se-á para que novo Presidente seja eleito.

Avisa porém que aceita concorrer apenas se os actos públicos pré-eleitorais e eleitorais tiverem as características democráticas da liberdade, seriedade e independência. Não se dispõe de facto, a sancionar com o silêncio «nem os vícios da lei, nem as práticas dolosas» que a desrespeitam. De outra forma não serviria a função e o mandato que lhe era entregue.

Colocando-se «sempre escrupulosamente dentro da mais estrita legalidade», Norton de Matos propõe-se democratizar o regime sem para tanto sentir necessidade de sair fora dos limites da Constituição de 1933. «Um dos pressupostos da minha candidatura é permitir ao país, que substitua por outra, se quiser, a actual Constituição» - dizia - nomeando novo Governo para preparar «a eleição inteiramente livre de uma Câmara Constituinte. Para tanto, o Presidente da República não carecerá de saltar fora da Constituição em vigor» ( ${ }^{38}$ ).

Os apoios à candidatura assim expressa vêm de um largo leque de forças democráticas opositoras do regime, mesmo de muitos membros do Directorio do Partido Republicano, previamente contactados pela província. «Homens de diversas crenças religiosas, monárquicos de vários matizes, republicanos de diversos partidos, conservadores, liberais, socialistas e os mais recentes na nossa vida política - os comunistas» assim definiu à imprensa Norton de Matos os seus apoios $\left({ }^{39}\right)$. A parte Cunha Leal, que atacara violentamente a acção de Norton de Matos em Angola, num opúsculo que o regime vai agora usar contra o candidato da oposição - Caligula em Angola era o seu título - , apenas a Comissão Executiva do Partido Republicano era contrária à sua candidatura, porque achava inevitável e necessária a desistência e a abstençấo. Em Abril de 1948 considerava em circular, «inoportuna a apresentação de qualquer candidatura por parte da oposição ao Governo, enquanto este não modificasse a actual lei eleitoral no sentido de se garantir a genuinidade do sufrágio»». Nos começos de 1949, Manuel Serras, secretário geral do partido, reiterará em declarações públicas, a mesma posição: «ou o governo previamente rodeava o acto eleitoral das garantias que a oposição legitimamente reclamava, de forma que esta pudesse decente e seriamente tomar nele parte, ou não o fazia (e como se vê, até agora não o fez) e, nesse caso, a opo-

(38) Norton de Matos, ob. cit. $f$ p. 52.

(39) Idem, p. 36. 
sição não emprestava a sua colaboração, nem mesmo em princípio, a uma comédia destinada a dar fora do país a errada impressão da existência, em Portugal, de uma liberdade que continua praticamente suprimida» $\left({ }^{40}\right)$.

A Comissão Executiva do Partido Republicano, para quem o Governo, com a sua intransigência em não tolerar qualquer mudança para uma situação democrática, estaria a fabricar comunistas todos os dias, estava, de facto, no fundo, bem mais empenhada em fazer o que chamava, na sua mensagem de Ano Novo de 1949, «oposição construtiva», disposição essa que encontrava aliás nas hostes republicanas do regime eco favorável. Botelho Moniz, por exemplo, defenderia, em plena campanha eleitoral, aos microfones do Rádio Clube Português: a amnistia; o abrandamento da censura; maior liberdade de reunião; liberdade de agremiações da oposição, para dar maior vitalidade e combatividade à União Nacional, e para que a oposição fiscalize e critique na Assembleia Nacional; mas também, repressão ao comunismo; isto é, um alargamento do consenso, com abertura a uma oposição colaborante e participante $\left({ }^{41}\right)$.

$\mathrm{Na}$ realidade, as garantias de uma campanha livre estavam longe de estar estabelecidas. O primeiro indício teve-o Norton de Matos quando, a 19 de Agosto de 1948, chamou a sua casa dez amigos para lhes apresentar uma proposta de organização dos serviços da sua candidatura. A polícia cercou a casa, e prendeu os que dela sairam, só vindo a ser libertados por pressão de Norton de Matos junto de Salazar $\left({ }^{42}\right)$.

Dias depois, a 8 de Setembro de 1948, Norton de Matos escrevia a Salazar para protestar contra os «vexames, as violências, e principalmente a privação de direitos, de regalias, de respeito» por parte das autoridades administrativas e policiais; contra o «regime policial de excepção» em que fora colocado, «como se se tratasse de um criminoso»; e exigia que pudesse dar início à sua propaganda eleitoral (43). A 23 desse mês era informado pelo Presidente do Conselho do equívoco «em se considerar já candidato à Presidência da República», e em pretender por isso «direitos especiais» ou «ini-

(40) Diário de Lisboa, 4 de Janeiro de 1949.

(41) Botelho Moniz, Campanha Eleitoral (palestras radiofónicas), Lisboa Parceria A. Maria Pereira, 1949, p. 158-160.

(42) Norton de Matos, ob. cit., pp. 63-65.

D Idem, p. 69. 
ciado o período eleitoral» $\left({ }^{44}\right)$, já que a candidatura fora apresentada ao Supremo Tribunal de Justiça, mas este não se pronunciara ainda sobre ela.

A 29 de Setembro desse ano enviava Norton de Matos ao Presidente da República uma representação para que «a eleição presidencial se realize num ambiente de grande elevação civica», solicitando para esse efeito uma amnistia para os presos políticos, a abolição da polícia política, a supressão completa de maus tratos a prisioneiros, o encerramento do Campo do Tarrafal, a possibilidade de criar e fazer circular novos jornais, a cessação da censura, a liberdade de organização e actuação de partidos políticos (45). Tais reivindicações voltarão a ser apresentadas por Norton de Matos a Carmona a 22 de Dezembro desse mesmo ano $\left({ }^{46}\right)$. E a 9 de Outubro, avisa Salazar em carta, de que se as eleições não forem livres e fiscalizadas «grande mal fatalmente resultará para Portugal em consequência do desprestígio e da desconsideração que lhe acarretarão eleições sem liberdade e sem fiscalização», e que contra isso protestará formalmente (46a).

Quando os delegados das Comissões de Serviços Distritais de Candidatura $\left({ }^{47}\right)$ se reuniram em assembleia nacional a 30 de Dezembro de 1948, para preparar a Campanha Eleitoral que ia iniciar-se, confrontaram-se já com uma constatação lesiva da liberdade eleitoral: o corte «indevido e abusivo» $\left({ }^{48}\right)$ de milhares de nomes no recenseamento eleitoral entre os quais os de inúmeros vultos da oposição, tais como os de Prof. Fernando da Fonseca, Alves Redol, Lopes Graça, Acácio de Gouveia, Adão e Silva, Rui Luis Gomes, Domingos Pereira, etc. $\left({ }^{49}\right)$. Por isso Norton de Matos dirige de novo a Salazar, a 31 de Dezembro, uma exposição em que fixa o mínimo de reclamações pré*eleitorais e eleitorais a serem satisfeitas, entre as quais a consulta dos cadernos eleitorais e a fiscalização isenta das eleições. E avisa solenemente: «Não me prestarei a colaborar numa farsa eleitoral e deixarei ao Governo a responsabilidade de manifestar a todo o mundo que em Portugal não há eleições livres, só podendo votar e

(44) Norton de Matos, Mais quatro meses da minha candidatura à Presidência da República, Porto, Ed. do Autor, 1949, p. 38.

(45) Idem, p. 75

I46) Idem, p. 90.

(46a) Idem, p. 85.

$\left({ }^{4 T}\right)$ Sobre a organização dos serviços de candidatura cf. Norton de Matos, Os dois primeiros meses..., pp. 115-121.

(48) Diário de Lisboa, 3.1.49.

(49) Norton de Matos, Os dois primeiros meses..., p. 27. 
ser eleitor aqueles que, em sua soberana vontade, ele quiser» $\left({ }^{50}\right)$.

Dessa exposição manda também cópia a Carmona, pedindo-lhe que interviesse na boa solução dessas exigências: «Considera que a dignidade de nós dois, como cidadãos portugueses e candidatos à Presidência da República, está igualmente envolvida no deferimento [das reclamações apresentadas ao Presidente do Conselho]» (51).

Mas mal começada a campanha eleitoral, a 1 de Janeiro de 1949 , verifica-se que a censura à imprensa e à propaganda eleitoral não desaparecera, antes continuava a cercear a liberdade de actuação da oposição. «Os serviços de Censura haviam dado instruções aos jornais para que lhes fosse submetida toda a matéria que diz respeito ao acto eleitoral» $\left({ }^{52}\right)$. Norton de Matos denuncia-o na Conferência de Imprensa, de abertura da campanha, a 3 de Janeiro de 1949 em que saúda o povo português como «candidato dos liberais e democratas», desejando-lhe o que solicitara por duas vezes já ao Presidente da República: amnistia para presos políticos com o desaparecimento do campo de concentração do Tarrafal e o restabelecimento das liberdades públicas.

Denuncia publicamente a censura prévia à sua propaganda na imprensa, reivindica igualdade de tratamento para os dois candidatos quando lhe negam a possibilidade de realizar manifestações de rua, exige a revisão da lei eleitoral e dos processos de fiscalização, denuncia os vícios do recenseamento e a abusiva intromissão da União Nacional na elaboração dos cadernos, explicita as suas acusações de violação dos direitos humanos por parte do regime no tratamento de exilados, deportados e perseguidos $\left({ }^{53}\right)$.

De facto acontecia que as intromissões da censura eram constantes; a polícia política apreendia documentos de candidatura, procedia a buscas domiciliárias, e interrogava representantes da oposição; as autoridades proibiam o uso de alti-falantes à oposição, enquanto a União Nacional dispunha à vontade dos microfones da Emissora Nacional. As manifesmeses..., p. 95.

(50) Diário de Lisboa, 3.1.49 e Norton de Matos, Mais quatro

(51) Norton de Matos, À Nação, Edição dos Serviços Centrais de Candidatura, Lisboa, 1949, p. 8; Diário de Lisboa, 3.1.49 e Norton de Matos, Mais quatro meses..., p. 102.

(52) República, 5.1.49. Lisboa, 3.1.49.

C53) «Conferência de Imprensa de Norton de Matos», Diário de 
tações públicas, mesmo as comemorativas como as de 31 de Janeiro, foram proibidas.

Oposicionistas houve que foram presos, ou por serem acusados de serem comunistas ou por declarações políticas prestadas à imprensa, como foi o caso do Prof. Rodrigues Lapa que foi objecto de mandato de captura e vítima de procedimento criminal por ter feito considerações sobre a recusa da entrada de Portugal na ONU. O Ministro da Justiça justificava tais procedimentos afirmando, no início da campanha eleitoral, que a crítica ao regime apenas se aceitava se feita «com elevação, com espírito construtivo, sem características dissolventes». A censura era, por isso, aconselhável; a propaganda não deveria realizar-se «na via pública» para que a ordem não fosse perturbada; e negava a existência de exilados e presos políticos, para admitir apenas presos por alta traição e terrorismo $\left({ }^{54}\right)$.

Com o aproximar-se da data das eleições, como não fossem satisfeitas as exigências postas para a fiscalização do acto eleitoral, nomeadamente as que Norton de Matos apresentara sucessivas vezes ao Governo em relação à consulta dos cadernos eleitorais e aos «delegados eleitorais, seus direitos, e garantias insofismáveis» ( ${ }^{55}$ ) a oposição ameaça desistir. E a 12 de Fevereiro, véspera do dia das eleições, Norton de Matos anuncia publicamente a desistência, que apresenta em requerimento ao Supremo Tribunal da Justiça ${ }^{56}$ ). Salazar, cinicamente, responde a Norton de Matos que não o pode ajudar a ganhar as eleições.

A campanha de Norton de Matos reunira em torno de um velho liberal que se propunha «levantar as classes trabalhadoras e diminuir o mais possível a miséria» $\left({ }^{57}\right)$ a quase totalidade da oposição, excepção feita para alguns nomes de vulto, como os de Cunha Leal e de alguns membros da Comissão Executiva do Partido Republicano.

(54) Diário da Manhã, 5 de Janeiro 1949.

(55) Cf. Comunicado à Imprensa da Candidatura de Norton de Matos sobre "A consulta dos Cadernos Eleitorais» in As eleições no regime fascista Lx., Presidência do Conselho de Ministros, Comissão do Livro Negro sobre o fascismo, 1979.

(56) Em resposta ao requerimento de Norton de Matos, o Presidente do Supremo Tribunal exarou um despacho onde o considera fora da competência do Tribunal, apenas limitada ao «reconhecimento da elegibilidade dos candidatos, elegibilidade que não é renunciável, e ao agrupamento final de votos a favor dos candidatos reconhecidos elegíveis» (Cf. Arquivo do Ministério do Interior).

$\mathrm{C}^{57}$ ) Norton de Matos, $\boldsymbol{A}$ Nação, p. 18. 
Cunha Leal acusara os comunistas de, num golpe de antecipação, terem feito arrancar a candidatura do velho general (58). A presença dos comunistas fora discutida de facto no seio da candidatura, havendo quem pretendesse a sua subalternidade ou até marginalização. O próprio Partido Comunista atacou violentamente na sua imprensa clandestina nomes como os de Nuno Simões, Cunha Leal, Lima Alves, António Sérgio, Ramada Curto, José de Sousa, acusando-os como «desagregadores, divisionistas, sabotadores, oportunistas e traidores», como «agentes, mais ou menos camuflados, do salazarismo, dos imperialistas anglo-americanos, e até do Vaticano» ${ }^{(59)}$. Norton de Matos teria que ocupar-se forçosamente da questão do apoio comunista à sua candidatura. Falando no Comício do Porto, começou por recusar a acusação de que a oposição ao regime seria apenas composta por comunistas, para lembrar de seguida que o objectivo da sua campanha era apenas o derrube do regime e que, para tal objectivo, poderiam colaborar também os comunistas, que considerou «portugueses e patriotas, como todos os outros meus companheiros nesta formidável luta». Mas, como liberal, acrescentou - num clara referência ao comunismo - estar convencido que «a melhor maneira de fazer desaparecer ideologias que não vejo forma de se adaptarem à mentalidade e às tradições históricas do Povo Português, é a liberdade, a ampla discussão dos diversos problemas políticos, económicos e sociais, sempre feita à clara luz do dia, o melhoramento das condições de vida do nosso Povo, e o combate constante à miséria de qualquer espécie» $\left({ }^{60}\right)$.

Esta unidade da oposição que em termos sociais associava pessoas de vária extracção profisssional e de diversa posição ideológica - no dizer de Norton de Matos $\left({ }^{61}\right)$ - feita em torno de um objectivo tão simples quanto concreto, como era o derrube do regime, cedo se rompeu após o termo da campanha eleitoral. As tensões no interior da candidatura, em relação à posição a tomar face ao acto eleitoral - desistência ou participação —o mesmo era dizer face ao regime haviam já minado a unidade em torno de Norton de Matos.

Não admira pois que, encerrada a campanha eleitoral para a PR, a oposição se viesse a dividir em duas grandes tendências: por um lado um sector que integrava o PCP, e

(58) Diário de Lisboa, 22.1.49.

(50) Cf. J. Botelho Moniz, ob. cit., pp. 113 e ss.

(68) Diário de Lisboa, 23.1.49.

(61) Norton de Matos, Os dois primeiros meses..., pp. 28-29. 
era por ele liderada, que viria a corporizar-se no Movimento Nacional Democrático, nesse ano de 1949, que será extinto em 1956, e terá considerável expressão nas eleições de 1957; e por outro lado, o sector liderado pelo Directorio Democrático Social ou Comissão dos 24 (tal era o número dos assinantes de um documento então divulgado).

A oposição, desunida a partir de então, assim permanecerá dividida até às eleições presidenciais de 1958, quando então se congregou de novo à volta da figura do General Humberto Delgado.

\section{A oposição dividida: abstencionismo versus intervencio- nismo (1949-1957)}

A disputa entre abstencionismo e intervencionismo no seio da oposição, manifestara-se já como vimos no decurso da campanha de Norton de Matos. Ao abstencionismo por princípio da C. Executiva do PRP, associara-se o intervencionismo táctico do MUD, também defendido pelo PCP, e partilhado pela maioria dos apoiantes do General, e também o intervencionismo até ao fim do PSP, que nesse sentido tentou pressionar todo o movimento de candidatura com um comunicado emitido a 5 de Fevereiro de 1949 (62) e que parecia ter sido partilhado pelo próprio Norton de Matos $\left({ }^{6 \mathrm{~S}}\right)$.

Com a proximidade das novas eleições — as legislativas de 49 - o diferendo estratégico vai agravar-se no seio da Oposição e dividi-la.

No entanto, a polémica em torno do problema da intervenção eleitoral mais não é do que um aspecto da questão bem mais funda da estratégia de luta para o derrube do regime e do posicionamento perante ele, bem como da luta interna pela hegemonia da oposição ao Estado Novo.

Curiosamente como veremos, o abstencionismo e o intervencionismo não serão sequer apanágio permanente das mesmas correntes da oposição, que abraçarão ora uma ou outra das duas posições, consoante as conveniências tácticas do momento, em função dessas mais profundas questões que apontámos. Os que em 1949 e 1953 aparecerão como intervencionistas estarão em 1957 como abstencionistas, enquanto que os abstencionistas das duas primeiras datas surgirão como intervencionistas na última.

(\#2) Botelho Moniz, ob. cit., p. 282.

(“) M. Soares, ob. cit., p. 71. 


\section{António Sérgio}

A oposição saira em discussão da campanha eleitoral de Norton de Matos. Questões de estratégia política - como a participação eleitoral e a participação comunista - dividiram sectores até então unidos. A assinatura por Portugal do Tratado do Atlântico Norte em Abril de 1949, e o desencadear da «guerra fria» a nível internacional, mais agudizaram a fractura da oposição. De um lado os democratas atlantistas que, defendendo o alinhamento político de Portugal com os países da NATO procuravam forçar Salazar à democratização interna. De outro lado, os anti-atlantistas, para quem a assinatura do Tratado de Washington, reforçaria e consolidaria interna e externamente o regime. Entre estes, os comunistas que nessa primavera viam presos os seus máximos dirigentes Álvaro Cunhal e Militão Ribeiro e desmantelado o aparelho tipográfico clandestino do Partido.

Com a ocorrência das eleições para a AN em Novembro desse mesmo ano de 1949, esta clivagem vai começar a manifestar-se publicamente. Cunha Leal, membro proeminente da facção liberal-democrata da oposição, que não pertencera ao MUD e se mantivera afastado na campanha de Norton de Matos, decide entrar na luta eleitoral, para ir até ao fim. Considerando que fora um erro de manobra eleitoral a aliança com os comunistas, em 1945, e a sujeição à sua direcção de alguns democratas, que se traduzira numa irredutibilidade de posições perante o regime, preconiza antes uma «oposição construtiva»». E alia-se, para esse efeito, aos sectores mais conservadores da oposiçã̃o, a um grupo de grandes agricultores da Beira-Alta e do Alto-Alentejo, alguns dos quais ligados ao extinto Integralismo Lusitano. Surgem assim duas listas «regionalistas independentes» em oposição às da União Nacional, em Castelo Branco e Portalgre. A primeira, encabeçada por Cunha Leal, integrava os nomes do Marquês da Graciosa (Fernando Afonso Pereira de Figueiredo), Almeida Garrett, e do integralista P. Ribeiro Cardoso. A segunda era liderada por José Pequito Rebelo e integrava os nomes de Dr. André de Mello Castro Ribeiro, Dr. Jorge da Fonseca Bastos e Eng. ${ }^{\circ}$ Agr. ${ }^{\circ}$ João Picão Caldeira.

Enquanto Cunha Leal se apresenta na Beira Baixa a fazer decididamente mais oposição ao governo do que ao regime, criticando sobretudo a acção governativa nas suas incidências locais, de que o Manifesto à Nação e ao Governo, e a conferência na Covilhã sobre «Razões e objectives da candidatura» são testemunho, Pequito Rebelo, no Alto Alentejo, frisa bem que a «a lista de que faço parte não pretende ser de oposição, mas simplesmente representativa da opinião do eleitorado, livre da perturbação de quaisquer abusivas in- 
fluências políticas», ou melhor, «essencialmente construtiva e colaboracionista» $\left({ }^{64}\right)$.

Como reacção à débil representação dos interesses agrícolas da região nas listas da União Nacional, e à «formação anómola, patológica», da Assembleia Nacional, "como expressão do monopólio político da Burocracia», é uma lista de proprietários agrícolas, que visa reduzir na mesma assembleia «o seu carácter unilateral de sindicato da indústria do emprego público» $\left({ }^{65}\right)$.

O móbil desta última candidatura estava precisamente na insatisfação pela exígua representatividade na lista local da União Nacional não só dos interesses da grande lavoura, como da opinião monárquica. $\mathrm{O}$ próprio Pequito Rebelo recusara a inclusão do seu nome, superiormente desejada, na lista da União Nacional. «A lista da União Nacional - diria após a eleição o jornal Rabeca de Portalegre - triunfou com clareza e teve um apoio mais substancial da oposição republicana democrática, certamente por ser constituída por indivíduos de feição republicana, ao contrário da «agrária» formada por elementos confessadamente monárquicos» $\left({ }^{66}\right)$.

O Movimento Nacional Democrático, presidido por Rui Luis Gomes, mantém-se numa posição abstencionista, desinteressando se de todo do acto eleitoral.

Não foi fácil a campanha para estas listas regionalistas que, sobretudo no caso de Portalegre, chegaram a acusar o Governo de ter viciado o acto eleitoral e a pedir a anulação da eleição. Pequito Rebelo em telegrama a Salazar, denunciaria a violação do segredo de voto, com a impressão de listas em papéis diferenciáveis, a coacção moral sobre o eleitorado com a "execução apressada de benefícios públicos e promessas oficiais e oficiosas», a limitação de liberdade pela censura, e as suspeitas de falsificações dos resultados por insuficiente fiscalização $\left({ }^{67}\right)$.

As listas de oposição vão de facto até às umas pela primeira vez, não conseguindo porém mais do que 964 votos em Castelo Branco $(2,45 \%)$ e 3.642 em Portalegre $(14,39 \%)$.

A morte de Carmona e a realização de novas eleições presidenciais, em 1951, surpreende a oposição profundamente dividida. O Movimento Nacional Democrático resolve apresentar a candidatura do seu presidente Rui Luis Gomes, en-

\footnotetext{
$\left.\mathrm{C}^{64}\right)$ Pequito Rebelo, As eleições de Portalegre (Documentos), Lisboa 1950, p. 39.

(65) Idem, p. 38.

(66) Citado por Pequito Rebelo, ob. cit., p. 37.

$\left.C^{1}\right)$ Pequito Rebelo, ob. cit., p. 37.
} 
quanto os sectores mais liberais próximos do Directorio optam pela candidatura do Almirante Quintão Meireles, militar na reserva que fora membro de um governo da Ditadura saída do 28 de Maio mas, mais tarde, se viria a afastar do regime.

Como o próprio Quintão Meireles o explicou, a abrir o seu Manifesto ao País, «partiram de um grupo de oficiais e alguns civis, fundadores, animadores, e parcitipantes do movimento do 28 de Maio de 1926, e depois defensores da situação criada, em momentos críticos da sua existência (Fevereiro de 1927, Agosto de 1931, etc.) (68), a ideia e o convite que, por fim, determinaram a apresentação da minha candidatura» $\left({ }^{69}\right)$. A candidatura colocava-se na linha de crítica à 1. ${ }^{a}$ República e ao Estado Novo, contra o partido único «de facto» da primeira e o partido único «de direito» da segunda, reivindicando a pureza dos ideais do 28 de Maio, os quais seriam o derrube do poder descricionário, a eliminação dos desmandos de administração e de distribuição injustificável de benesses, o ataque à corrupção, que agora como então proliferariam. Mais: a candidatura invocava «os mais sagrados interesses do País como nação compreendida no quadro ocidental de civilização europeia»» $\left({ }^{70}\right)$.

Era, por conseguinte, uma candidatura de correcção do regime destinada a permitir a aproximação de alguns sectores da situação interna com uma certa oposição externa, liberal, republicana e democrata, e da qual seria obviamente excluído qualquer compromisso ou entendimento com o Partido Comunista e forcas que com ele colaborassem. Não era por certo uma candidatura de oposição ao regime, visando o seu imediato derrube procurando para isso, o mais vasto leque possível de apoios como o fora a de Norton de Matos. Expressão da Guerra Fria no seio da oposição ao salazarismo, era também a manifestação de uma nova táctica, de ataque ao regime, enquanto regime de partido único. Propondo-se a pacificação e unificação dos portugueses «em torno do ideal da Pátria», Quintão Meireles excluía porém expressamente dessa ideia de nacionalismo os «totalitaristas, comunistas ou anti-comunistas, que obedecem à inspiração e directivas de uma potência estrangeira ou que pelos seus métodos despóticos prepararam a passividade das massas para o mesmo fim».

Não enjeita alguns elogios ao regime, nomeadamente em matéria de reorganização financeira e reconstrução material,

(") Levantamentos militares contra a Ditadura.

C) República, 4.VII.51.

(T) Idem. 
para o criticar porém politicamente, pela destruição das liberdades políticas e do civismo, e pela difusão do arbítrio do poder, da corrupção, da censura. $O$ primeiro ponto do seu programa era o de «acatar e fazer cumprir a Constituição da República Portuguesa vigente, repudiando o recurso a sofismas que, de alguma forma, a deturpem ou viciem». Era por conseguinte, uma candidatura que procurava não só mover-se dentro da legalidade vigente, como até acatar a legitimidade do regime.

Tal como se posicionou Quintão Meireles, em carta aberta a Craveiro Lopes, ele não seria mesmo um adversário do regime, mas antes um rectificador. Referindo-se às candidaturas de ambos, precisava: «Não se trata, por um lado, de uma contenda entre partidários e adversários da actual situação política. O que explica o aparecimento das nossas duas candidaturas é a existência, dentro do situacionismo, de duas correntes de opinião - a dos homens que fizeram o «28 de Maio», com o objectivo de destruir o monopólio do poder por um partido único, de tomar eficiente e moral a actividade governativa e de elevar o baixo nível material e espiritual da vida portuguesa, e a dos homens que, aproveitando-se da isenção dos primeiros, se alcandoraram no poder e acabaram por deturpar, e mesmo inverter, as intenções iniciais do «28 de Maio»» ${ }^{71}$ ).

Nesse sentido se explicam as instruções dadas pelos serviços de candidatura, no sentido de o eleitorado que o apoia se abster «de ataques pessoais subjectivos, de empregar expressões que ofendam a dignidade dos candidatos contrários, de rasgar ou inutilizar os impressos de propaganda da União Nacional e da Legião Portuguesa, de escrever frases ofensivas nas paredes ou nos pavimentos das ruas - enfim de todas as actividades que, de alguma forma, sacrifiquem o alto exemplo da ordem, elevação, serenidade e consciência de força que vamos dar ao País e às forças minoritárias adversas» $\left({ }^{72}\right)$.

A apoiar esta candidatura surgem efectivamente, ao lado de eminentes personalidades dos sectores liberais-democratas e até socialistas da oposição, alguns monárquicos dissidentes, nomes ligados ao 28 de Maio e, até há pouco, alinhados com o regime. Assim, ao lado de Egas Moniz (recém galardoado com o Prémio Nobel da Medicina ( ${ }^{73}$ ) e que fora, por indicação

(n) República, 7 de Julho de 1951.

(72) República, 7 de Julho de 1951. Outubro de 1949.

(73) O prémio Nobel fora-lhe atribuído efectivamente a 27 de 
de Norton de Matos, o primeiro a ser convidado a aceitar a candidatura), de Cunha Leal, Acácio Gouveia, Teófilo Carvalho dos Santos, Vasco da Gama Fernandes e António Sérgio, entre outros, surgem os nomes de Rolão Preto, Alcaça Padez, Vieira de Almeida, Almeida Braga, Vasco de Carvalho e Mário Pessoa, e ainda militares prestigiados, alguns dos quais com passado ligado à Ditadura ou ao regime, como Mendes Cabeçadas, Sousa Dias, Henrique Galvão $\left({ }^{74}\right)$, Com. ${ }^{\text {te }}$ Azevedo Coutinho, etc. O Partido Republicano, mau grado as críticas proferidas por Quintão Meireles à 1. ${ }^{\mathrm{a}}$ República e ao próprio partido, acabaria também por dar-lhe a sua indicação de voto.

A candidatura de Rui Luis Gomes era manifestamente diversa, porque candidatura de oposição ao regime. Nesse sentido, afirma-se continuadora do MUD e da candidatura de Norton de Matos, não porque tivesse o apoio do velho general republicano (que estava antes com Quintão Meireles), mas porque pretendia herdar e continuar a mesma estratégia frontal e frentista de oposição ao Estado Novo (75), sem porém conseguir a mesma largueza de apoios. Surgem de facto apenas a apoiar o professor nortenho os seus pares do Movimento Nacional Democrático, (cuja Comissão Central era composta por ele próprio e por Virgínia Moura, Albertino Macedo, José Morgado, Lobão Vital, David Carvalho, Salomão Figueiredo, Júlio Martins e Fernando Cipriano) e algumas figuras proeminentes do extinto MUD, como Isabel Aboim Inglês, Cal Brandão, Tito de Morais. Os sectores republicanos, liberais e alguns socialistas, da candidatura de Norton de Matos, estavam agora com a candidatura de Quintão Meireles.

O apoio e a hegemonia do Partido Comunista no Movimento Nacional Democrático e, por ele, na candidatura de Rui Luis Gomes $\left({ }^{76}\right)$, bloqueava o alargamento das adesões, e motivara por isso desde logo uma peremptória demarcação denunciadora da candidatura de Quintão Meireles: «Não há,

$\left.{ }^{74}\right)$ Henrique Galvão participará, pouco depois, na conjura militar do Brigadeiro Maia e dos Coronéis Martins dos Reis e Tadeu, que a polícia neutralizará no dia 8 de Janeiro de 1952. Por esse facto, será julgado e condenado, em 31 de Março de 1953, a 3 anos de prisão maior.

(75) Os objectivos das reivindicações da candidatura eram condensados em três palavras de ordem: «República e Liberdade»; «Pão e Trabalho»; "Independência Nacional e Paz», e largamente expostos num manifesto Ao Povo, de 8 de Junho de 1951 (in Eleições Presidenciais 1951, Presidência do Conselho de Ministros. Comissão do Livro Negro sobre o Regime Fascista, 1983, pp. 11-17).

(76) Segundo certa imprensa brasileira, o PCP teria apoiado Rui Luis Gomes depois de haver recusado as candidaturas do Prof. Barbosa de Magalhães, e dos Drs. Domingos Pereira e Manuel Monteiro (cf. Diário da Manhã, 2 de Agosto de 1951). 
nem haverá, não se criaram, não se esperam, não se desejam - dizia o Almirante - quaisquer entendimentos, ligações ou formas de «aparentamento» com o grupo que propõe a candidatura do Prof. Dr. Rui Luis Gomes ou com quaisquer grupos ou partidos cuja acção se encontra directa ou indirectamente na dependência de uma potência estrangeira» $\left({ }^{77}\right)$.

O Movimento Nacional Democrático, uma vez constatada a impossibilidade de unidade de acção com a candidatura de Quintão Meireles, procura disputar-lhe os apoios, acusando-a de ser mais uma candidatura dissidente do regime do que uma candidatura da Oposição, «uma cisão no campo governamental e não no movimento democrático», como se disse num comício em Santarém, onde Quintão Meireles foi particularmente acusado: "Nada existe que o identifique com a democracia, porque ele foi um colaboracionista».

A divisão da oposição tornou-a obviamente vulnerável aos ataques do regime, que começou por atingir o MND, neutralizando depois a candidatura de Quintão Meireles. A 13 de Junho, o Supremo Tribunal de Justiça rejeitava a candidatura de Rui Luis Gomes, considerando-o politicamente ineligível. Pouco depois, a censura e a discriminação administrativa iam tomar inviável a campanha de Quintão Meireles.

A 7 de Julho, em carta aberta a Craveiro Lopes $\left({ }^{78}\right)$, de militar para militar, de candidato para candidato, Quintão Meireles convida-o a recusar a «fraude eleitoral» ou as «indecorosas inibições opostas à livre manifestação da vontade nacional» avisando-o de que, "escolhido pela União Nacional como seu candidato, vai beneficiar, e está beneficiando dos favores do Estado». Por isso entende ser seu direito e dever «reclamar dos poderes públicos absoluta honestidade eleitoral, para o que devemos ser postos em condições de igualdade no tocante a propaganda e a físcalização das urnas», devendo «abster-se os órgãos do Estado de quaisquer coacções ou intervenções tendentes a impedir a liberdade do voto».

Não era porém isso o que estava a acontecer, como o comprovam as acusações que Quintão Meireles apresenta numa carta ao Ministro do Interior $\left({ }^{79}\right)$ :

«1) Os cadernos eleitorais foram organizados com o propósito de eliminação de eleitores não incondicionais, ao mesmo tempo que se introduziram ne-

(") República, 2 de Julho de 1951; Diário da Manhã, 4 de Julho de 1951.

$(78)$ República, 7.VIL51.

(79) República, 14.VII.51. 
les os nomes dos indivíduos dos dois sexos, adictos à ordem política existente, mas sem direito a voto.

2) Não se tem dado aos candidatos, sem a chancela da União Nacional, o direito da fiscalização das mesas das Assembleias primárias e apuramento de eleições.

3) Tem-se procurado violar o segredo do voto pelo emprego das listas fabricadas em papel especial, que as torne identificáveis exteriormente, tendo sucedido assim nas últimas eleições para a Assembleia Legislativa nos distritos de Castelo Branco e Portalegre.

4) As autoridades administrativas têm feito uma política de intimidação e suborno tanto de indivíduos como de localidades recalcitrantes ou indecisos»».

Perante tais condições ,não restam a Quintão Meireles, na esteira de outras candidaturas anteriores, outras hipóteses além da abstenção. Depois de um último grande comício em Lisboa, realizado a 16 de Julho na Garagem Monumental do Areeiro, Quintão Meireles anuncia a 19 de Julho em «Manifesto» ao país, a sua decisão de renúncia, dada a «impossibilidade de lutar por mais tempo em terreno desigual» e por considerar «um atentado à inteligência, à moral política e à dignidade cívica, persistir por mais tempo no propósito de colaborar num simulacro de eleição presidencial» $\left({ }^{80}\right)$. No mesmo dia, comunica a decisão também a Salazar, avisando-o que «o Presidente da República será nomeado por mera formalidade eleitoral. Não posso colaborar, pois, no acto que se prepara e menos emprestar-lhe, com a minha colaboração, visos de aparente legitimidade» ( $\left.{ }^{\mathrm{S} 1}\right)$.

A oposição, politicamente dividida, fora assim de novo eleitoralmente neutralizada.

As eleições legislativas de 1953 e 1957 vão porém agitar de novo a oposição que, embora permanecendo dividida, inverterá curiosamente os comportamentos eleitorais: os intervencionistas de 1953 defenderão a abstenção em 1957, enquanto os abstencionistas de 1953 intervirão em 1957.

A constante e permanente ausência de condições de equidade política, que até aí levara a oposição a desistir em 1945, em 1949 e em 1951, vai porém provocar, nas eleições subse-

n República, 20.VII.51.

(") Idem. 
quentes de 1953 e 1957, o aparecimento de uma força cívica, ao lado das duas facções da oposição: a Comissão Promotora do Voto, dirigida por António Sérgio, disposta, não tanto a participar na luta eleitoral, mas a exigir condições dignas de participação.

Foi, de facto, na primavera de 1953, longe ainda da data das eleições, que a recém-constituída Comissão Promotora do Voto começou, através de uma exposição ao Presidente da República com 72 assinaturas ${ }^{82}$ ) e mais tarde por várias representações ao Ministro da Presidência ( ${ }^{83}$ ), a exigir garantias quanto ao recenseamento eleitoral e às operações do acto eleitoral. A saber: compromisso do Governo em não consentir perseguições por motivo de actividades eleitorais; em fornecer meios de verificação do recenseamento; em não dificultar pela censura a propaganda eleitoral; em não impedir a cedência de salas para a realização de sessões; em facultar o uso de emissoras a todos os candidatos por igual; em garantir, em termos de rigorosa paridade, a impressão e distribuição das listas concorrentes; em permitir uma fiscalização pelos candidatos ou seus representantes das umas e do apuramento dos resultados.

Perante o compromisso dado pelo Governo de cumprimento escrupuloso da Constituição convenceu-se um sector da oposição de que algo se havia conseguido nas matérias objecto de reivindicação, e decidiu-se por isso a concorrer. Três listas surgem em Lisboa, Porto e Aveiro, compostas por oposicionistas próximos do Directorio Democrático-Social $\left({ }^{84}\right)$. O objectivo da participação, definem-no os candidatos de Lisboa no primeiro Manifesto: «despertar a consciência cívica

(82) Diário de Lisboa, 15 de Maio de 1953.

(®) Estas representações eram apenas assinadas por um grupo de representantes dos 72, composto por António Sérgio, Manuel Duarte, Luis Moitinho de Almeida, João Pedro dos Santos, Armando Adão e Silva, Nuno Rodrigues dos Santos, Fernando Mayer Garção.

$\mathrm{C}^{84}$ ) Eram assim compostas as listas: LISBOA: Mendes Cabeçadas, Cunha Leal, Moreira de Campos, Nuno Rodrigues dos Santos, Vasco da Gama Fernandes, Acácio Gouveia, Sá Cardoso, Fernando Mayer Garção, Constantino Fernandes, Adão e Silva, Câmara Reis, António Rodrigues Direito; PORTO: António Macedo, Carlos Cal Brandão, Eduardo Ralha, Olívio França, Luis Veiga, Eurico Felgueiras, J. Correia Guimarães, Júlio Semedo, Cardoso Junior, Sousa Pereira; AVEIRO: Manuel Figueiredo, Manuel das Neves, Alcides Monteiro, Alberto Vidal, Basilio Lopes Pereira, Virgílio Pereira da Silva. 
dos cidadãos, vitalizar o corpo político que é a Nação, combater a indiferença e o medo, a apatia e a deserção, e levar o povo a construir ele próprio, revivendo as virtudes ancestrais, a obra democrática que se impõe». Para isso, prometem, através de «luta legal», exigir em $1 .^{\circ}$ lugar a consulta dos cadernos eleitorais para denunciar as fraudes e irregularidades que se venham a encontrar no recenseamento. E como programa de actuação, propõem-se defender os direitos humanos, protestando contra as prepotências do poder e os abusos da administração, contra a existência da censura e da polícia política, da Legião e da Mocidade, das prisões políticas e das perseguições e demissão de funcionários, bem como denunciar o «funcionamento deficiente ou economicamente errado da máquina administrativa». Sintetizaram por fim o seu esforço em dois objectivos: «a luta pela conquista das liberdades fundamentais», e a «luta pela conquista das condições de vida que verdadeiramente o inclui entre os povos civilizados da terra» $\left({ }^{85}\right)$.

A estes objectivos, os candidatos do Porto acrescentam no seu manifesto um outro: «Reclamamos o direito de nos organizarmos permanentemente e termos jus à vida política, não nestas estranhas quaresmas eleitorais que antecedem o carnaval do voto, mas durante os quatro anos que entremeiam duas legislaturas» $\left({ }^{86}\right)$. Idênticos propósitos são também expressos pelos candidatos de Aveiro no seu manifesto.

Perante tal apresentação, o MND vem não só $\left({ }^{87}\right)$ defender a abstenção, pelo facto de não estarem satisfeitas as condições mínimas de participação — «recenseamento honesto, liberdade de propaganda, fiscalização do acto eleitoral» - como atacar duramente a ocorrida apresentação de listas, que não considera serem da oposição democrática, mas antes um acto de colaboração com o actual regime e de abdicação relativamente às reivindicações da Oposição Democrática portuguesa, sempre formuladas desde 1945». Em vez disso, preconiza a luta pela satisfação das condições mínimas $\left({ }^{88}\right)$.

A resposta dos intervencionistas não se fez esperar e, em comunicados tornados públicos a 10 e 11 de Outubro, repudiam a acusação do MND a quem, como «pequena minoria * $\mathrm{i}$

(") República, 8.X.53.

i $^{86}$ República, 10.X.53.

(") República, 11.X.53.

(88) Diário de Lisboa, 8.X.53. 
dissidente», não reconhecem «a qualidade de representante da Oposição» e reiteram o propósito de combater o regime «dentro do caminho legal» $\left({ }^{89}\right)$.

O abstencionismo não era porém exclusivo do MND. Era igualmente adoptado ou defendido por outras forças políticas, com intenções e colocações políticas diversas. A um abstencionismo apoiante da oposição, outro abstencionismo ultrancista se manifestou contrário à apresentação de candidaturas. Assim, o PRP pela voz do Dr. Carlos Olavo, membro do seu Directorio, manifesta a sua abstenção, já que «não quer dar, com a sua presença e a sua participação, foros de regularidade a umas eleições em que as listas dos candidatos se não apresentam em igualdade de condições». No entanto, não nega a sua simpatia às listas apresentadas pela oposição, «pelos princípios que proclamam e pelo denodo que manifestam os candidatos», e promete até a colaboração possível: «cada um de nós fará o que estiver ao seu alcance para que esse triunfo seja uma realidade» $\left({ }^{90}\right)$.

O Partido Socialista, através de um comunicado da Conferência Socialista de Lisboa, embora louve e saúde "a coragem cívica dos homens que figuram nas listas apresentadas em três círculos, pela Oposição», vinca a sua independência e isolamento, não se considerando representado nessa candidatura,

E que, «para que das próximas eleições adviesse algum benefício para o país, mesmo com a derrota total das oposições seria indispensável um mínimo de condições morais, que infelizmente não existem». Além disso a sua estratégia é outra, «precisa de anos e apóstolos para frutificar». O que não impede porém que dê «liberdade aos seus companheiros para votar e fiscalizarem as urnas até à contagem», sem porém participarem nas comissões ou assumirem delegação dos candidatos ( $\left.{ }^{91}\right)$. Também o Movimento Nacional Popular de Rolão Preto, embora sem concorrer, veio a público defender a convergência nacional em defesa da liberdade, recomendando o cumprimento do dever cívico no dia das eleições, o mesmo é dizer, convidando a votar na oposição $\left.{ }^{(92}\right)$.

Trata-se portanto de um abstencionismo colaborante, diverso do abstencionismo não pactuante, senão mesmo atacante, que vemos expresso pelo MND e ainda pela SPIO, e

\footnotetext{
O República, 10.X.53 e 11.X.53.

$\left.\mathrm{C}^{90}\right)$ Diário de Lisboa, 15.X.53.

(01) República, 21.X.53.

D República, 21.X.53.
} 
por um então desconhecido Partido Cristão Democrata (em organização), de duvidosa origem.

A SSPO, contra cujo comunicado o do Partido Socialista se insurgia, contestando-lhe representatividade, defendera, dias antes, o alheamento das eleições, «por não reconhecer a existência de um mínimo de liberdades e de garantias fundamentais de todos para todos» $\left({ }^{93}\right)$. O Partido Cristão Democrata, que nunca se identificou pessoalmente em público, e dizia que «só entrará em actividade pública, depois do reconhecimento e legalização pelas entidades oficiais» $\left({ }^{94}\right)$, vai mais longe: não se limitando a defender a abstenção, ataca a apresentaçã̃o de listas e a oposição, os processos dos seus «pseudo-dirigentes», que apenas tểm provocado o «desprestígio do movimento democrático», para defender uma oposição colaborante e mediadora: «uma oposição bem intencionada é a melhor colaboradora de um governo bem intencionado. Pode haver processos de execução diferentes mas o que deve interessar é que seja atingido o objectivo que se pretende: a melhoria de vida e dos direitos do povo português» $\left({ }^{95}\right)$.

No entanto a mais forte crítica do intervencionismo pertenceu ao MND que a 14 de Outubro num extenso comunicado - «O MND perante o actual momento político» - reiterou as razões do seu abstencionismo eleitoral. Responderam-lhe os intervencionistas de Lisboa - rotulando-os de «doidos da extrema esquerda» $\left({ }^{9 e}\right)$ - e os de Aveiro que, através de um dos candidatos, foram ao ponto de acusar o MND de não ser nem nacional nem Democrático, porque «visa simplesmente servir a causa do alargamento do imperialismo russo», denunciando-o como «nova alcunha dos chamados comunis$\operatorname{tas} \gg(97)$.

A divisão da oposição diminuiu a intensidade crítica da campanha contra o governo. Curiosamente, a maior luta foi dada ainda a nível cívico pela Comissão Promotora de Voto, que se bateu com o Governo por uma dignificação do processo eleitoral. $\left.{ }^{*}{ }^{*}\right)$

(") Diário da Manhã, 11.X.53.

(M) O Manifesto de tal Partido, por não ser assinado, despertou compreensíveis dúvidas sobre a genuinidade dos seus impulsionadores. $O$ P. Abel Varzim, que, como deputado, se notabilizaria durante a guerra pelas suas intervenções e preocupações sociais, desmentiria qualquer identificação e demarcar-se-ia dos promotores que considerou estarem «muito afastados das realidades» (Diário de Lisboa, 14.X.53).

(*) Diário de Lisboa, 10.X.53.

(") Diário de Lisboa, 15.X.53.

(") República, 18.X.53. 
Partindo da constatação, referida por António Sérgio, de que «com o recenseamento como foi feito e o medo que tolhe os cidadãos portugueses, nenhum candidato independente pode ter a esperança de ganhar eleições» ( $\left.{ }^{98}\right)$, a Comissão Promotora de Voto desencadeou uma série de protestos e exigências tendentes a rectificar o recenseamento e a possibilitar a fiscalização do acto eleitoral.

Em primeiro lugar, exigiu do Governo a possibilidade de consultar livre e integralmente os cadernos eleitorais para que também a oposição, e não só a União Nacional, pudesse averiguar da totalidade do recenseamento, o que era diferente da consulta restrita e individual de cada eleitor acerca da sua inscrição pessoal, que as autoridades queriam apenas autorizar ("), ou da obtenção, altamente dispendiosa, de certidões individuais, que também se possibilitava.

Como tal consulta fosse recusada, reivindica então o envio à Comissão Promotora de Voto de «cadernos idênticos às cópias parcelares, idênticas às que vão ser remetidas, em breves dias, aos presidentes das assembleias de voto», o que, atendendo à exiguidade do número de círculos em que a oposição concorria, se afigurava tarefa comportável.

Só assim, de facto, se poderia obstar a que várias irregularidades ocorressem ou fossem arbitrariamente cometidas, como a não inclusão ou o corte abusivo, tantas vezes detectado, de nomes de pessoas contrárias ao regime, ou a multiplicação de nomes de pessoas afectas à situação, ou ainda a não exclusão de pessoas falecidas ou incapacitadas pelas quais outras indevidamente se atreviam a votar (100). Só assim seriam dadas à oposição as mesmas possibilidades, conferidas à União Nacional, não só de controlar o recenseamento, como também de envio domiciliário das próprias listas de voto, evitando assim que quem quisesse votar na oposição tivesse que

(98) Entrevista ao República, 11.X.53.

(") Diz António Sérgio que até 1953 não havia cadernos, mas ficheiros, e que cada eleitor podia apenas consultar a sua ficha. O ficheiro, em 1948, ainda estava à vista, mas em 1953 nem isso. Era um «ficheiro oculto e a consulta exclusiva do funcionário» (idem).

$\left({ }^{10}\right)$ Um comunicado da Conferência Socialista de Lisboa, explicava como era facilmente conseguido esse "voto plural»: "Alguns bons milhares de cidadãos encontram-se legalmente recenseados duas, três, quatro, dez vezes mais e nada impede dentro da lei que eles aproveitem a oportunidade. Esses cidadãos que assim se destacam do vulgo são recenseados normalmente pela residência, mas pagam contribuições pelo comércio ou indústria que exercem, também com toda a normalidade, em freguesia diferente; generosamente a lei, impõe-lhes a pluralidade» (República, 21.X.53). 
procurar por seus meios a respectiva lista, e que ninguém, por outro lado, se sentiria obrigado a votar na lista da União Nacional que era exclusivamente distribuída domiciliariamente pela polícia. De facto, reconhecia-se, «foi imposta a todos a ida às urnas, já que os nomes são enviados aos agentes recenseados pelas proprias repartições, e já que por hảbil conselho dos chefes, ou por simples receio de denúncia, raros se terão negado ao acto, fiscalizável e físcalizado, da comparência. Daí que, portadores todos da mesma lista, não puderam fazer mais do que votar nos nomes indicados» (101).

Exigiu seguidamente a Comissão Promotora de Voto que todas as listas fossem impressas em idênticas condições, no mesmo local e em igual papel, contrariando casos passados em que isso não se verificara, e eliminando dificuldades invocadas na altura para obtenção do mesmo papel, o que efectivamente veio a conseguir.

Exigiu ainda igualdade de facilidades na utilização de microfones de emissoras e de edifícios públicos para sessões de propaganda, o que, ao contrário de garantias dadas pelo Ministro da Presidência nesse sentido, se aconteceu em Lisboa com a cedência do Liceu Camões, não se repetiu já em Lisboa com o Pavilhão dos Desportos e com o Estádio Nacional, e no Porto com a recusa do Liceu Carolina Michaëllis, ambos usados pela UN (102). O mesmo não aconteceu também com o Rádio Clube Português que retirou os microfones à oposição a partir do meio da campanha.

Exigiu por fim que os candidatos, ou delegados seus, pudessem exercer físcalização nas mesas de voto e nas assembleias de apuramento, para que pessoas recenseadas votassem mais do que uma vez ou não recenseadas o fizessem, como acontecia; para que não pudesse dar-se o caso de se saber antecipadamente o número de votos das listas antes do encerramento e contagem das urnas, como se verificou; para que a apresentação e identificação dos eleitores se fizesse pelos nomes e não pelos números constantes nos subscritos da União Nacional, como também se deu em mesas, cujos presidentes chegaram a perguntar por esses sobrescritos; para que não se adulterasse ou alterasse a contagem final dos votos.

Foi uma aguerrida luta travada com o Governo, com troca frequente de comunicados, que a Comissão Promotora de Voto viu muito longe de ter sido coroada de êxito. Os cadernos não foram facultados, as listas de oposição não foram

(101) República, 24.X.53.

(m) República, 25.X.53. 
domiciliariamente distribuídas, a fiscalização não só não foi completa, como muitos candidatos e delegados se viram impossibilitados de a fazer por recusa pura e simples da sua presença ou de credencial apresentada, ou porque algum escrutínio se fez à porta fechada.

A advertência de Egas Moniz no decurso da campanha de que «eleições sem físcalização da oposição, que segundo me disseram, o partido do governo não admite que exista, não merecem esse nome. São nomeações que podiam ser feitas no Ministério do Interior»! ( ${ }^{103}$ ) - não demoveu porém os intervencionistas de prosseguir. Tratava-se no dizer do Candidato portuense António Macedo em entrevista à República de «aproveitar as oportunidades para fazer a denúncia perante o país das irregularidades e das anomalias eleitorais que o governo seja obrigado a praticar para sobreviver» (104), mas também de ir forçando o governo a satisfazer as reivindicações apresentadas para eleições dignas e livres.

Apesar de não terem sido dadas todas as garantias suficientes, a oposição comunica publicamente que decide participar até ao fim e ir às urnas, porque entende «que as sucessivas desistências mais não têm feito do que enfraquecer as energias cívicas da população e que a elas cabem sérias responsabilidades neste marasmo político com que a situação se compraz, para viver, descuidada, na sua vida folgada e farta» $(105)$.

Como era de esperar os resultados conseguidos pela oposição foram modestos: 6.821 (8,7\%) em Aveiro, 21.104 (9,98\%) em Lisboa, 15.843 (11,8\%) no Porto, embora tenham obrigado os resultados da União Nacional, nesses círculos, a não irem além de 52,1\% em Aveiro, 50,1\% em Lisboa, e 52,9\% no Porto.

As eleições de 1957 vão porém inverter curiosamente as posições no seio da oposição ainda dividida, e onde a Comissão Promotora de Voto de António Sérgio continua a pugnar pela dignidade cívica e moral das eleiçôes (106). Os intervencionistas de ontem aparecem agora a defender a abstenção, já que, como justificam numa longa exposição enviada ao Presidente da República a 4 de Outubro, o governo se recusa a «promover a realização de eleições livres» e insiste em man-

(103) República, 28.X.53.

(104) República, 14.X.53.

Ò ${ }^{05}$ Diário de Lisboa, 4.XI.53.

(106) A Comissão Promotora do Voto dirigiu ao Ministro da Presidência duas exposições a 15 de Fevereiro e a 13 de Maio que ficaram sem resposta. 
ter as «insuficiências da lei eleitoral» $\left({ }^{107}\right)$. Cunha Leal, que não figura entre os assinantes, virá mais tarde a defender idêntica posição (108). E Rolão Preto, convidado a integrar como independente a lista de Lisboa, recusará alegando também não estarem satisfeitas as garantias de fiscalização do acto eleitoral por parte do Governo $\left({ }^{109}\right)$.

Por outro lado, um novo intervencionismo surge, mais disposto a disputar ao Governo o direito de existir como oposição, e a criticá-lo no terreno da governação, a que o PCP dá a sua adesão, invertendo a táctica até aí seguida. "O Partido- autocriticava-se $O$ Militante $\left({ }^{110}\right)$, — tomando os seus desejos por realidades, considerou o Movimento Nacional Democrático como a forma mais acabada de unidade e, por analogia, considerou o seu candidato à presidência da República, o Prof. Rui Luis Gomes, como o candidato que, na altura, melhor correspondia aos interesses de luta anti-salazarista». Por isso, o PCP retirado o seu apoio ao MND, que é dissolvido ainda em 1956, abandona e advoga a participação eleitoral, com base numa plataforma comum de reivindicações de condições mínimas: novo recenseamento, ampla liberdade de propaganda eleitoral e participação de democratas nas mesas de voto e assembleias de apuramento $\left({ }^{111}\right)$.

Surgem assim, como resultado desse novo intervencionismo listas de candidatos da oposição em Lisboa, Porto, Braga e Aveiro (112).

(107) Representação dos Democratas Abstencionistas a sua Ex. ${ }^{a}$ o Presidente da República. Eleições para a Assembleia Nacional em 3 de Novembro de 1957. Entregue em 4 de Outubro de 1957.

$\left.C^{08}\right)$ Diário de Lisboa, 23.X.57.

(109) Diário de Lisboa, 12.X.57.

(no) O Militante, n. 92 (Abril) 1957, citado por Diário da Manhãa, 9.X.57.

(m) Diário da Manhã, 28.X.57.

(112) Eram as seguintes as listas apresentadas:

LISBOA: Gen. Ferreira Martins, Lídia da Fonseca, M. J. Palma Carlos, Rui Cabeçadas, Câmara Reis, Rogério Paulo, Manuel Sertório, Arlindo Vicente, Nikias Skapinakis, José da Cruz Ferreira, Domingos Carvalho, Óscar dos Reis Figueiredo; AVEIRO: Manuel Neves, Virgílio Pereira da Silva, Júlio Calisto, Alfredo Magalhães, Costa Pereira, Manuel Pato; PORTO: Mem Verdial, Artur de Oliveira Valença, Artur Santos Silva, Manuel Coelho dos Santos, Augusto César de Barros, Amadeu Morais, Jaime Vilhena de Andrade, Artur Vieira de Andrade, Pedro Veiga, Rodrigo Teixeira Mendes Abreu; BRAGA: Luis Caseiro, José Justino Amorim, Eduardo Pereira Santos, Francisco Pinto Rodrigues, Guilherme Branco, Joaquim Borga. 
Apenas Câmara Reis, em Lisboa, e 2 candidatos por Aveiro da lista de 1953, figuravam de novo nas listas dos mesmos distritos. Em Lisboa é visível a participação de um importante núcleo da nova Direcção da Seara Nova.

Contrariamente ao que acontecera com a intervenção da oposição em 1953, que fora fundamentalmente civilista, isto é, mais voltada para a denúncia da antidemocraticidade e das irregularidades do processo eleitoral, e para a exigência da liberdade e pureza das eleições, (o que lhe valeria a crítica por parte da situação de não possuir um programa) (113), a intervenção, sem descurar a exigência das condições e a denúncia dos atropelos à liberdade eleitoral, vai pautar-se agora por uma crítica política ao governo e às suas políticas sectoriais, produzindo as candidaturas manifestos programáticos onde atacam o Governo na sua actuação política, económica, social.

Tal foi o caso dos candidatos de Braga, com um longo Manifesto $\left({ }^{114}\right)$, onde é visado particularmente o sub-desenvolmento do país que o regime governa há 3 décadas, e onde se apontam medidas tendentes à modernização da agricultura, ao desenvolvimento da indústria, ao alargamento das vias de comunicação, à melhoria dos salários, à revisão dos impostos, ao exercício das liberdades fundamentais. Desde logo porém se avisa aí que «estamos dispostos a disputar as eleições, e disputá-las-emos desde que o governo dê ao acto eleitoral as condições mínimas de dignidade, sem as quais esse concurso atraiçoaria os sérios propósitos que nos animam» $\left({ }^{115}\right)$.

Tal foi o caso igualmente dos candidatos do Porto que, proclamando-se independentes e não comunistas, contrários aos «totalitarismos das esquerdas e das direitas», denunciam o regime na «Proclamação ao Povo Português» (116) como responsável pelo sub-desenvolvimento do país, e apresentam no Manifesto uma série de pontos programáticos de actuar ção futura quer política (democratização das instituições, li-

(113) António Sérgio, virá no final da campanha justificar essa ausência, dizendo não ser objective da candidatura da oposição, tornarle governo, não precisando nem devendo ter a preocupação de um programa de governo. Em todo o caso, dá a conhecer um esboço de programa que alguns democratas a ele ligados haviam elaborado em oito Bases, (República, 5.XI.53).

(114> República, 6.X.57.

(115> República, 6.X.57.

(116) República, 7.X.57. 
berdades e garantias fundamentais) quer económica (revigoramento da iniciativa individual e empresas colectivas, valorização da agricultura e da indústria sem monopólios, protecção às pequenas e médias indústria e lavoura, adesão à CEE, mercado único português com o Ultramar) quer social (elevação do nível de vida, cooperativismo, seguro e previdência social, reformas fiscal e judiciária, protecção à infância, velhice e invalidez) $\left({ }^{117}\right)$.

Tal foi ainda o caso dos candidatos de Lisboa, em cujo primeiro comunicado se vê pela primeira vez, manifestar «repúdio do ideário totalitário do Governo e do capitalismo monopolista dominante, beneficiário e inspirador daquele». Considerando-se não «como candidatos da Oposição, mas sim como candidatos oposicionistas» explicam porque decidem intervir: «Desistimos de solicitar indefinidamente a concessão das condições necessárias ao livre exercício de voto como realidade prévia ao início do prélio.... é lutando, plenamente, até à exaustão, nas condições de momento, que paulatinamente poderemos alcançar no campo eleitoral aquilo de que carecemos: uma legislação honesta. Entendemos que nos tornaremos mais amplos, como cidadãos, a exercer o direito de voto nas condições peculiares ao normal exercício da Democracia, exercendo-o ainda nas piores condições do que renunciando voluntariamente a esse exercício por imperfeito». E respondendo aos abstencionistas: «não só nós, oposicionistas, nos robusteceremos cívicamente pelo exercício consequente dos direitos políticos que nos são reconhecidos como a nossa presença no pleito eleitoral funcionará precisamente como a única força moralizante do mesmo». Nesse sentido reivindicam do Governo uma cópia dos cadernos eleitorais e a possibilidade de fiscalização do escrutínio que põem como condições «imprescindíveis para a honestidade do acto eleitoral e seriedade dos resultados apurados» (118). E muito embora reconheçam não lhes incumbir a apresentação de um programa de Governo, insistem porém em traçar algumas normas programáticas de orientação: regulamentação na Assembleia Nacional de todos os direitos fundamentais, amnistia, abrogação das «medidas de segurança», elevação do nível de vida, distribuição equitativa de crédito, protecção às pequenas e médias actividades

(117) República, 15.X.57.

(U8) República, 16.X.57. 
económicas, redistribuição dos encargos fiscais, liberalização do associativismo de classe e cultural, novo estatuto civil da mulher, autonomia universitária e estudantil, plano de divulgação de cultura, abolição da censura e promulgação de uma lei de imprensa, estabilidade pecuniária e social dos artistas, ensino artístico) $\left({ }^{119}\right)$. Tais pontos mereciam um mais desenvolvido tratamento, num esboço do programa publicado pouco depois apresentado para estudo e debate das demais candidaturas $\left({ }^{12}\right)$ e que fora elaborado muito antes da campanha eleitoral por uma comissão de Candidaturas do Círculo Eleitoral de Lisboa, constituída em Julho, presidida por Azevedo Gomes, composta por Vieira de Almeida, Moreira de Campos, Carlos Pereira, Sá Cardoso, Mayer Garção, Acácio Gouveia, Nuno Rodrigues dos Santos, Fernando Homem de Figueiredo (ferroviário), José Hipólito dos Santos (estudante) mas que face à ausência de garantias a dar pelo governo optaria pela abstenção $\left({ }^{121}\right)$.

Tal foi, por último o caso dos deputados de Aveiro, que no documento de apresentação da candidatura fixaram também programáticamente «os objectivos imediatos de uma política de ressurgimento nacional»: actualização de salários, redução de intermediários, fomento de exportação, reforma fiscal, apoio técnico à agricultura, estímulo ao investimento agrícola, redução de despesas militares, reforço das verbas para a educação, justa aplicação dos fundos sociais, assistência materno-infantil, serviços médico-sociais, solução do problema da habitação, aumento da escolaridade obrigatória, igualdade sexual de direitos, amnistia política e substituição da censura por uma lei de imprensa (122).

Esta dualidade de comportamentos da oposição não escapou ao próprio governo, que dele procurou colher dividendos. Trigo de Negreiros, Ministro do Interior, falando no Porto a 9 de Outubro de 57, diferenciou publicamente os «liberais e democráticos» e os «de mentalidade diversa e por vezes oposta, que constituem, em muitos países, o partido do estrangeiro». "A abstenção de uns significará, por ventura, simples processo de combate - acrescentou - enquanto que a atitude de outros reflectirá o ódio à organização social e po-

(119) República, 16.X.57.

(120) República, 23.X.57.

(121) Diário de Lisboa, 20.X.57.

(122) Diário de Lisboa, 17.X.57. 
lítica e às instituições representativas, num nível e com alcance que transcendem o Regime. E esta mesma distinção ainda é verdadeira quando se trata de analisar no aspecto ideológico os agrupamentos oposicionistas que à abstenção preferem a acção»». Reconheceu porém o ministro que entre os intervencionistas «que serão possivelmente abstencionistas a prazo», há «confusões em que se corre o risco de se ser injusto. Mas dessa confusão não somos nós culpados. A responsabilidade pertence aqueles que não souberam preservar-se de contactos indesejáveis e alienar corajosamente solidariedades comprometedoras»! $(123)$.

Era um repto à Oposição, um convite à demarcação dos comunistas, se não queria ver-se tratada pelo Governo como eles eram tratados.

Era um apelo à colaboração, uma tentativa de descolar a «oposição construtiva» da «oposição sistemática e facciosa». «A oposição - disse o Ministro dias depois em Aveiro (124) entendida como crítica independente e fiscalizadora, capaz de censurar e louvar com imparcialidade, tem um papel útil e pode utilmente servir o país»y.

Os candidatos de Braga e do Porto, sensíveis à pressão das autoridades, enjeitam a acusação de "comunismo». "Somos homens liberais - diziam os primeiros $\left({ }^{125}\right)$ - abertos à convivência com todos, sem compromissos nem com o PC nem com a União Nacional. Homens independentes - cujos nomes, por isso mesmo, têm resistido intactos às calúnias de alguns dos nossos opositores, por mera exploração política já incapaz de iludir seja quem for, ora insinuam que somos comunistas (em discursos e comunicados) ora nos chamam burgueses-socialistas (no Diário da Manhã), enquanto, por outro lado, o Prof. Mário de Figueiredo, na sessão da União Nacional, em Braga, declarou, não acreditar que sejamos comunistas». Os segundos, por seu turno, voltam a insistir que são «alheios a partidos e contrários a totalitarismos da esquerda ou de direita, que não preconizam o regresso ao Partido nem concordam com a ordem política do Presente, antes proclamam a necessidade urgente de Portugal se integrar de facto e de direito na Comunidade Política dos Povos Livres do Ocidente, através de uma imediata e progressiva democratização das leis e das instituições» $\left({ }^{126}\right)$.

(123) Diário da Manhã, 9.X.57.

(124) Diário da Manhã, 17.X.57.

(125) Diário de Lisboa, 25.X.57.

(126) República, 23.X.57. 
Só os candidatos de Lisboa, em cujo programa figuravam pela primeira vez, uma crítica ao capitalismo monopolista, se furtou a tais declarações ou classificações. O Governo tomou-o por isso como alvo preferido, rejeitando a apresentação da candidatura. Os recursos interpostos pelos candidatos Palma Carlos e M. Sertório, não são atendidos pelo Supremo Tribunal Administrativo, e a oposição vê-se em Lisboa impossibilitada de concorrer.

Nos demais distritos, formulam-se então ao governo exigências mínimas como condição de participação, nomeadamente a obtenção de cópias dos cadernos de recenseamento, presença nas mesas eleitorais pelo menos de um secretário e de um escrutiñador indicados pela oposição, e um boletim único incluindo as duas listas (127).

A resposta do governo é a mesma de sempre: será facultada a consulta (obviamente individual) mas não qualquer cópia dos cadernos eleitorais (128). E como a passagem de certidões carece de indicação prévia dos nomes dos cidadãos que as requerem, que só a posse dos cadernos permitiria, os candidatos do Porto e de Aveiro, pedem ao Presidente da República, a 1 de Novembro, o adiamento das eleições por dificuldade de consulta dos cadernos em tão curto espaço de tempo, e no dia seguinte, véspera das eleições, perante o indeferimento das suas exigências, anunciam que se retiram.

Só os candidatos de Braga persistem na ideia de ir até ao fim, apesar das limitações da organização de propaganda, e do processo eleitoral. «Só indo às urnas - justificam-se contribuimos para despertar o eleitorado pela indiferença pela Coisa Pública em que o lançaram. É só indo às umas que contribuiremos para levar todos a exercerem o seu direito de intervir na vida da Nação e, portanto, a cooperarem desde já activamente na resolução dos problemas do povo português» $\left({ }^{129}\right)$.

A 3 de Novembro, a lista de Braga obtinha apenas 5.138 votos, isto é, $5,8 \%$ da opinião do eleitorado do distrito, contra $67,7 \%$ obtida pela União Nacional.

Esta campanha eleitoral fez porém surgir novos sectores na oposição. Importantes correntes de opinião pública

(12T) «9. ${ }^{\circ}$ Comunicado. Os candidatos independentes do Porto perante o acto eleitoral», República, 23.X.57.

(12S) Diário de Lisboa, 26.X.57.

(129) Diário de Lisboa, 25.X.57. 


\section{António Sérgio}

exprimiram pela primeira vez e de maneira nova o seu desacordo com o regime.

Tal foi o caso de um jovem grupo de monárquicos, entre os quais Francisco de Sousa Tavares, Barrilaro Ruas, Ribeiro Teles, Domingos Megre, Portugal da Silveira, João Camossa, que, aproveitando a formal «liberdade de voto» preconizada pela Causa Monárquica $\left({ }^{130}\right)$, veio a público demarcar-se do regime. Embora, não lhe negando até alguns elogios, dizem que é com um «sentimento de tristeza e de mágoa intelectual» que vêm o regime persistir no «dogma da intangibilidade governativa e da excelência administrativa» e no "princípio de autolegitimação do partido único». Denunciam a «inconstitucionalidade do sistema, e portanto, a continuação já anormal do Estado da Ditadura do País» e preconizam «o caminho para uma nova constitucionalidade», que passe pela melhoria das condições de vida e pela solução da crise cultural, mediante a restauração do prestígio da inteligência e hábitos da cultura, através da reforma da mentalidade.

Tal foi ainda o caso de alguns sectores católicos que, afastando-se do regime, obrigam o Novidades a precisar que «se os católicos .... não regateiam a sua admiração e o seu apreço pela figura extraordinária do Presidente do Conselho, não se lhes pode exigir, pelo facto de serem católicos, tenham de apoiar forçosamente todas as iniciativas políticas. Nas actuais circunstâncias não pretendem organizar nenhum partido político [como algum candidato situacionista propalara], nem desejam imiscuir-se nas lutas partidárias, mas ninguém tem o direito de lhes impor o sacrifício da sua maneira pessoal».... «Os católicos nunca regatearam a sua colaboração ao governo na obra construtiva, mas não podem ser, como tais serventuários de nenhuma situação política» $\left({ }^{131}\right)$.

Com as eleições de 1957 encerra-se um ciclo de vida da oposição ao regime iniciado em Outubro de 1949. O Governo não soubera tirar partido da guerra fria para cooptar parte da Oposição que chegara a mostrar-se disponível para uma cooperação, desde que o regime abrisse a representação parlamentar à presença de minorias não pertences à União Nacional. E o PC

(130) Dizemos «formal» pois a posição substancial da Causa era outra. Assim, o comunicado que concedia essa «liberdade de voto", dizia também que «sob a chefia excepcional do Presidente do Conselho, verdadeiro intérprete dos interesses nacionais, a nação não terá certamente de hesitar no caminho a seguir» (Diário de Lisboa, 16.X.57).

(131) Diário de Lisboa, 19.X.57. 
conseguira evitar a fractura da Oposição e manter válida a estratégia frentista por ele liderada. A par disso alargara-se com o descontentamento alastrante, o leque de sectores de opinião que integravam a oposição ao regime. Estavam de novo criadas as condições para uma reunificação e ampliação da oposição, que vai verificar-se na campanha para as eleições presidenciais de 1958.

\section{A reunificação da oposição: campanha do general Hum- berto Delgado}

Quando após as eleições para a Assembleia Nacional de 1957 a oposição começou a pensar no aproveitamento das eleições presidenciais do ano seguinte, estava longe da unidade que viria por fim a conseguir em Junho. E disso foi indício a apresentação de mais do que uma candidatura.

O Directorio Democrático Social pensou na reedição da candidatura do Aim. Quintão Meireles e no lançamento da candidatura de Jaime Cortesão. Para isso porém apresentou ao Presidente do Conselho uma série de reivindicações como condição de participação: liberdade para preparar a candidatura; cópia dos cadernos eleitorais; cédulas de eleitor; regulamento eleitoral que contemplasse a abolição da censura, a igualdade de acesso à rádio e televisão, e liberdade de reunião; reconhecimento dos delegados eleitorais para a fiscalização das operações de voto; segredo de voto garantido pela igual impressão de listas e integridade das urnas. E estabeleceu um prazo de dez dias para uma resposta satisfatória.

Como a resposta de Salazar não correspondesse positivamente às exigências postas, o Directorio, constatando aue «são impossíveis, com o actual regime, eleições livres» $\left({ }^{132}\right)$, resolve por isso, não apresentar candidatura própria, muito embora ressalvem simultaneamente que não se desinteressarão do acto eleitoral (133).

Tal ressalva justificava-se pelo facto de ter sido lançada por pressão de António Sérgio - que sempre preferira candidatos militares no activo - a candidatura independente de Humberto Delgado, que o Directorio bem depressa passaria a encarar com interesse e sem reservas $\left({ }^{134}\right)$, e logo a seguir a apoiar abertamente.

(132) Carta ao Presidente da República (República, 2.IV.58).

(133) Carta a Salazar de 8 de Abril.

(134) Entrevista de M. Azevedo Gomes à República, lldeMaio58. 
Os sectores mais à esquerda da Oposição, por seu lado, onde o PC ocupava lugar de destaque, preferiram um civil e «um candidato que se propusesse levar a campanha até ao escrutínio, aprofundando, assim a dinâmica do movimento de massas» (135). Nesse sentido conseguiram, primeiro, a aquiescência de Cunha Leal e, na impossibilidade deste, por motivo de saúde, apresentariam a candidatura de Arlindo Vicente, advogado lisboeta que fora membro da recusada lista de candidatos oposicionistas por Lisboa em 1957 (136).

As duas candidaturas apresentam-se ao eleitorado nos primeiros dias de Maio, com a publicação das respectivas proclamações.

Humberto Delgado um dos mais jovens generais portugueses, que ocupava no regime cargos importantes (137), apresenta-se como desiludido do 28 de Maio e do regime. Tendo dado a um e a outro a sua colaboração dispõe-se agora a repor a pureza do ideário do primeiro e da constitucionalidade do segundo, que julga traído e desfigurado. Candidato Independente - assim se proclama - «acima dos movimentos e particularidades partidárias», embora acusado pelos extremos

(135) M. Sertório, «A candidatura de Cunha Leal...» in O Jornal, 5.III.82.

(136) Cf. M. Sertório, idem e a polémica que se seguiu entre ele e o Contra-Almirante Ramos Rocha (genro de Cunha Leal) nos números subsequentes do mesmo jornal.

(137) Humberto Delgado fora efectivamente um homem do regime. Revolucionário do 28 de Maio, esteve com as forças da ditadura no 7 de Fevereiro contra os revoltosos. Comissário adjunto da Mocidade Portuguesa e Adjunto Militar do Comando Geral da Legião Portuguesa em 1936, viria a ser mais tarde procurador à Câmara Corporativa (em 1951 e 1952), Adido Militar em Washington, representante português no Comité Militar da NATO e, por último, Director-Geral da Aeronáutica Civil. Admirador de Salazar, a quem em 1937 dedicava um livro de palestras, (Aviação, Exército, Marinha, Legião, Lisboa, Casa Portuguesa, 1937) «em fervorosa, modestissima e imprópria homenagem», e de que enaltecera em 1939 as «qualidades de carácter, de fé no ressurgir da Pátria, de lealdade, de dedicação, de altruismo, de honestidade, de sacrifício, $\mathrm{de}^{\wedge}$ amor ao Exército», e ainda em 1958 reconhecia em entrevista ao Diário Ilustrado (10.V.58) que se lhe devia «no início uma obra de 'arrumacão'», mas que não era já «o economista que neste momento precisamos. Penso que chegou a sua hora... E certo: penso que chegou a sua hora. Todos os ditadores neste ponto são iguais - năo largam o Poder. Atrai-os a vã cobiça de mandar, como acontece com os actores e actrizes que nunca se acham envelhecidos. O espírito de larga maioria, hoje, é o inerente a uma Nação ansiosa de que o Presidente do Conselho deixe de sacrificar-se mais por ela - se é sacrifício trocar a vida de mal conhecido professor de Coimbra pela do dono de uma Nação a que fez perder a virilidade, ao abusar do remédio para a curar». Cf. Humberto Delgado. Antes... e... Depois..., Lx. 1961. 
de simpatizante ora do comunismo ora do fascismo, mas apoiado pelos «liberais», "democratas independentes e anti-totalitários», não enjeita, como «liberal» que se professa, qualquer apoio que lhe venha, desde que «ninguém, por deformação espiritual ou interesses desnacionalizados, nos queira privar, como povo ou indivíduos, dos elementos de dignidade humana essenciais na civilização cristã». Dirige-se nã̃o só à «Oposição declarada», mas também aos «sectores descontentes da situação», apresentando a sua candidatura como «ponto de partida para a solução pacífica, ordeira e evolutiva» da crise política. Promete opôr-se à «pressentida conjura para a restauração de uma monarquia absolutista» e ao "projecto urdido noutro sector de se suprimirem de futuro as eleições por sufrágio popular». Apresenta-se como defensor do regime republicano e da Constituição em vigor «enquanto a Nação não vir necessidade de livremente se decidir por outra», mas propõe desde já a «adopção progressiva e tão rápida quanto possível dos hábitos políticos correntes nos países democráticos». Defende o intervencionismo, contra o abstencionismo eleitoral dos que o propõem como candidato porque só assim se evitará o que está acontecendo: «o eleitorado vai perdendo o sentimento dos seus deveres cívicos e a parte de responsabilidade que the cabe na direcção dos negócios de Estado». O abstencionismo só serve para «justificar a suspensão do sufrágio popular e a substituição pelo voto orgânico corporativo»».

Candidato da conciliação, entre oposicionistas inconformados, e situacionistas descontentes, estabelece como programa mínimo: o cumprimento da Constituição, nomeadamente no tocante aos direitos fundamentais; a garantia de ordem pública por uma autoridade forte mas limitada pela moral e pelo direito; o pôr termo à corrupção administrativa, aos abusos e à confusão de poderes; combater a doença e a miséria, e elevar o nível de vida dos mais desprotegidos e de classe média; actualizar a integridade ultramarina; pacificar, reintegrando os que foram afastados e amnistiando os presos, por motivos políticos; promulgar nova lei eleitoral e realizar novas eleições gerais; manter e consolidar os compromissos internacionais, nomeadamente os assumidos no âmbito da NATO $(138)$.

Era nos seus propósitos, e no seu programa mínimo, uma candidatura moderada e conciliadora, de uma conciliação que Cunha Leal, em entrevista ao RCP, assim explicava:

(ia») Proclamação do Gen. Humberto Delgado. Candidato à Presidência da República. 
«aceitação da Constituição de 1933, o que não significa a sua perduração ilimitada, como transigência dos oposicionistas, à qual corresponderia, como transigência dos situacionistas o respeito pelos direitos humanos, consignados no corpo do seu artigo $8 .^{\circ}$, sem que leis regulamentares previstas em parágrafo, permitissem a proibição efectiva do seu exercício ou a sua restrição a limites intoleráveis e, a par disso, a promulgação de uma lei eleitoral decente, a reintegração de funcionários demitidos injustamente e uma ampla amnistia para os crimes político-sociais» $\left({ }^{139}\right)$.

Moderado e conciliador era também o leque dos seus principais apoiantes que integra figuras monárquicas como Vieira de Almeida, Rolão Preto, Almeida Braga, e republicanos como António Sérgio, Mário de Azevedo Gomes, Aquilino Ribeiro, Artur de Andrade, Olívio França, António Macedo, Vasco da Gama Fernandes, Teófilo Carvalho dos Santos.

Era ainda e sobretudo uma candidatura constitucional. Longe de pretender subverter ou alterar a Constituição, adoptava precisamente como programa cumpri-la, actuar sobretudo o seu artigo $8 .^{\circ}$. Mas a 10 de Maio, na Conferência de Imprensa dada no Café Chave de Ouro, anuncia destemida e peremptoriamente que, se for eleito, dentro das prerrogativas constitucionais, demitirá Salazar. Mais do que destruir o regime, o propósito que anuncia é despersonaliza-lo, ou por outra repôr a institucionalidade constitucional.

Se assim é formalmente, na prática porém, dada a identificação do regime com Salazar, a candidatura de Delgado volve-se em candidatura de compromisso, isto é, paradoxalmente, de oposição ao regime, sem repúdio do quadro constitucional.

Nessa mesma conferência de imprensa, anuncia que constituirá «um governo de características militares, capaz de assegurar a ordem e a tranquilidade», que suprima «as leis que contrariam o art. $^{\circ} 8 .^{\circ}$ da Constituição», e permita, «a constituição de partidos». "Mas até que se eleve o nível político do nosso povo, haverá necessidade de um governo forte e de autoridade, embora, como digo na minha proclamação, limitado pelo direito e pela moral» $\left({ }^{140}\right)$.

Contrário à excessiva duração das ditaduras - «uma ditadura tráz consigo a ideia de certa duração. Prolongada, cai na divinização, na tortura «gestápica», no científico aniquilamento mental de uma nação, no escândalo administra-

(139) General Humberto Delgado. «O Homem sem medo» p. 27. (140) Gen. Humberto Delgado. O Homem sem medo", p. 7. 
tivo, no regabofe dos protegidos do tipo Yes man - «sim senhor»- ( ${ }^{141)}$ e partidário da democracia como sistema político - «adentro das imperfeições dos homens, penso que a Democracia é o melhor compromisso para viver com dignidade e a felicidade $\left({ }^{142}\right)$ - deseja que o prazo para a realização de eleições gerais livres, que promete convocar se for eleito, seja o mais curto possível pois deseja «que as Forças Armadas, como nos países realmente civilizados, estejam fora da Política» (143).

E quando the põem o problema do comunismo, se legalizará o PC, se aceitará o seu apoio, limita-se a dizer que não resolve problemas cujos dados desconhece, e que, em princípio, como candidato independente, aceita que indivíduos livremente o apoiem e não como representantes de partidos (144).

Arlindo Vicente, por seu turno, era, decididamente um homem de oposição, sem qualquer ligação passada ao regime. Ao apresentar a sua candidatura em Manifesto ao País (145) coloca-se na tradição do MUD e das campanhas de 1949 e 1951, que diz ter-se consolidado em 1957 com o «movimento cívico intervencionista». Entre os seus apoiantes estão, de facto, muitos dos intervencionistas de 1957, sobretudo os mais próximos do PCP: Câmara Reis e o novo Grupo da Seara Nova, Mem Verdial, M. J. Palma Carlos, M. I. Aboim Inglês, Julião Quintinha, Papiniano Carlos, Ferreira da Costa, J. Seiça Neves, Pulido Valente, Blanchi Teixeira, etc.

Em relação à outra candidatura, observaria na primeira entrevista (146) com alguma intenção crítica, que «nós não temos qualquer responsabilidade no passado nem nos meandros da Ditadura». Um dos seus apoiantes iria mesmo mais longe numa sessão ao dizer publicamente que quem estava dividido em matéria de candidatura não era a oposição mas o regime $\left({ }^{147}\right)$.

No entanto o seu programa em nada contradizia o de Delgado. Propunha-se se fosse eleito acabar com a censura, libertar os presos político, formar um governo que garantisse a organização dos partidos - inclusivé o PCP — e a realização de eleições livres $\left({ }^{148}\right)$, garantir a permanência de Portugal

\footnotetext{
(141) Idem, p. 11.

(142) Idem, p. 13 .

(143) Idem, p. 14 .

(144) ídem, pp. 6, 7 e 23,

(145) República, 8.V.58.

(146) República, 9.V.58.

(147) República, 12.V.58

(148) República, 9.V.58.
} 
na NATO, colaborar com a Igreja. Ünica proposta diversa: propunha-se adoptar medidas visando a melhoria das condições de vida, antes mesmo da convocação das eleições $\left({ }^{149}\right)$.

A sua actuação pretendia-se igualmente na linha da candidatura de Delgado. Aberto a todos os apoios, reivindicava do governo, tal como Delgado, as garantias de um concurso eleitoral leal $\left(1^{\circ}\right)$.

Mas é a campanha de H. Delgado que desperta contudo grandes movimentações de massas por todo o país, de que foram impressionantes manifestações a recepção no Porto, a 15 de Maio, e a chegada a Lisboa, no dia seguinte.

Os apoios inclinavam-se crescentemente para a candidatura de Delgado. A Comissão executiva do PS, o Directorio do Partido Republicano, o Directório Democrático Social, a par de personalidades de renome (como Cunha Leal) e de grupos qualificados de oposicionistas «socialistas e democratas» $(151)$ entre os quais alguns antigos candidatos às eleições de 1957, vêem a público manifestar a sua adesão ao «general sem medo». Mário de Azevedo Gomes, vem defender a público também a complementaridade das candidaturas, em entrevista ao República, a 11 de Maio. A 26 desse mês, Manuel Sertorio, elemento preponderante do grupo Seara Nova, apoiante de Arlindo Vicente, defende publicamente a sua renúncia em favor de Delgado, e a constituição de um comando único eleitoral e de um organismo de salvação nacional $\left({ }^{152}\right)$.

A fusão das candidaturas era inevitável. A 30 de Julho é celebrado um acordo entre Humberto Delgado e Arlindo Vicente - conhecido por Pacto de Cacilhas - pelo qual o segundo desiste em favor do primeiro.

«A Oposição Independente e a Oposição Democrática, assim dizia a proclamação conjunta $\left({ }^{153}\right)$ - representadas pelos seus candidatos à Presidência da República, senhor General Humberto Delgado e senhor Dr. Arlindo Vicente em face

\section{V.58.}

(149) Conferência de Imprensa de Arlindo Vicente, República,

dando Delgado escrevia logo a 7 de Maio ao Ministro do Interior dando-lhe conta das dificuldades encontradas em não poucos sítios na cópia dos cadernos eleitorais. O mesmo fará Arlindo Vicente a 10 de Maio denunciando junto do Ministro, a dificuldade na obtenção de certidões de eleitor, e solicitando para fotografar os cadernos. E como tivesse pedido em vão a Américo Tomás, informação sobre o tipo de papel em que se propunha imprimir as suas listas, sugeriu a 14 de Maio ao Ministro do Interior que os três nomes dos candidatos fossem impressos numa só lista.

(151) República, 25 de Maio de 1958.

(152) República, 26.V.58.

(153) República, 31.V.58. 
da necessidade de estabelecer, nas urnas, uma unidade de acção contra o Governo verifícaram ser útil, e até decisivo, proceder imediatamente a tal unidade, e para isso, estabelecer a actuação comum nos seguines termos, que se comunicam à Nação.

As candidaturas prosseguirão, a partir desta data, a trabalhar em conjunto, e a final, representadas nas umas por um só candidato, o General Humberto Delgado, que se compromete, por sua honra e salvo caso de força maior, a tornar efectivo o exercício do voto até às urnas e a estabelecer, em caso de êxito, o seguinte:

a) Condições imediatas de aplicação do artigo $8 .^{\circ}$ da Constituição;

b) Exercício de uma lei eleitoral honesta;

c) Realização de eleições livres até um ano após a constituição do seu Governo;

d) Libertação dos presos políticos e sociais;

e) Medidas imediatas tendentes à democratização do País».

No dia seguinte, Arlindo Vicente convidava os seus apoiantes a votar em Delgado e a União Nacional aproveitava para logo atacar Delgado de ser o candidato dos comunistas. Delgado esclarece por isso de imediato em comunicado que, efectivamente, A. Vicente desistira em seu favor, mas que «jamais em qualquer momento, esperamos obter a adesão ou os votos dos comunistas, com os quais, por formação mental e política, nada temos a ver. Na defesa das liberdades, deles nos encontramos bem mais distanciados dos que os que julgam combater o comunismo. Tendo sido atacado pelos comunistas, como é do conhecimento público, o Candidato Independente não pode nem quer contar com os seus votos. De resto, todo o acordo estabelecido o foi com uma força da oposição autorizada, que estava realizando, na Imprensa e em Sessões Públicas, a sua campanha política. Não nos entendemos com qualquer partido, mas com um sector de descontentamento nacional, que tinha o seu candidato proposto» $\left({ }^{154}\right)$.

O Governo, surpreendido com a força da Oposição e com o impacto da candidatura de Delgado, procurara dificultar os movimentos do General, intimidando-o a ele e aos seus apoiantes. Várias medidas repressivas, limitativas ou intimidativas, são ou consentidas ou promovidas, desde ataques «anónimos» à residência de Delgado em Lisboa, à prisão de

(154) República, -1.VI.58. 
activistas da oposição, à proibição de publicações pela censura de comunicados e fotografias das recepções a Delgado, à proibição de reuniões em recintos abertos, às difículdades criadas na afixação de cartazes e à sua apreensão, ao impedimento de deslocações (como aconteceu com a proibição da ida a Braga no dia 1 de Junho, a pretexto de perturbar uma peregrinação ao Sameiro), às cargas da polícia sobre manifestantes (como a de 18 de Maio em Lisboa, por ocasião da sessão no liceu Camões), e, para cúmulo, como aconteceu em Lisboa e em várias zonas do país, ao afastamento compulsivo pela polícia do candidato das multidões e dos seus apoiantes, a quando das recepções e manifestações (155). Tudo isso justificava o Governo a pretexto de que, «em vez do esclarecimento do eleitorado, se procurava criar um clima de agitação social, de desordem e intranquilidade pública» (156) e de que havia "propósito evidente de criar uma atmosfera insurrectional $\left({ }^{157}\right)$. Por isso, se reuniram, numa clara manifestação intimidatória, a 19 de Maio e a 6 de Junho, os Altos Comandos Militares para «estudar medidas de segurança necessárias à manutenção da ordem e paz públicas» (10̃8) no primeiro caso, e para advertir solenemente, no segundo caso, na véspera de eleições, que «se compete à Nação ganhar a paz no dia 8 , compete-nos a nós mantê-la intransigentemente, inflexivelmente, sem reticências de qualquer natureza, no dia 9 , e sempre» $\left({ }^{159}\right)$.

A limitação de liberdade de propaganda eleitoral, acrescentou o Governo as já tradicionais dificuldades de controle das operações de recenseamento e de voto. Em vão solicitou

(155) No regresso a Lisboa, depois da apoteótica recepção no Porto, Delgado foi afastado pela polícia do percurso previsco, onde muita gente o aguardava, e obrigado a regressar a casa por outro trajecto. «Depois de vários incidentes - relata Delgado no discurso da sessão do Liceu Camões — e de Lisboa ter assistido a cargas de cavalaria e tiroteio, fiquei detido pela Pide e por forças policiais na minha residência. Ao querer dirigir-me para a sede dos serviços da minha candidatura, elementos que deviam ser da Pide e sem qualquer respeito pelas minhas prerrogativas de Oficial General, resistiram à minha tentativa para sair de casa».

Também no Norte a Comitiva que acompanhava Delgado era reduzida de vários a um ou outro carro apenas, porque a GNR, barrando as estradas não deixava passar os demais. (Cf. General H. Delgado, «O Homem sem medo», pp. 35-36). Manhã, 17.V.58.

(156) Nota oficiosa do Presidente do Conselho, in Diário da

(157) Nota do Ministro do Interior (in Diário da Manhã, 19.V.58) sobre os incidentes da véspera.

(158) Diário da Manhã, 20.V.58.

(159) Discurso de Santos Costa, Diário de Lisboa, 6 Junho 58. 
Humberto Delgado, ao Ministro do Interior «cópias completas dos cadernos eleitorais de recenseamento a utilizar na próxima eleição presidencial» $\left({ }^{160}\right)$ ou que essa cópia, autorizada após 10 de Maio, pudesse ser feita não só por escrito mas também por gravação ou fotografia, já que «a UN recebe esse trabalho feito e actualizado» e «as suas listas são distribuídas pelo correio e pela PSP - que não é um organismo eleitoral - e portanto sabem quem são os eleitores» $\left({ }^{161}\right)$. À oposição ficou uma vez mais vedado o acesso completo aos cadernos e, como tal, a igualdade de condições dadas à União Nacional, o que fez Delgado protestar em carta junto do Ministro do Interior: «Não compete ao Governo ajudar os candidatos da oposição a ganhar as eleições, mas também não lhe compete ajudar a União Nacional a ganhádas, e isso é o que a Nação não verifica» (162).

Não foram também dadas garantias de fiscalização, existindo hoje não já apenas dúvidas mas a certeza de que os resultados finais oficialmente publicados, foram viciados. E o próprio Marcelo Caetano, que, nas suas Memórias o admite, embora em termos que não alterariam o resultado do voto $\left({ }^{163}\right)$. De igual modo, António Sérgio, à frente de muitas outras assinaturas de apoiantes de H. Delgado, viria denunciar após o acto eleitoral, em exposição ao Presidente da República, que as eleições tinham sido uma «farsa indecorosa: na realização do acto eleitoral, um acervo de contradições, arbitrariedades, e violências; na distribuição geográfica e fundamentação social dos resultados da apuração, um absurdo tamanho, que só por si denuncia um estudado processo de viciação; e na sua totalidade, desde o começo até ao fỉm, uma espécie de assalto na via pública, que afronta o país e o desqualifica perante as nações civilizadas». E justificava: onde houve fiscalização, «a balança das listas inclinou-se a favor do candidato da Oposição», na organização dos cadernos eleitorais, «pela simples suspeita do seu liberalismo, milhares de cidadãos foram privados de sufrágio em todo o país»; quanto à distribuição das listas, uma «boa parte do País» fora privada delas, «antes de mais nada pela impossibilidade de as imprimir e as distribuir no pequeno espaço de tempo que o Governo concedeu às actividades eleitorais; em segundo lugar pelas dificuldades que as autoridades opuseram à sua dis-

(150) Carta ao Ministro do Interior de 21.VI.58 (Arquivo do

Min. Interior).

(161) Idem de 10.V.58.

(162) Carta ao Ministro do Interior de 10.V.58.

(163) Marcelo Caetano, Minhas Memórias..., p. 577. 


\section{António Sérgio}

tribuição, não excluindo o roubo de muitas milhares de listas»; na campanha eleitoral, mesmo nas vésperas das eleições, fizeram-se «muitas prisões para intimidar o eleitorado, proibiram-se sessões de propaganda», a censura amputou, truncou e suprimiu artigos, entrevistas, discursos e comunicados das comissões de oposição; a físcalização do apuramento secreto da votação fora impedida, anularam-se listas por motivos irrisórios, houve mesmo um Presidente de mesa que abria as listas, logo que entregues, e «rasgava as que continha o nome do candidato da Oposição»; "várias secções fecharam antes da hora marcada», e em muitas mesas foram eliminadas milhares de listas com o nome de Delgado (164).

Apesar disso a Oposição conseguiu os mais favoráveis resultados de sempre da sua história: $17,7 \%$, contra $52 \%$ do candidato do regime, triunfando mesmo em 429 freguesias do país $\left({ }^{165}\right)$.

Se Humberto Delgado saiu das eleições oficialmente derrotado os dividendos colhidos na campanha foram muitos. Nunca o regime fora tão profundamente abalado nos seus alicerces. Alguns dos seus apoios tradicionais começaram a dar indícios de importantes defeções, nomeadamente entre monárquicos e católicos.

Apesar de a Causa Monárquica ter mantido a tradicional posição de neutralidade formal favorável a Salazar, ou seja, enaltecendo Salazar deixa porém aos seus filiados a liberdade de voto tendo porém em vista a «manutenção do prestígio de Portugal no mundo e a salvaguarda do bem comum» (166), o certo é que importantes sectores monárquicos surgiram a apoiar H. Delgado. E entre os católicos, não foi só um grupo reduzido, mas significativo, de personalidades progressistas que lamentam publicamente a acção do jornal Novidades durante a campanha, que acusou de não ser nem esclarecedor nem imparcial. É também e sobretudo a famosa carta do Bispo do Porto a Salazar de 13.VII.58, explicando-lhe porque, ausente no estrangeiro, se recusava a vir a Portugal votar e exprimir o seu apoio ao regime.

No final da campanha, o próprio Salazar reconhecerá que a frente nacional de apoio ao regime fora rompida por «uns tantos, poucos, monárquicos» e por «alguns católicos». «Este último facto considero-o de maior gravidade, não pela perda de elementos que individualmente se afastem da frente

(164) In Eleições no regime fascista, Presidência do Conselho de Ministros. Comissão do Livro Negro sobre o Fascismo, 1979 (2. $\left.{ }^{\mathrm{a}} \mathrm{ed}\right)$. (165) Relatório do Ministério do Interior.

(16e) Diário da Manhã, 25.V.58. 
nacional, mas pela perturbação lançada em muitas consciências, até agora tranquilas, acerca da legitimidade das suas posições religiosas e políticas» $\left({ }^{167}\right)$.

No entanto, esta grande unidade eleitoral da oposição em tomo do General Humberto Delgado seria precária e cedo se dissolverá. O Movimento Nacional Independente por ele liderado, criado a 18.VI.58 após as eleições, para dar continuidade à campanha, será fortemente afectado pelas condições de clandestinidade e de exílio que o regime lhe imporá. Com efeito, Delgado é afastado do activo militar a 7 de Janeiro, acusado de violar o estatuto de oficial do Exército por exercer acção de carácter político, reincidir em «afirmações injuriosas para os membros do Governo e o Presidente da República», por se dedicar «à chefia e organização do movimento clandestino» e por prestar declarações políticas em entrevistas à imprensa estrangeira reputadas de «carácter abertamente subversivo» (168). E a 12 desse mês, para evitar a prisão iminente, pede asilo à Embaixada do Brasil em Lisboa, partindo definitivamente para o exílio a 20 de Abril de 1959. Em finais de Junho de 1960 acabará por ser demitido das Forças Armadas ( ${ }^{169}$ ).

Com as condições que lhe são criadas, o leque dos apoios ao general vai-se progressivamente reduzindo, vindo no futuro a assumir maior importância o dos sectores mais radicais de esquerda, entre os quais o do PCP. Quando porém a PIDE o abate a tiro, em 1965, junto à fronteira luso-espanhola, Delgado era um homem praticamente só e abandonado.

\section{Retorno ao abstencionismo generalizado (1961-1965)}

A Oposição reunida em tomo de Humberto Delgado, desgarrara-se internamente com o exílio a que o General fora forçado, após as eleições. Além disso, o desenvolvimento de uma crescente oposição internacional à polítiça colonial, que o caso de Goa e o desencadear das guerras de África vêm acelerar, nos começos da década de 60, repercutem-se no interior do país e da Oposição, criando novos problemas à unidade de oposição ao regime e proporcionando ao regime um alargamento do consenso com base na questão colonial. Ou

(16T) Salazar, Discursos, vol. V, Coimbra Editora, p. 516.

(168) Diário da Manhã, 7 Janeiro 59.

(169) «Nota Oficiosa do Gabinete do See. Estado da Aeronáutica», Diário da Manhã, 28.VI.60. 
melhor: a oposição, ao confrontar-se com a agudização das contradições do colonialismo português e com as suas repercussões ao nível interno e externo, vai ser obrigada a reexprimir-se e a reordenar-se.

É precisamente pela «gravidade do momento histórico» que se vive nos começos da década, ditada pelos «dados actuais do problema ultramarino», que um importante sector interno da «oposição democrática, republicana, liberal e socialista», sob a égide de Jaime Cortesão, e reunindo nomes tanto dos sectores abstencionista como intervencionista da década anterior, se dispõe a elaborar nos começos de 1961 um Programa para a Democratização da República. Dado que o regime persiste em adoptar respostas à grave crise nacional que apenas encaminham o país para o isolamento internacional, a Oposição decide vir a público tomar posição. Abandona o que considera «oposição clássica», que «por amor às suas convicções, por posição ideológica, por proceso de raciocínio, sempre recusou ao regime qualquer espécie de colaboração «ou qualquer medida de apoio», e passa a adoptar uma nova atitude já que se formou «uma vaga crescente de descontentamento e de decepções. que hoje se identifica verdadeiramente com o próprio corpo do país». Porque «agora, a Oposição tem de preparar-se para ser Governe, robustecer em si a consciência das suas responsabilidades, as que detêm neste momento de viragem histórica e as que a esperam num futuro que se aproxima e se desenha à vista de todos», por isso mesmo «tem que entender que há uma nova medida e um novo estilo de necessidades dos povos, uma posição diferente de integrar o sentido e a urgência dos problemas nacionais, ser capaz de seriar cada particularismo no esquema inflexível do interesse de todos»».

Por isso se abalança a Oposição a apresentar um programa que mais do que de governo é programa de transformação do regime, em linhas gerais, mas também em traços particulares, de políticas sectoriais. Assim, a par de medidas imediatas para a «restauração da ordem democrática» (como o restabelecimento das liberdades públicas, a promulgação de nova lei eleitoral, a liberdade de formação de partidos políticos, a libertação de presos políticos, a readmissão dos funcionários despedidos por razóes políticas, a liberdade sindical, a extinção das organizações fascistas e paramilitares, a extinção da PIDE e dos Tribunais Plenários, inquérito aos abusos do poder e às fortunas fraudulentas a entregar aos tribunais) e para a «liquidação da organização corporativa» (extinção das corporações, integração na administração pública dos organismos de coordenação económica, transforma- 
ção de grémios em associações de classe, e das casas do povo e dos pescadores em cooperativas), surgem arrumadas por capítulos, medidas para a reforma administrativa, para o estabelecimento da liberdade religiosa, para assegurar os direitos fundamentais aos povos do ultramar (na democratização, no desenvolvimento e na descentralização) para a reforma da justiça e do ensino, para o desenvolvimento da economia e a melhoria das condições de vida, para a reforma fiscal, agrária e industrial, e ainda para uma melhoria das condições de trabalho e previdência, de saúde, de habitação e de defesa nacional. Por último, um capítulo dedicado à política externa, a desenvolver de acordo com a carta da ONU, as alianças históricas, a abertura a todos os países da ONU e a normalização das relações com os novos estados independentes de África e da Ásia. O Programa, que fora elaborado antes do eclodir da revolta em Angola, mas que fora publicado já depois dela, com um apelo a «reencontrar na paz - nunca na guerra - o caminho do diálogo entre as populações e o asseguramento de todos os direitos» dos territórios ultramarinos.

O Programa para a Democratização da República - assinado a 31 de Janeiro, entregue na Presidência da República por Mário de Azevedo Gomes, Acácio Gouveia e Eduardo de Figueiredo, a 6 de Fevereiro, e tornado público em Conferência de Imprensa a 11 de Maio de 1961 - vai ser o estandarte da Oposição nas eleições que no Outono dessa ano têm lugar, sob o signo agitado do começo da guerra de Angola, e ainda sob o efeito do abortado golpe de Estado do Gen. Botelho Moniz, em 14 de Abril de 1961.

A Oposição, reunida em torno desse Programa, cuja publicação o Governo proibira, chegando mesmo a prender alguns dos signatários (entre os quais Mário Soares, Piteira Santos, Acácio Gouveia e Gustavo Soromenho), sob o pretexto de o haverem distribuído à imprensa estrangeira, entra na campanha eleitoral de 1961, para dela apenas colher as possibilidades de propaganda e de denúncia do regime, vindo porém a desistir à boca das urnas, já que o Governo, uma vez mais, se recusa a satisfazer as condições de participação postas pela Oposição.

A 20 de Setembro foi entregue por Adão e Silva uma exposição da Oposição a Salazar em que exigem, como condições para a participação no acto eleitoral, a libertação dos oposicionistas presos sem culpa formada, entre os quais alguns signatários do PDR, como Mário Soares e Piteira Santos; a publicação do mesmo PDR; a igualdade de circunstâncias para a Oposição e para a União Nacional no uso dos meios de comunicação social para propaganda; a neutralidade do Gover- 
no na campanha; a criação de um órgão de fiscalização e arbitragem do acto eleitoral; e a marcação da data das eleições. A resposta de Salazar é ou negativa ou evasiva (170), e as exigências da oposição não são por isso satisfeitas. Em resposta ao novo requerimento da oposição republicana de Lisboa, de 19 de Outubro, o Governo, através do Ministro de Estado Correia de Oliveira, fundamenta mais detalhadamente as razões da recusa: o FDR não pode ser aceite como programa de campanha eleitoral da oposição «por se propor ou consentir a subversão de princípios que são a própria essência de Nação; a propaganda apenas pode ser feita pelos candidatos nos círculos onde se candidataram; os oposicionistas presos não o estão por serem signatários do PDR; não é praticável a consulta aos cadernos eleitorais, nem outra fiscalização diversa da que é confiada aos escolhidos do governo.

Mesmo assim, a Oposição decide apresentar listas em oito distritos do Continente - Aveiro, Braga, Castelo Branco, Coimbra, Leiria, Lisboa, Porto e Santarém - no Funchal, e em Moçambique (171 ). Em Braga surgem mesmo duas listas da Oposição, reflectindo as duas tendências que, na década anterior, se haviam evidenciado no seio da Oposição. E em Lisboa, a par da candidatura da Oposição republicana e de-

(170) Despacho do Chefe do Governo, Diário da Manhã, 13.X.61.

( $\left.{ }^{\mathrm{m}}\right)$ Eram os seguintes, os membros das referidas comissões:

AVEIRO: Adolfo de Almeida Ribeiro, António Teixeira da Silva, João Sarabando, José de Oliveira e Silva. Manuel das Neves, Virgílio Pereira da Silva; BRAGA: Lista B: Alfredo Vieira Gomes, António de Oliveira Braga, Guilherme Branco, Joaquim Borges, Miranda de Andrade; Lista C: António Pinheiro Braga, Elisio de Azevedo, Francisco Alberto Pinto Rodrigues, Luis Manuel Guedes Pinheiro, Mem Tinoco Verdial, Victor de Sá; CASTELO BRANCO: António Alçada Baptista, Armindo Gonçalves Ramos, João Alexandre Sá Lima e Vasco Luis Rodrigues da Conceição e Silva; COIMBRA: Carlos Almeida, Fernando Vale, Fernando Lopes, Manuel Lousã Henriques, M. Montezuma de Carvalho, Mário Silva; LEIRIA: Alberto Ferreira, Eduardo Carvalho da Silva, J. Constantino Correia Rosa, José Ferreira Júnior, Vasco da Gama Fernandes; LISBOA: Agostinho Sá Vieira, Augusto Casimiro, Carlos Prazeres Ferreira, César dos Reis Ferreira, Francisco Lino Neto, Gilberto Ramos, João Varela Gomes, Luis Dias Amado, Nikias Skapinakis, Nuno Pinto da Costa, Nuno Ribeiro dos Santos, Olindo de Figueiredo; PORTO: Alberto Andrade, Antonio Macedo, Armando Bacelar, Armando Costa, Arnaldo Veiga Pires, Artur Santos Silva, Helder Ribeiro, J. Araújo Correia, Mário Cal Brandão, Olívio França; SANTARÉM: Alfredo Coelho de Guimarães, António da Silva Teles, José F. Rodrigues Pinhão, José dos Santos Lopes, Orlando R. Duarte Pereira. 
mocrática, surge, pela primeira vez, uma lista monárquica de oposição.

A Oposição republicana dos oito distritos do continente procura pela primeira vez, em eleições legislativas, uma coordenação de esforços a nível nacional. Nesse sentido promove uma reunião das respectivas comissões em Leiria a 14 de Outubro. Dele sai o primeiro Manifesto conjunto dos «oposicionistas republicanos» que é publicado na imprensa a 25 desse mês, onde se explicam as razões e as condições de participação. Embora a «falta de garantias e as fraudes registadas em actos anteriores» pudessem aconselhar a não intervir, para não «legitimar com a presença da oposição um processo político reprovável e permitir que se extraiam dos resultados, para efeitos de propaganda, ilações destituídas, na realidade, de fundamento», - como o pretendiam alguma franjas da oposição, a «hora crítica que o país atravessa», com o agravamento do problema ultramarino, e o crescente isolamento internacional que a política do governo provoca, levam a oposição a marcar posição, para que internacionalmente se saiba que não há «um geral acordo quanto à política do Governo, mormente nos aspectos cruciais do ultramar». Mais, entende a Oposição vir apresentar ao país uma "solução constitucional» para o problema da «substituição do actual governo, julgado como indispensável à restauração do nosso prestígio internacional».

Mais do que pedir votos ou "chamar sobre os seus nomes o favor do público», o propósito da oposição é o de condenar publicamente a política ultramarina do Governo, «a falta de visão, e a política errada que vem seguindo na administração ultramarina», para que "se prepare para o problema solução democrática que leve em conta a vontade, livremente expressa, dos povos interessados e os conduza a uma autonomia que se mostre indubitavelmente proveitosa ao seu progresso e valorização social».

Repete no entanto no Manifesto as condições para participar no acto eleitoral: libertação dos presos políticos, nomeadamente dos signatários do Programa para a Democratização da República; a publicação do mesmo Programa; e medidas que acautelem a «seriedade do acto eleitoral» $\left({ }^{172}\right)$.

A este Manifesto conjunto outros manifestos se vieram juntar dos candidatos aos respectivos distritos, justificando

Lisboa, 25.X.61.

«Manifesto dos Oposicionistas Republicanos», Diário de 
a intervenção pela gravidade do momento político e estabelecendo as condições para levar ao fim a campanha eleitoral.

O Governo por seu turno, em face da pressão e das exigências da Oposição, preferiu atacá-la no seu terreno. Invocando igualmente o problema ultramarino, não para defender a necessidade de debate, mas para justificar a recusa de qualquer abertura de brecha na rectaguarda, o Governo e a União Nacional acusaram por isso a Oposição de fazer o jogo do inimigo. «Não são possíveis as discussões quando o inimigo exterior se encontra à vista e a cidadela se sabe ameaçada. Os desentendimentos não contam quando as energias nacionais estão mobilizadas para intervir onde se mostre necessário à defesa do nosso Ultramar» - assim argumentava a União Nacional no seu primeiro comunicado de campanha do acto eleitoral (173).

Acusando a Oposição de dividir, em primeiro lugar, ao pretender discutir, e de fomentar o separatismo com a simples defesa de auto-determinação, a União Nacional, que pretendia lançar sobre ela o labeu de anti-patriotismo, aproxima também, noutros dos seus comunicados (174) o Manifesto da Oposição das posições do PCP de «liberdade e independência dos povos das colónias portuguesas»».

$\mathrm{E}$ no tocante às reclamações respeitantes ao processo eleitoral, União Nacional e Governo invertem a acusação, e responsabilizam o eleitorado pelas reconhecidas deficiências do recenseamento. "As imperfeições que porventura no recenseamento eleitoral se verifiquem, atingindo cidadãos de qualquer dos sectores da opinião política, deve-se apenas, à inércia dos próprios interessados» - dizia outro comunicado da União Nacional (175) confirmando o que, pouco depois, o governo repetiria pela voz do Ministro de Estado: «se, porventura não estão inscritos nos respectivos cadernos eleitorais todos aqueles que desejariam votar a favor das listas da Oposição, a responsabilidade desse facto não pode ser imputada ao governo mas tão só aos que dele, agora e só agora, reclamam» (176).

Perante a persistência do Governo em não querer aceitar nem permitir a discussão do problema ultramarino e em não querer satisfazer as exigências relativas ao processo eleitoral, a Oposição decide, numa reunião nacional em Coim-

\footnotetext{
(173) Diário da Manhã,25.X.61.

(174) Diário da Manhã,31.X.61.

C75) Diário da Manhã,26.X.61.

(1T6) Diário da Manhã,21.X.61.
} 
bra, a 28 de Outubro, enviar um apelo ao Presidente da República.

Já que o Governo de Salazar não tem apoio da Nação, não soube evitar a tempo, com uma «sábia e previdente política ultramarina» a crise de Angola, que «criou no estrangeiro uma animadversão contra Portugal, que arrastou na sua onda avassaladora os nossos amigos e a nossa tradicional aliada», e persiste em fazer as eleições sem imparcialidade e isenção, a Oposição pede, «em último recurso» ao Presidente da República que substitua o governo por outro «que inicie uma nova era para Portugal, respeite a constituição e com ela os direitos e garantias dos cidadãos e presida, em perfeita posição de neutralidade, às eleições». Isto é, que se crie «um clima político, de compreensão e convivência cívica que.... possa no plano interno estruturar um Estado moderno e portanto, democrático, no plano do Ultramar criar condições que permitam, em base democrática, evitar a desintegração do Portugal Uitramarino, e no plano estrangeiro, com tais medidas, readquirir o prestígio perdido» $\left({ }^{177}\right)$.

Perante o mutismo do Presidente da República, a Oposição decide optar pela desistência colectiva, comunicada ao país em Manifesto a 7 de Novembro, por uma vez mais constatar «ser impossível em Portugal, sob a actual situação política, sem governo, sem mandatários e sequazes, a realização de eleições livre e decentes»».

As eleições de 1961 vieram evidenciar o que já em 1958 se esboçara: a passagem declarada à Oposição ao regime de alguns mais importantes sectores monárquicos e católicos, e o aparecimento, pela primeira vez, de uma oposição organizada na Madeira e em Moçambique.

Claro indício do primeiro caso foi a apresentação de uma lista de monárquicos independentes $\left({ }^{178}\right)$ cuja aceitação o governo recusou. Preocupados com a questão do Ultramar, os monárquicos independentes, decidiram intervir por considerarem «injusto e perigoso, que a união dos portugueses, que se caldeia sob o signo da tragédia africana, viesse a tomar o aspecto de um plebiscito em favor do regime, visto que o que está em causa é a própria liberdade e a existência da Pátria; e assim a nossa presença de homens livres, que rejeitam as tiranias ideológicas, venham elas da esquerda ou da direita,

(1TT) Diário de Lisboa, 6.XI.61.

(178) A luta era integrada por Fernando Amado, Mário Pessoa, Ramos Ferreira, Sousa Tavares, G. Ribeiro Teles, Vasconcelos e Sousa, João Camossa, Almeida Monteiro, Vaz Pinto, Moutinho Rubio, Costa Félix, Maria Ofélia Portugal da Silveira. 
deve servir neste acto de tamanha magnitude, ao esclarecimento das verdades essenciais» (179). Por outras palavras, entendendo que a «hora gravíssima para os nossos destinos» é uma hora de unidade, e que essa unidade «exige a maior consciencialização dos perigos e dificuldades a vencer» e o «debate em nível político dos problemas nacionais», concluem que ela «não pode resultar senão de uma participação aberta dos portugueses de todos os sectores na vida nacional» e não de uma sujeição passiva aos ditames do Governo $\left({ }^{180}\right)$.

A própria Causa Monárquica entendeu vir a público lamentar que a elaboração das listas das «candidaturas propostas em apoio à acção nacional do Governo» não fosse suficientemente representativa e independente, por não dar «inteira satisfação aos legítimos anseios da Nação», nem se situar «ao nível das responsabilidades correspondentes aos sacrifícios que talvez sejam pedidos a todos os portugueses, no decurso dos quatro anos da próxima legislatura» (181).

No que toca aos católicos, tornou-se notório o aparecimento de alguns nomes conhecidos como católicos, conotados com o pensamento democrata-cristão, entre as candidaturas da oposição, nomeadamente os do Eng. ${ }^{\circ}$ Francisco Lino Neto $\left({ }^{182}\right)$, em Lisboa, e do Dr. António Alçada Baptista $\left({ }^{183}\right)$, em Castelo Branco. Ambos pertenciam ao grupo de subscritores de vários documentos que, a partir de 1958, trouxe ao conhecimento público a existência de uma corrente católica progressista ${ }^{184}$. E em Aveiro, um grupo de católicos enviou uma carta aberta às duas listas concorrentes da União Nacional e da Oposição $\left({ }^{185}\right)$. O Episcopado entendeu por isso vir a público falar do momento político, para refutar a acuação, contida no Programa para a Democratização da República, de que a Igreja estaria em Portugal «comprometida relativamente aos métodos de governação totalitária», para condenar igualmente a proposta aí contida de laicização do ensino, para avisar que

(179) Diário de Lisboa,16.X.61.

(180) Diário de Lisboa,28.X.61.

(181) Diário de Lisboa,19.X.61.

(182) Filho do antigo presidente do Centro Católico, António

(iss) Director da Editora Moraes (que teve importante papel na divulgação no pais da bibliografia conciliar e católico-progressista, de matriz personalista) e da Revista O Tempo $e$ o Modo. $O$ seu nome foi várias vezes associado à tentativa de lançamento em Portugal, nesses anos, de uma força política de orientação democrata-cristã.

(1M) Cf. José Felicidade Alves (ed.) Os católicos e a política, De Humberto Delgado a Marcelo Caetano, Lisboa, s.d. $\mathrm{O}^{85}$ ) Diário da Manhã, 3.XI.61. 
«a nenhum católico é lícito aliar-se na empresa política, com aqueles que negam Cristo e querem destruir, ou pelo menos encadear e emudecer a Igreja» e para recordar que o Santo Ofício proibia os católicos de «votar não só nos comunistas mas ainda naqueles que se aliassem com eles». Voz discordante porém, em Moçambique, o jornal da Diocese da Beira pronunciava-se sobre o direito e dever de votar em termos onde implicitamente se criticavam acções do governo em matéria eleitoral. «O cidadão eleitor tem o direito de não ser excluído da votação e de pedir responsabilidades se, por culpa de outrém, fica impossibilitado de usar desse direito. Este último aspecto põe o problema da capacidade de votar. A capacidade para votar, ou, se se quiser, a maturidade política, depende não tanto das categorias particulares dos indivíduos como da educação política comum a todas as categorias de país determinado» $\left({ }^{186}\right)$.

Em Moçambique apareceu precisamente como dissemos, tal como na Madeira, pela primeira vez na história do regime, uma lista de candidatos da Oposição que viria a ser administrativamente silenciada sob a acusação de defenderem a auto-determinação do território.

Os anos de 1961 a 1965 viram intensificar-se a guerra colonial nas três frentes de Angola, Guiné e Moçambique. Os problemas do país agravaram-se com o alastrar da guerra, sem que o regime desse mostras de querer alterar a sua orientação e a sua indisponibilidade para aceitar qualquer colaboração da Oposição na sua resolução. Pelo contrário, o ataque às actividades oposicionistas não cessara, e conhecera no começos desse ano de 1965 um nível particular de gravidade, com o assassinato do Gen. Humberto Delgado.

Quando, por isso, no Outono de 1965 a Oposição se vê confrontada de novo com a perspectiva de eleições, o cepticismo político aconselhava de novo o abstencionismo. No entanto, porque "há verdades sufocadas no peito de cada patriota que precisam de ser ditas» - argumentou-se-, porque «há denúncias de graves atropelos que têm de ser publicamente formuladas», porque «há escandalosas negociatas, escondidas por detrás de sonoras tiradas de pseudopatriotas, que têm de ser conhecidas pela consciência nacional» $\left({ }^{187}\right)$, um sector da Oposição, onde estavam representados democratas, socialistas e comunistas, afirmou-se «partidário da interven-

(186) Diário de Lisboa, 17.X.61.

\footnotetext{
15.X.65.

(187) "Manifesto à Nação da Oposição», Diário de Lisboa,
} 
ção». Apresenta candidaturas em 5 distritos - Lisboa, Porto, Leiria, Viseu e Braga - , e os candidatos dos quatro primeiros distritos apresentam ao país, em conferência de imprensa, um Manifesto onde, a par de uma solução pacífica e não militar para o problema ultramarino, «com base no princípio da auto-determinação, processada por métodos democráticos», indicam 5 pontos fundamentais sobre os quais pretendem que se faça um esclarecimento: o assassinato do General Humberto Delgado, o problema dos detidos pela PIDE, o encerramento da Sociedade Portuguesa de Escritores, o ocultamento à opinião pública do Relatório da ONU contra a política colonial, e o tratamento dado à juventude académica. Além disso, numa representação à Presidência da República, estabelecem-se claramente condições de participação não só no acto eleitoral mas na própria campanha, logo reiteradas publicamente no Manifesto ao País: conhecimento prévio dos cadernos eleitorais, liberdade e tempo de propaganda e de organização, acesso aos meios de comunicação social sem entraves da censura. acesso a recintos públicos para realização de sessões, físcalização das assembleias de voto. Mas põe-se desde logo ao Presidente da República o dilema: «ou o governo nos assegura sem ambiguidades nem sofismas um mínimo de decência», ou na hipótese contrária, os signatários renunciarão $a b$ initio a participar numa campanha condicionada segundo os interesses partidários do governo - o que só poderia conduzir à repetição, como nas campanhas anteriores, de nova farsa eleitoral» $\left({ }^{188}\right)$.

Foi o que efectivamente, poucos dias depois, aconteceu. Perante a ausência das garantias solicitadas, e face à reedição de medidas discriminatórias para com a Oposição, com a declaração de ineligibilidade de candidatos (que se verificou em Braga), a Oposição de Lisboa, Porto, Leiria e Viseu anunciou publicamente a sua desistência em carta ao Presidente da República, não sem previamente repudiar a acusação de traição à Pátria que os defensores do regime lhes lançaram pela defesa da autodeterminação ultramarina (189).

A lista oposicionista de Braga, a que o Supremo Tribunal Administrativo reconhecera, contra decisão anterior do

(18S) Idem.

(189) Diário de Lisboa, 20.X.65. A carta assinada pelos candidatos de Lisboa (Acácio Gouveia, Adão e Silva, A. Felix Castanheira, Salgado Zenha, Gustavo Soromenho, J. Catanho de Menezes, J. Medeiros Ferreira, J. Paradela de Oliveira, Mário Soares, Sottomayor Cardia, Nuno Rodrigues dos Santos e Raul Rego) representa também as posições dos candidatos do Porto, de Leiria e de Viseu. 
Governador Civil, condições de eligibilidade, desde que substituídos os dois candidatos declarados ineligíveis, persiste porém no seu propósito de ir às urnas. Nesse sentido, solicitam a 2 de Novembro ao Presidente da República adiamento das eleições por 30 dias. Só perante a recusa enveredarão também pela desistência, a 6 de Novembro, véspera das eleições.

A participação na campanha eleitoral não se limitou porém apenas às listas que cedo se pronunciam pelo abstencionismo. Monárquicos independentes e um grupo de católicos tomaram também posição perante o momento eleitoral.

Os primeiros através de um documento em que, contrários à abstenção, porque isso, «seria colaborar no amolecimento dos caracteres, iludir os governantes e minar toda a obra de Portugal», tornam público que «foram apenas circunstâncias do condicionalismo criado pelo actual regime que impossibilitaram a realização do intento» de se apresentarem novamente ao eleitorado em Lisboa. Abstencionistas involuntários, os monárquicos democráticos aproveitam o momento para denunciar a falta de informação ao povo português sobre os dados fundamentais para a equação e compreensão dos problemas que é chamado a enfrentah E enaltecem a dignidade do manifesto da Oposição Republicana, embora discordando de algumas das suas opiniốes, concordando por fim, com a atitude e as razões da desistência $\left({ }^{190}\right)$.

Também os católicos progressistas vieram novamente a público com um Manifesto apoiar o "significado moral e cívico» do Manifesto da Oposição e da exposição posterior ao Presidente da República. «Se há uma batalha de coragem neste país, a Oposição ganhou-a», já que «se ergueu na defesa de valores e direitos que, para um cristão são, ou devem ser, sagrados, valores e direitos que um poder que se reclama do catolicismo tem vindo sistematicamente a violar e a ofender», tais como o «direito à existência e a um nível de vida digno», o "direito à liberdade de manifestar e difundir as suas ideias», o «direito de possuir uma informação verdadeira dos acontecimentos públicos», o «direito de reunião e associação», o «direito de tomar parte activa na vida pública». Denunciam as perseguições da polícia política, o processo eleitoral «sem dignidade nem verdade, o baixo nível intelectual do país, a ausência de informação, o tratamento dado à juventude que luta pelos seus direitos, e a disparidade que neste como noutros pontos existe entre o pensamento da Igreja e a política do Governo». E a propósito do problema ultramarino mani-

(190) Diário de Lisboa, 4.XI.65. 


\section{António Sérgio}

festam simpatia pela "progressista realização do acesso à soberania dos povos» - na expressão de João XXIII-e defendem o «diálogo estabelecido na liberdade, na verdade, na justiça e no amor» $(1 \mathrm{M})$.

Nas duas eleições de 1961 e 1965, a Oposição optou pela abstenção, não deixando porém de aproveitar o período de campanha para intervir, não tanto «eleitoralmente» quanto politicamente, para denunciar a impossibilidade de eleições livres e criticar a política do Governo, sobretudo no domínio da política ultramarina, porventura o mais grave e o maior problema nacional da década.

Será preciso esperar pela queda de Salazar e sua substituição por Marcelo Caetano, e pela «liberalização» encetada em 1968, para que nova estratégia fosse adoptada e seguida.

\section{A primeira disputa nacional das eleições legislativas pela Oposição (1969)}

A entrada de Marcelo Caetano para a chefia do Governo, no Outono de 1968, e a liberalização do regime que então se iniciou, vão dar à oposição razões para repensar a sua actuação nas eleições de 1969. Disposta a tirar partido da abertura esboçada, a Oposição decide responder ao repto liberalizante do sucessor de Salazar. Em Dezembro de 1968, um sector dela - os socialistas democráticos liderados por Mário Soares, António Macedo, J. Magalhães Godinho, T. Carvalho dos Santos e Raul Rego - aprovam, num encontro nacional, um Manifesto à Nação (192).

«Para se estabelecer o diálogo político é fundamental haver liberdade de organização e actuação para as forças políticas que compõem o agregado nacional, acabando de uma vez com o monopólio do poder ao serviço de um partido único, e um mínimo de segurança para as pessoas, contra os arbítrios, por demais conhecidos, da polícia política e da censura». Nesse sentido, se exigia a promulgação de uma lei de imprensa, uma amnistia politica, a extinção das «medidas de segurança» e uma nova lei eleitoral (193).

Nos começos de 1969, é constituída em Lisboa, com vista a preparar o acto eleitoral, uma Comissão Promotora de Voto,

(1M) Felicidade Alves (ed.) ob. cit., pp. 175 e ss.

(192) A 16 de Dezembro de 1968 solicitaram em vão ao Presidente do Conselho a sua divulgacão.

(“3) J. Magalhães Godinho, «A fraca memória (?) de M. Caetano» ob. cit., e M. Soares, ob. cit., p. 236. 
integrada por nomes representativos dos mais variados sectores da Oposição de cuja constituição é dado conhecimento ao Presidente do Conselho de Ministros, a 20 de Janeiro de $69\left({ }^{194}\right)$.

Propunha-se essa Comissão Promotora de Voto «contribuir para a concretização das condições regulamentares e de consciência cívica conducentes à seriedade e autenticidade do próximo acto eleitoral».

Considerando que até aí «as autoridades procuraram e conseguiram tirar aos actos eleitorais qualquer significado de expressão da vontade da Nação», afirma como indispensável «a criação de um clima novo, que permita a intervenção de todas as tendências em competição sadia e ordeira», para o qual se propõe colaborar. Solicita assim ao Governo um novo recenseamento eleitoral, uma nova lei eleitoral que possibilite a fiscalização pré-eleitoral e eleitoral, a igualdade de tratamento aos contendores, a liberdade de organização e actuação das forças políticas, uma campanha de esclarecimento de opinião pública sobre as condições e exercício do direito de voto, e uma campanha junto das entidades responsáveis pelas operações eleitorais para respeitarem a autenticidade do voto $(195)$.

Numa segunda exposição ao Presidente do Conselho depois de uma referência ao desejo de ver alargada a capacidade eleitoral quer aos maiores de 18 anos, quer aos portugueses residentes no estrangeiro, que porém se não reivindica, pormenorizam-se apenas as reclamações mais urgentes e as correspondentes propostas de solução: que se restabeleça como condições de eligibilidade, o ter capacidade eleitoral, e não o estar recenseado já que o recenseamento é deficiente; que se suprima, como causa de ineligibilidade, «o professar ideais contrárias à existência de Portugal como Estado independente aos princípios fundamentais de ordem social estabelecida», por ser «uma cláusula que não é clara e expressamente definida, que fica dependente do critério de interpretação, e até do maior ou menor sectarismo político da autoridade que tem que aceitar ou recusar as candidaturas» (196); a admissão de «delegados eleitorais nas assembleias eleitorais» para fiscalização do acto eleitoral; a posse, por parte desses delegados, de cópias autênticas dos cadernos

(194) Qf $e_{e} i_{e} i c Q_{6 S} d_{e}$ Outubro de 1969, Lx., Europa-Amériea, e J. Magalhães Godinho «A fraca memória (?) de M. Caetano», cit. (195) As eleições de Outubro de 1969, Europa-Amériea, p. 45. $C^{96)}$ Idem, p. 49. 
eleitorais, para realização dessa fiscalização; a obrigatoriedade de passagem de certidões quer do número de votos obtidos por qualquer candidato, quer do acto de apuramento; obrigar a realização do apuramento no próprio dia da eleição; alteração do regime eleitoral no sentido de «eleição por lista em círculos distritais, ressalvados os casos das cidades de Lisboa e Porto, cujos concelhos instituiriam circulares próprias, passando os demais concelhos a formar círculos eleitorais distritais autónomos, mas com a obrigação de garantir à minoria um quarto do número de deputados, desde que essa minoria alcance, no acto de votação, pelo menos do quinto ao quarto dos votos contados no apuramento» (197); defesa do segredo do voto, com a impressão das listas em papel igual; integridade das urnas, com a inspecção prévia pelos delegados eleitorais e condições de vigilância; transferência da apresentação de reclamações e recursos aos tribunais administrativos, de nomeação governativa, para os tribunais da relação; a abolição da censura durante a campanha eleitoral, a liberdade de reunião e a igualdade de tratamento dos vários candidatos.

A 3 de Fevereiro, porém, o Governador Civil de Lisboa notificou a Comissão Promotora de Voto de que o Governo lhe recusara existência legal e proibira por conseguinte a sua actividade, alegando que ela pretende intervir em matéria que é da exclusiva competência das entidades públicas; que pretende fazer campanha antes das listas serem aceites e, como tal, restaurar os partidos políticos. Contra tal medida protesta a Comissão junto do Presidente do Conselho, esclarecendo que a sua intervenção é de índole diversa, não colide por isso com a do Governo, só na fase pré-eleitoral se pode fazer, e que está longe de se poder identificar com a actuação de um partido. Mais: insiste que o seu funcionamento não pode depender da autorização, como se de qualquer associação se tratasse, já que se trata de um «agrupamento sui generis, que nem cabe na esfera jurídica das associações» (198).

Esta proibição governativa não impede porém que a Oposição se prepare para as eleições. A 13 de Abril é promovido em Alcobaça um primeiro encontro nacional de elementos da oposição favoráveis à intervenção. Em Maio, organiza-se em Aveiro de 15 a 17, o II Congresso da Oposição Democrática que, embora não tenha abordado expressamente o problema da intervenção eleitoral, contribui para o reforço dos

(197) Idem, p. 51.

(1M) Idem. 
laços de unidade entre a Oposição. Várias Comissões Eleitorais Democráticas (CED) começam a ser constituídas pelo país com o intuito de preparar a participação da Oposição nas próximas eleições de Outubro.

Foi precisamente por iniciativa da CED de Leiria que a 15 de Julho de 1969 se reúnem em S. Pedro de Muel, delegados distritais de todas as demais comissões do País, à excepção da de Bragança, tendo sido aprovada nesse II Encontro Nacional da Oposição, além de uma Plataforma de Acção Comum (contendo alguns princípios e reivindicações essenciais a defender nos planos político, económico, cultural, sanitário, administrativo, ultramarino e internacional), uma orientação - a constituição de uma frente coesa da Oposição e a participação nacional, e até final, no próximo acto eleitoral - e algumas resoluções entre as quais a de «reclamar do Governo a cópia dos cadernos eleitorais, a garantia da físcalização do acto eleitoral, o acesso a todos os meios de informação, incluindo a RTP e a rádio, e a supressão da censura» (199).

A fim de dar execução ao que então é acordado, decide-se também a constituição, a nível distrital de "comissões partidárias» que deveriam integrar, em igual número, representantes dos vários sectores da Oposição, na disposição de concorrerem. Essa paridade é efectivamente conseguida na grande maioria dos distritos. Em Lisboa, Porto e Braga, porém, a unidade não é conseguida, e dois sectores da oposição- organizados em torno da CEUD e da CDE - surgem em finais de Julho a disputar as eleições. Rompera-se a coesão votada, mas cumpria-se a decisão de participar a nível nacional.

$\mathrm{Na}$ base desta cisão estavam processos de intervenção ou estratégias diferenciadas e inconciliáveis. Enquanto a CDE (em que se agrupavam católicos progressistas, democratas independentes e comunistas) preconizava uma metodologia basista, de fomento de participação alargada das bases, através da criação de Comissões de Freguesia e sócio-profissionais, que posteriormente elegeriam os seus representantes à Comissão Distrital, rejeitando por isso «a principiologia dos «acordos de cúpulas», do "equilíbrio entre as notabilidades» $\left(20^{\circ}\right)$, a CEUD (em que sobressaíam os socialistas democratas, liderados por Mário Soares, próximos da Internacional Socialista) insistia à partida na necessidade de obter, na direcção distrital, uma paridade de representação das correntes em

(109) Idem, p. 61.

(20) Idem, p. 67. 
jogo, recusando por isso a principiologia da CDE que considerava oportunista, e defendendo que «o critério dominante de estruturação do movimento de unidade democrático deve ser não o do purismo ideológico, mas o da eficácia, conjugado com a necessidade de proteger os quadros face à repressão» (201).

No fundo porém disputava-se a direcção do movimento de oposição ao regime. «Os socialistas — revelou-o Mário Soares numa das cartas de polémica com Armando Bacelar, publicadas em $A$ Vida Mundial (202) —não estão dispostos a deixarem-se comandar por um sector que se pretende hegemónico e que se serve de elementos que não declaram a sua filiação partidária, para obter maiorias fictícias e assim impor o seu predomínio»».

Por isso se goraram várias tentativas de reconciliação, quer nacionais, quer locais, em que avultaram as promovidas por uma Comissão de Apelo para a Unidade.

Embora dividida em três distritos, a Oposição Democrática apresenta-se eleitoralmente pela primeira vez na história do regime em quase todo o continente e Ilhas (à excepção de Portalegre, onde o processo de candidatura não pôde ser ultimado a tempo; de Bragança onde desistiu no decurso da campanha; de Angra do Heroísmo e da Horta). Em Moçambique foi rejeitada pelas autoridades administrativas uma lista da CED, liderada por Almeida Santos, com o fundamento em que os candidatos não fizeram prova de serem portugueses de origem e de residirem em Portugal há mais de cinco anos.

A 3 de Agosto, novo avanço organizativo se regista no III Encontro Nacional do Movimento Democrático Eleitoral, em Lisboa, com a decisão de se criar uma coordenadora, integrada por representantes de Lisboa (3), de Santarém (1), de Leiria (1), do Norte (5), do Centro (5), e do Sul (5) (203).

Além da Oposição Democrática, também os monárquicos dissidentes da Causa Monárquica se apresentam novamente às eleições pelo círculo de Lisboa, nas linhas de tomada de posição iniciadas em 1957, com a designação de Comissão Eleitoral Monárquica $\left({ }^{204}\right)$. Anunciada publicamente a

(TM) Idem, p. 75 .

C202) Vida Municipal 19/IV/69 p. VII.

í2) Cadernos Necessários, Porto, Aproveitamento, pp. 170-178.

(204) Da lista de candidatos faziam parte os nomes de Rolão Preto, Barrilaro Ruas, Luis Vaz de Sampayo, Fernando Honrado, Francisco Lopes Roseira, Joaquim Toscano de Sampaio, Luiza Manuel de Vilhena, Fernando Teixeira Viana, M. Magalhães e Silva, Fernando Sylvan, Fernando Costa Quintais e António Pardete da Fonseca. 
12 de Setembro, a Comissão Eleitoral Monárquica resultava da aliança da já conhecida Liga Popular Monárquica (205) com a recém formada Renovação Portuguesa (206). Reivindicando-se do «nacional-personalismo», a CEM assume como programa a «defesa intransigente da Pátria e a defesa não menos intransigente das liberdades humanas» $\left({ }^{207}\right)$, porque «a independência de Portugal passa pela liberdade dos Portugueses» $\left({ }^{208}\right)$. Do seu programa constava de facto, tanto a defesa e desenvolvimento do Ultramar como a restauração das liberdades, a modificação radical da estrutura económica (com a abolição do corporativismo), a agricultura, a habitação, a emigração, a previdência, o ensino, a política externa $\left({ }^{209}\right)$.

A Causa Monárquica, não deixou de vir a público desautorizar a CEM $\left({ }^{210}\right)$, reivindicando que só ela «legítima e hierarquicamente é responsável pela acção política monárquica», e que os demais «não têm o direito de falar, criando equívocos políticos»». Dias depois (211), recomendava a abstenção para, em declarações publicadas um mês depois $\left({ }^{212}\right)$, alterar essa oposição e recomendar «aos monárquicos que não só se abstenham de votar nas listas da Oposição, mas que votem naqueles cujos nomes dêm garantias inequívocas de defender a integridade territorial e moral da Nação e os princípios perenes da consciência nacional, podendo eliminar, com total independência e coerência, os nomes que não dêern essa garantia» $(213)$.

Ao lado das forças intervencionistas não faltava quem preconizasse a abstenção. A Acção Democrática Social, onde avultavam os nomes de Cunha Leal, Dias Amado, Acácio Gouveia, Nuno Rodrigues dos Santos, Sá Cardoso, Alberto Saave-

$\left(2^{\circ 5}\right) \wedge$ Liga Popular Monárquica publicou a 29 de Setembro um comunicado defendendo a participação eleitoral, mas no caso de «distritos em que não foi possível a apresentação de uma lista monárquica, optaremos - diziam - por uma abstenção total, mas activa, no campo eleitoral», "preferindo uma ausência digna a uma maligna representacão».

(206) Ċriada em Maio de 1969, para «influir decisivamente na construção de uma vida política progressiva», segundo o manifesto então publicado na Imprensa, os seus primeiros dirigentes foram designados num almoço então realizado no Ribatejo, a que presidiu Rolẫo Preto, 26 de Setembro de 1969, Cf. Vida Mundial, pp. X-XI.

(m) Dossier da CEM, Lisboa, 1973, p. 17.

(208) Idem, p. 18.

$\left.\mathrm{C}^{209}\right)$ As Eleições de Outubro de 69, p. 39 e ss.

(210) A 17.IX.69.

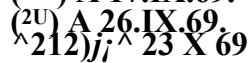

$\left.\mathrm{C}^{213}\right)$ As Eleições de Outubro de 69, pp. 138-139. 
dra, entre outros, alegando a inexistência de condições mínimas de participação, defendia, num documento tornado público a 12 de Março, e mais tarde confirmado por novo documento, a 2 de Outubro, que a Oposição não devia correr o risco de uma aventura eleitoral, já que «a participação da Oposição em actos eleitorais é uma forma de colaboração com a situação». Por isso, "como única forma de cumprir deveres cívicos» $\left({ }^{214}\right)$, era apontada a abstenção.

Idêntica posição era assumida por uma auto-proclamada Terceira Força, de credo republicano, que se definia «movimento nacional, popular e democraticista, nem liberal nem socialista, anti-corporativista e anti-monárquico» $\left({ }^{215}\right)$.

Também em Braga, surgiu uma lista de «nacionalistas independentes», como resultado da insatisfação local pela escolha de candidatos do distrito pela União Nacional, lista essa que viria porém a desistir por intervenção do próprio Presidente do Conselho.

O Governo, por seu turno, de acordo com as exigêncais formuladas pela União Nacional, de Melo e Castro, de igualdade eleitoral para todas as candidaturas, «não só no acesso aos cadernos eleitorais, como no controlo do próprio acto de eleição e nos meios necessários para preparação e apresentação dos elencos de candidatos» $(216)$, garante formalmente pela primeira vez o acesso aos cadernos eleitorais $\left({ }^{217}\right)$, autoriza a constituição de comissões eleitorais (com um mínimo de 50 eleitores) e a fiscalização do acto pelos representantes das candidaturas. Dizemos «formalmente» porque, na prática, a cópia dos cadernos continuou a ser dificultada para a Oposição enquanto a União Nacional dispunha gratuitamente de cópias integrais $(218)$.

Mas, apesar de se admitir, também pela primeira vez, um período pré-eleitoral, anterior ao período da campanha,

(214) Idem, p. 106.

(215) Idem, p. 114.

(216) Comunicação ao País do Ministro do Interior, Diário da

Manhã, 28.VI.69.

(217) Melo e Castro na Posse das Comissões Distritais da UN de Braga e Viana do Castelo, in Diário da Manhã, 30.VIII.69.

(218) Cf. Magalhães Godinho, «A fraca memória (?) de Marcelo Caetano» (4 artigos) in O Jornal de 11.VIII.80 a 29.VIII.80. O Governador Civil com efeito, facultaria a consulta dos cadernos que, tendo em conta o prazo da entrega das listas de candidatura, teriam que ser feitas em 20 dias, e apenas no Governo Civil, condições de tempo e de espaço manifestamente insuficientes para copiar integralmente listas de milhares de eleitores. No entanto, foi graças a essa possibilidade que Alçada Baptista conseguiu a preciosa classificação socio-profissional do eleitorado recenseado na cidade da Covilhã (cf. A. A. Baptista, Documentos Políticos, Lisboa, Morais, 70, p. 70-71). 
destinado a «facilitar a escolha dos candidatos e a elaboração dos respectivos processos de candidaturas», para cujo efeito se garante o «direito de reunião de eleitores» $(219)$, a liberdade eleitoral nomeadamente a liberdade de propaganda, continuou porém a ser fortemente condicionada: autorizam-se reuniões e sessões de propaganda, mas desde que não ultrapassem em duração a meia-noite e sejam participadas às autoridades com a antecedência mínima de 48 horas, podendo a elas assistir essas mesmas «autoridades administrativas e policiais que as deverão dissolver quando se verifique incitamento à subversão, desobediência, resistência, injúria à autoridade ou outra infracção grave à lei»; continuam proibidas reuniões ou manifestações de rua; persiste a censura prévia a todo o material de propaganda, devendo além disso todos os manifestos e documentos ter editor responsável; a afixação de cartazes é limitada a espaços a esse efeito destinados, e altifalantes apenas são consentidos em recintos fechados; é proibido o uso de edifícios públicos para campanha eleitoral, e os acessos aos meios de informação fica reduzido às empresas particulares de rádio $\left({ }^{2 \circ}\right)$. A paridade de condições de propaganda e de concurso entre forças da União Nacional e da Oposição continua assim a ser legal e administrativamente desrespeitada.

Também o regime eleitoral e de recenseamento permanecem basicamente inalteráveis, apesar de ter sido legalmente alargado o voto feminino. Mediante a Lei n. ${ }^{\circ} 2137$ de 26.XII.68 abolira-se efectivamente a discriminação entre homens e mulheres em matéria eleitoral. Mas, a pretexto de recusar «processos de formação acelerada de cidadãos eleitores» $\left({ }^{221}\right)$, o governo persistiu em manter as formas tradicionais de recenseamento que, como reconheceria o próprio Ministro do Interior, assentavam grandemente na inscrição oficiosa (que se reconhecia defeituosa) e só minoritariamente no livre requerimento individual. Dos 1.816.148 eleitores inscritos em 1969, por exemplo, só 27.998 o haviam sido por solicitação individual. Contentou-se o Governo em registar o aumento de nercentagem de eleitores, que atingiu efectivamente o melhor resultado de sempre: $19,9 \%$ de população total, mais $37,6 \%$ do que o recenseamento de 1965 .

A Oposicão reunida em Leiria no seu IV Encontro Nacional em 22 de Setembro, não deixou de analisar as altera-

(219) Nota do Ministro do Interior, in Diário da Manhã, 12.VIII.69.

(220) Cf. Diário da Manhã, 23.IX.69.

(221) Discurso do Ministro do Interior G. Rapazote, in Diário da

\section{Manhã, 28.VI.69.}


ções à Lei eleitoral de 10 de Setembro $(222)$, e de sobre elas formular um protesto por se terem «incluído ou integrado disposições que podem tirar a legitimidade ao acto eleitoral e impedir a livre expressão da opinião popular», como a possibilidade de os governadores civis recusarem candidaturas, e por não estarem ainda com eles «preenchidos os requisitos necessários para que o acto eleitoral se revista de condições susceptíveis de assegurar a sua integral autenticidade e a indispensável igualdade de exercício dos direitos eleitorais entre as listas concorrentes»». A Oposição exige, por isso, o pleno e livre funcionamento das Comissões Eleitorais, o fornecimento oficioso de uma cópia autêntica do recenseamento do círculo ao mandatário de cada lista, o aumento de delegados de fiscalização, o fornecimento gratuito de todas as listas pela Imprensa Nacional, a igualdade de tratamento e acesso à TV-rádio, e a abolição da censura ( ${ }^{223}$ ).

Além disso, essas mesmas alterações à legislação eleitoral seriam mais detalhadamente criticadas por expoentes juristas da oposição que as consideraram insuficientes (Acácio Gouveia e J. Magalhães Godinho) (224), aconselhando por isso a própria oposição à desistência, bem como ainda pela CEUD de Lisboa $(225)$.

Perante a resposta dada pela Presidência do Conselho ao protesto de Leiria, novo documento é elaborado no V Encontro Nacional da Oposição Democrática em Coimbra, a 13 de Outubro, em que são apresentadas novas queixas a M. Caetano contra as «arbitrariedades do Poder», «contra a ilegítima intromissão do governo na campanha eleitoral, contra a utilização da EN e da RTP para propaganda da União Nacional; contra a actuação da censura, contra a arbitrária actuação dos Governadores Civis, contra a intimidação de que têm sido alvo os candidatos, as comissões eleitorais e os eleitores». E como «atitude comum futura» decide a Oposição «não se submeter a qualquer pretenção ilegal das autoridades administrativas», «não aceitar submeter a qualquer visto ou censura prévia os documentos directamente emitidos pelos candidatos», e «não

(222> As alterações consistiam basicamente na alteração de 20 para 50 do número de proponentes de candidaturas; no restabelecimento de delegados eleitorais para as assembleias e seç̧ões de voto; no reconhecimento transitório de comissões eleitorais ;e no pagamento pelo Estado do custo das listas que obtenham $20 \%$ dos votos.

(223) Vida Mundial 26.IX.69, III e IV; e As Eleiçốes de Outubro de 69, p. 92 e ss.

(224) Vida Mundial, 19.IX.69, pp. XIV e XV.

i225) As Eleições de Outubro de 69, p. 98. 
aceitar como legítimas interpretações manifestamente erróneas da lei, nomeadamente no que respeita às questões do visto prévio e da fiscalização do acto eleitoral» $(226)$.

Efectivamente, a Oposição ia dando conta através de sucessivos comunicados das múltiplas dificuldades encontradas na realização da sua propaganda eleitoral: apreensão de material pelas forças policiais, proibições de conferências de imprensa e de sessões, etc. $\left({ }^{227}\right)$. Alguns candidatos a deputados viram os seus nomes rejeitados pelos Governadores Civis, quer porque acusados de professarem ideias contrárias à ordem estabelecida, (Humberto Soeiro em Braga; Alberto Bernardo da Costa em Leiria; Blasco H. Fernandes em Santarém; e Firmino Martins da CDE em Lisboa), quer por se alegar não terem residido no país nos últimos 5 anos (Victor de Sá em Braga).

Apesar de tudo, a Oposição desenvolveu uma importante campanha eleitoral que, embora não decorrendo sob o signo da unidade, se moveu em torno de objectivos políticos comuns, tais como a democratização, o desenvolvimento e a solução do problema ultramarino.

Entre as medidas mais preconizadas para a democratização da vida política, figuram entre os vários Comunicados das Comissões Eleitorais, a restauração das liberdades fundamentais, a extinção e a supressão dos aparelhos repressivos do sistema (PIDE, Censura, Tribunais Plenários, medidas de segurança), a libertação dos presos políticos e a reintegração dos afastados por razões políticas; a restauração da separação dos poderes com a independência do poder judicial; o restabelecimento do sufrágio directo na eleição do Presidente da República e do presidencialismo unicéfalo; a legalização dos partidos políticos, a promulgação de uma nova lei eleitoral e a realização de novo recenseamento eleitoral; uma nova lei de imprensa; a abolição do corporativismo e a liberdade sindical; a descentralização administrativa, a electividade dos municípios e a regionalização.

A denúncia do subdesenvolvimento e dos seus sintomas económicos, sociais e culturais é acompanhada também de uma série de propósitos desenvolvimentistas: suster o fluxo emigratório e promover o regresso dos emigrantes com o desenvolvimento da indústria e a modernização da agricultura; combater o latifúndio e o capital monopolista, mediante a realização de uma reforma agrária e a nacionalização de bancos

(226) Idem, p. 78.

(227) Vida Mundial, 17.X.69, p. 43. 
emissores e de empresas que dependam da segurança e economia nacionais; democratizar e desenvolver o ensino e a cultura; garantir a liberdade religiosa; melhorar as comunicações; enfrentar o problema da habitação; reestruturar os serviços de assistência médica e de previdência social; promover socialmente a mulher; aumentar o nível de vida; planificar o turismo de massas; incrementar o desporto; traçar uma política de juventude. E a este nível que surgem, pela primeira vez, nítidos conteúdos socializantes nas propostas políticas da Oposição, nomeadamente, as nacionalizações e o controlo operário.

Mas o principal problema político da campanha, foi a questão ultramarina, sobre o qual a oposição assumiu variadas posições, desde o preconizar uma simples advertência para o perigo da situaçã̃o (Aveiro) passando pela defesa de um amplo debate nacional sobre a questão (Braga, Évora), até preconizar a autodeterminação, enquanto ligada à libertação dos portugueses (C. Branco), ou a autodeterminação como direito, cujo reconhecimento seria a base de uma solução política negociada para conduzir à paz e ao fim da guerra (Lisboa, CDE e CEUD) (228).

A mobilização política conseguida pela Oposição com a campanha eleitoral foi sem dúvida superior aos resultados por ela obtidos que, apesar de tudo: obrigaram a União Nacional, a uma das mais baixas percentagens de votos da sua história: $54,7 \%$.

Além disso, a denúncia internacional por parte da oposição das limitações da sua actuação, de que a expulsão da delegação da Internacional Socialista, que viera para observar as eleições $\left({ }^{229}\right)$, foi eloquente testemunho, serviu para reduzir o efeito de legitimação externa do regime, que se procurava com a eleição.

\section{A participação bloqueada: a última abstenção (1973)}

A participação da Oposição nas eleições de 1969 fizera-se em plena liberalização marcelista. A partir de 1971, porém, desfaziam-se as ilusões de abertura perdendo-se as duas grandes oportunidades de mudança gradual do regime: a revisão da Constituição em 1971 e a eleição presidencial em 1972.

(228) As Eleições de Outubro de 69.

(229) Uma delegação da Internacional Socialista chegou a Lisboa a 20.X.69 para observar as eleições. Foi expulsa a 21. Cf. As eleições de Outubro de 69 .... 
Quando em 1973, têm lugar de novo eleições para a Assembleia Nacional, a situação política no país era outra, e a Oposição tinha já perdido as veleidades de uma disputa leal das umas com o Governo, que se atrevera a manter quatro anos antes.

Com efeito, a situação política endurecera. Os apoios internos e externos do governo diminuiram e, em contrapartida, recrudescia a repressão. Radicalizara-se por isso a acção da oposição. Nas frentes de guerra, os movimentos de libertação conseguiram progressivamente maior solidariedade e audiência internacional, fazendo-se aceitar como observadores na Comissão de Descolonização da ONU e nos organismos internacionais $\left({ }^{230}\right)$. Dessa maneira acentuava-se o isolamento diplomático do governo marcelista, apesar das tentativas de estreitamento de relações com os governos de Londres, Paris, Washington, Madrid e Pretória.

Internamente, radicalizava-se e ampliava-se a luta da oposição com o aparecimento de novas frentes. A luta armada, com ataques pontuais a alvos militares, desenvolvia-se por parte de algumas organizações revolucionárias. As movimentações estudantis de protesto contra a guerra e repressão atingiam níveis e dimensões inusitadas. Sectores católicos desencadeavam no Continente e em Moçambique com grande impacto interno e internacional protestos abertos contra a política de guerra e contra os massacres recentemente divulgados, perpetrados nos cenários de guerra.

Os apoios a Marcelo Caetano diminuiam também pela direita, onde os sectores mais conservadores se movimentavam contra as ambiguidades da política ultramarina do seu governo, com particular eco entre militares e antigos combatentes $\left({ }^{2 \mathrm{~S}}\right)$.

Em face desta situação a Oposição Democrática dispunha-se a entrar na Campanha eleitoral ciente dos limites de actuação, mas disposta a explorar as possibilidades de aproveitamento da margem de liberdade concedida.

$03 .^{\circ}$ Congresso da Oposição Democrática, realizado em Aveiro de 4 a 8 de Abril de 1973, votara por isso entre as suas conclusões, o aproveitamento político das eleições de

(230) A independência da Guiné, proclamada pelo PAIGC nas matas de Medina do Boé, nos finais de Setembro de 1973, será inscrita na agenda da Assembleia Geral da ONU, pouco depois, que aprovaria o pedido de retirada das tropas portugueses daquele território em Novembro de 1973.

(231) O Congresso dos Antigos Combatentes do Ultramar teve lugar no Porto em começos de Junho de 1973. 
Outubro: «As próximas eleições para deputados abrem largas perspectivas ao Movimento Democrático. Devem ser encaradas como um período excepcional para a abertura do Movimento a todas as camadas populares. Esse período, o ano eleitoral no seu todo, oferece condições favoráveis, para um aproveitamento organizativo. Deve-se, pois, participar nelas, aproveitando as mínimas garantias de actuação política para desenvolver uma larga batalha de massas pelos objectivos democráticos fundamentais. Sem quaisquer ilusões (ou erros) eleitoralistas que condicionam ou desviem o Movimento, deve este procurar organizar-se visando a sua continuação para além das «eleições» encaradas e apenas como um momento alto da sua acção pela Democracia». E acrescentava-se: «Um aproveitamento correcto das eleições por parte da Oposição Democrática não dá ao regime qualquer legitimidade, antes pelo contrário, obriga-o a desmascarar-se; logo, é politicamente importante» $\left({ }^{232}\right)$.

Esta linha era compartilhada por três sectores que compunham o Movimento Democrático Português: os socialistas do recém-criado Partido Socialista, liderado por Mário Soares, oriundos da extinta CEUD de 1969; os comunistas do PCP e seus mais próximos colaboradores que, nas eleições anteriores, haviam evidenciado quatro anos antes e eram agora identificados como «esquerda CDE».

No entanto, surgiram divergências quanto à perspectivação do. aproveitamento político das eleições. Enquanto os socialistas do PS e comunistas do PC insistiam numa perspectiva frentista de ampla unidade democrática, a «esquerda CDE», que pressionava no sentido da adopção de uma «política de classe» e da inclusão de objectivos de luta mais avançados, expressamente anti-capitalistas, abandonou o MDP na cisão de 8 de Julho de 1973.

É a luz destas directrizes dominantes que no Encontro Nacional do Movimento Democrático Português, em que se fizeram representar as Comissões Democráticas Eleitorais de Beja, Braga, Coimbra, Evora, Faro, Leiria, Lisboa, Porto, Setúbal e Vila Real, se analisam as possibilidades de participação no acto eleitoral. Enquanto algumas comissões optam expressamente pela abstenção, alegando a inexistência de con-

(232) $3 .^{\circ}$ Congresso da Oposição Democrática. Aveiro, a 4 e 8 de Abril de 1973. Conclusões, Lisboa, Seara Nova, p. 147. 
dições mínimas de liberdade de participação eleitoral - como foi o caso de Braga e da Guarda - embora sem abandonar o trabalho político durante a campanha - outras enveredaram pela participação. Surgem assim, listas de candidatos em Aveiro, Castelo Branco, Coimbra, Évora, Leiria, Lisboa, Porto, Santarém, Setúbal e Ponta Delgada, vindo porém esta última lista a ser recusada, por alegada deficiente instrução do processo de candidatura. Geograficamente, a abstenção situa-se assim mais no Norte (Minho e Trás os-Montes), no sul (Beja e Faro) e em três distritos do interior (Guarda, Viseu e Portalegre), e nas Ilhas, enquanto a participação na campanha se situa de preferência no Centro e no litoral, nos grandes centros urbanos e mais industrializados. Apesar da desigualdade de atitudes, as Comissões Democráticas continuaram a reunir-se a nível nacional-como aconteceu a 30 de Setembro na Marinha Grande - aceitando coordenar as respectivas actividades.

Tentaram igualmente os monárquicos independentes reeditar a participação de 1969, mas o encontro da Convergência Monárquica, onde avultava agora a figura de Gonçalo Ribeiro Teles, viu-se proibido pelo Governador Civil de Lisboa, que invocou a necessidade de uma autorização da Causa Monárquica nunca antes reivindicada. Decidiram assim os monárquicos independentes criar Comissões Eleitorais Monárquicas de Intervenção Popular para, através delas, "participar na Campanha, sem ir às urnas», a fim de discutir os problemas fundamentais do panorama político português $\left({ }^{233}\right)$.

Também os Liberais, decepcionados com o fracasso da abertura marcelista, reunidos num encontro em Lisboa, em Julho de 1973, analisaram as possibilidades de intervenção sem contudo decidirem pela participação.

O Governo, conhecedor da disposição da Oposição de encarar «instrumentalmente» as eleições, decidiu contrariá-la, aplicando sanções aos candidatos ou membros das Comissões Eleitorais que convidem à abstenção (234), nomeadamente a privação de direitos políticos por 5 anos (e portanto, de emprego, para os funcionários públicos) a quem retirasse a candidatura já apresentada. E dá publicamente instruções aos Governadores civis para que se não consinta «qualquer tentativa para converter em agitação pré-revolucionária a campanha eleitoral» $\left({ }^{235}\right)$.

(") Vida Mundial, 7.IX.73.

(S4) Época, 11.IX.73.

(236) Epoca, 29.IX.73. 
Nesse sentido são reeditadas as prescrições limitativas de liberdade de propaganda já praticadas em 1969: legalização das Comissões Eleitorais, condicionamento legal das reuniões e sessões de propaganda, proibição de reuniões e manifestações de rua, assinatura de manifestos e documentos para circulação, limitação à afixação' de cartazes, censura política a todo o material de propaganda, proibição de altifalantes fora de recintos fechados, de utilização de edifícios públicos e da RTP e EN (23e).

A limitação da liberdade de actuação da Oposição, mais do que por disposições legais, seria porém levada a cabo por disposições administrativas, com pretextos legais, tais como: substituição de um candidato em Setúbal, considerado ineligível por suspensão de direitos políticos; prisão de militantes quando distribuíam propaganda; restrição do uso da palavra nas sessões de propaganda aos candidatos, e exigência de sujeição à censura dos textos dos discursos; arranque de cartazes da Oposição pela polícia; busca policial a residências particulares de oposicionistas; intimidações sobre colectividades para não cedência de salas para comícios; invasão de sedes pela polícia, e intervenção em reuniões de trabalho nas sedes da oposição; proibição, interrupção e encerramento de sessões de propaganda pelos representantes das autoridades; encerramento de sedes; proibição de conferências de imprensa; identificação policial de participantes em reuniões da Oposição; espancamento policial de manifestantes de rua; ameaças de extinção das Comissões Eleitorais; aplicação de multas a oposicionistas; interrupção de reuniões particulares em casas de oposicionistas, etc. $\left({ }^{237}\right)$.

Apesar de tudo, as Comissões Democráticas Eleitorais persistiram no aproveitamento possível da campanha para fazer a denúncia das limitações do próprio processo eleitoral, e ultrapassá-las até, vindo apenas a desistir da ida às urnas na antevéspera do acto eleitoral.

(2!6) Idem.

(w) Todas estas medidas repressivas e limitativas estão amplamente descritas e referidas em J. Soares Martins (ed.) Outubro: Eleições em Portugal, Vila Nova de Gaia, 1973. 


\section{Conclusão}

Como acabamos de ver, a oposição variou ao longo do regime. Variou em primeiro lugar na sua composição e unidade interna e, consoante ela, nos seus objectives e estratégias de actuação.

Mais do que de «oposição» deve falar-se de «oposições», de uma oposição com várias componentes, algumas das quais perfeitamente identificáveis política e ideologicamente, outras porém mais híbridas. Assim, ao lado de uma oposição comunista, talvez o sector mais facilmente identificável, do ponto de vista ideológico e organizativo, cuja actividade se desenvolveu mais ininterruptamente, apesar de flutuações de identidade, são detectáveis uma linha liberal-republicana, uma linha socialista-democrática, uma linha popular-monárquica e uma linha católico-democrática. As fronteiras entre estes sectores não são de todo rígidas ou estanques, nem a homogeneidade interna é neles completa. Cremos porém que com esta designação e divisão se detectam os elementos mais distintivos e caracterizantes dos vários grupos e linhas que se entrecruzaran! no seio da oposição eleitoral ao salazarismo.

Entre os liberais-republicanos incluímos os defensores da mudança de regime político, num regime republicano, democrático e parlamentar, aceitando para tanto a rectificação reformista do quadro constitucional, e preconizando simultaneamente a liberalização do regime económico, mediante a eliminação dos freios do sistema corporativo. São integráveis neste sector os republicanos do velho Partido Republicano Português, que estiveram no MUD, na candidatura de Norton de Matos e, embora não tão incondicionalmente, na de Quintão Meireles; que nas eleições de 1953 e 1957 mantiveram uma posição abstencionista de recusa «cívica» em pactuar com o sistema; que apoiaram Humberto Delgado em 1958 e apareceram ainda a subscrever o Programa para a Democratização da República em 1961, mas que, com o deflagrar das guerras de África tendem a desaparecer do quadro da oposição activa. E ao lado destes republicanos, são também integráveis neste sector os liberais que não aceitaram a colaboração que o regime lhes ofereceu, e o atravessaram numa posição de permanente crítica. Estão neste caso os homens da União Liberal Republicana, que se mantiveram fiéis a Cunha Leal, que o acompanharam na sua candidatura de 1949 e nas demais intervençôes públicas, que apoiaram Quintão Meireles em 1951, estiveram com o Directorio Democrático Social na intervenção de 1953 e na abstenção de 1957, apoiaram Humberto Delgado em 1958 e vão eclipsar-se na década de 60, para 
se manifestarem cívicamente em 1969 como Acção Democrático-Social e como Terceira Força, pugnando a abstenção como forma mais coerente de actuacão. Este liberalismo é de matriz distinta da da conhecida «ala liberal» da Assembleia Nacional a partir da legislatura iniciada em 1969.

O sector socialista-democrático é, porventura, o mais heterogéneo internamente. Agrupa todos os que preconizam a mudança de sistema político e de sistema económico numa perspectiva reformista e de conteúdos sociais avançados, mas defendendo a democratização da República e a liberdade económica. Estão neste caso os homens da primeira geração da Seara Nova, os velhos membros do Partido Socialista da última liderança de Ramada Curto, os sectores mais democráticos e socialistas da Aliança Republicana Socialista de 1931, os socialistas da nova União Socialista do pós-guerra, socialistas independentes de esquerda da renovação da Seara Nova nos finais da década de 50, homens da Acção Socialista Portuguesa dos anos 60' que formarão a CEUD em 1969 e, mais tarde, fundarão em 1973 o Partido Socialista de Mário Soares, e ainda alguns sectores de esquerda socialista da CDE de 1969, que se radicalizarão nos anos finais do regime. Constituem juntamente com os comunistas, e em rivalidade com eles, o sector mais importante da oposição eleitoral ao regime. Estiveram unidos no MUD e com Norton de Matos, mas na década de 50, a guerra fria e a "questão comunista» dividi-los-iam, aproximando-se uns do sector liberal-republicano, e com eles integrando o Directorio Democrático Social, preferindo outros mais de esquerda a colaboração com os comunistas no Movimento Nacional Democrático. A campanha de Humberto Delgado voltará a reuni-los, conferindo-lhes a liderança da oposição eleitoral. Na década de 60, com o Programa para a Democratização da República, pertence-lhes também de novo boa parte da iniciativa política das acções legais da oposição. Em 1969, estiveram de novo repartidos pela CEUD e pela CDE de Lisboa, Porto e Braga, vindo porém a aceitar a unidade de acção com os comunistas no Movimento Democrático Português em 1973.

O sector popular-monárquico agrupa, por seu lado, a globalidade dos monárquicos que, à margem da Causa Monárquica, fizeram oposição ao regime, desde os antigos integralistas defensores das liberdades institucionais e do sindicalismo social, que aceitaram apoiar individualmente os grandes movimentos unitários de oposição ao regime, desde o MUD até às candidaturas de Norton de Matos, Quintão Meireles e Humberto Delgado, ou concorreram mesmo organizadamente nas eleições de 1949 (Pequito Rebelo, no Alto Alen- 
tejo), até aos monárquicos que, a partir dos finais da década de 50, cindindo com a Causa Monárquica, decidiram aparecer e intervir organizadamente nas várias eleições de 1957, de 1961, de 1969 e de 1973. Visando todos eles a restauração e defesa do regime monárquico, aproximaram-se porém da restante oposição republicana pela defesa da restauração das liberdades política, cultural e económica.

Por último, o sector católiçoformado por todos os que, reclamando-se publicamente ou sendo publicamente identificados como militantes católicos (clérigos ou leigos), defendiam a democratização política e económica. Estão neste grupo, os poucos subscritores das reivindicações do MUD em 1945 (com destaque para o P. Alves Correia e para o ceadecista Francisco Veloso), os católicos sociais que na década de 50 vão formulando crescentemente críticas ao corporativismo, e os católicos progressistas que, sobretudo na década de 60 , multiplicam tomadas de posição de denúncia crítica da instrumentalização política do catolicismo pelo regime e da violação dos direitos humanos, na esteira das encíclicas sociais papais e dos documentos conciliares dessa década. Nunca organizados como tais, tiveram participações individuais de relevo nas lutas eleitorais a partir de 1957 (com a apresentação sobretudo das candidaturas de Alçada Baptista e Lino Neto), destacando-se além disso documentos colectivos nalgumas das eleições da década de 60. Inicialmente mais democrata-cristãos, acabariam porém por prevalecer neste sector, nos finais do regime, as perspectivas socialistas.

Consoante variaram os momentos de unidade e de divisão no interior da oposição eleitoral, assim variaram também as suas estratégias de actuação.

A primeira estratégia adoptada pela oposição, nos seus grandes momentos unitários da campanha do MỦ, em 1945, e da campanha presidencial de Norton de Matos, em 1949, foi uma estratégia de intervencionismo condicionado, convertida em abstencionismo à boca das urnas. A oposição, chamada a participar eleitoralmente estabelece unitariamente condições à partida para uma participação integral, aproveitando o período de campanha para denunciar o regime, exigir o seu derrube e a sua substituição por uma nova constitucionalidade. Não sendo aceites as condições postas, ou exigiam a democraticidade da concorrência eleitoral, a oposição desiste à boca das urnas, colhendo porém dividendos organizativos e políticos da contestação desenvolvida.

$\mathrm{Na}$ década de 50 (mais concretamente entre as eleições para a Assembleia Nacional de 1949 e 1957) assiste-se à divisão da oposição e ao aparecimento de estratégias contrapo s- 
tas. A assinatura pelo governo do Tratado do Atlântico Norte, em Abril de 1949, e o desencadear internacional e interno da guerra fria, cavaram divisões na oposição: de um lado, os democratas atlantistas que, defendendo o alinhamento político de Portugal com os países da NATO, procuravam forçar Salazar à democratizaçẫo do regime; do outro lado, os anti-atlantistas, para quem a assinatura do Tratado de Washington reforçaria e consolidaria interna e externamente o regime.

Enquanto os primeiros - reunidos sobretudo à volta do Directorio Democrático-Social - inflectem de rumo, e adoptant uma estratégia reformista do regime, acatando o seu quadro constitucional, chegando por isso a aceitar ir às umas nas legislativas de 1949 e 1953, os segundos - reunidos no Movimento Nacional Democrático - persistem na estratégia de derrube do regime com rotura constitucional, enjeitando por isso qualquer disputa das urnas e limitando-se ao aproveitamento da tolerância, concedida nas campanhas eleitorais. As candidaturas presidenciais de Quintão Meireles e Rui Luís Gomes, em 1951, incarnam precisamente esta dualidade de estratégias.

Nas eleições legislativas de 1957, no entanto, invertem-se tácticamente posições nas estratégias da oposição dividida. Os intervencionistas reformistas aparecem a defender a abstenção, alegando inexistência de condições de participação digna, enquanto nos sectores identificados com o MUD nos princípios da década, surge um novo intervencionismo táctico, mais disposto a disputar ao governo, frontalmente, o direito de existir como oposição, do que a aceitar as regras da concorrência proposta.

É assim que nas eleições presidenciais de 1958 essas duas estratégias, com as evoluções tácticas conhecidas ao longo da década, se traduzem na apresentação das candidaturas de Humberto Delgado e Arlindo Vicente, respectivamente. A dinâmica desencadeada pela primeira, forçará a segunda à desistência, acordada no conhecido Pacto de Cacilhas de finais de Maio de 1958. A oposição acaba por se unir momentaneamente em tomo da candidatura de $\mathrm{H}$. Delgado, que se propunha a demissão de Salazar dentro do quadro constitucional do regime. Saldava-se dessa forma o compromisso das duas estratégias até aí vigentes, associando-se o «intervencionismo até ao fim» da oposição partidária da rotura com a «aceitação táctica dos limites constitucionais» dos reformistas do regime.

O ludíbrio que vitimou essa estratégia unitária de compromisso determinaria, ao longo da década de 60, a adopção generalizada de uma atitude de abstencionismo denunciador 
por parte das oposições que, quer em 1961 quer em 1965, desistiriam alegando inexistência de condições de concorrência.

Só em 1969, após a abertura liberalizante do marcelismo, se vai assistir à reformulação da estratégia da oposição que, pela primeira vez, em eleições para a Assembleia Nacional, decide concorrer até ao fim, ao nível de quase todos os círculos eleitorais, e com várias listas: CDE, CEUD, CDM. Mais do que a reforma ou o derrube imediato do regime, ou a aceitação ou rejeição do seu quadro constitucional, é uma estratégia intervencionista virada para a instalação efectiva de um pluralismo político, visando contrariar o monismo não só da representação da Assembleia Nacional mas também do próprio regime político.

O fracasso dessa experiência, o bloqueamento da liberalização a partir da revisão constitucional de 1971 e consumado com a eleição presidencial de 1972, farão com que, nas últimas eleições do regime, em 1973, a oposição, apesar de unida, opte de novo pelo abstencionismo à boca das urnas, depois de explorar a campanha para denúncia da ausência de condições concorrenciais.

A crescente participação da oposição nos processos eleitorais do regime, com a crescente apresentação de listas distritais (2 em 1949, 3 em 1953, 4 em 1957, 10 em 1961, 5 em 1965, 22 em 1969, e 10 em 1973), não só não legitimou o sistema eleitoral e representativo mas antes atenuou o carácter plebiscitário e monístico de um e de outro.

Por outro lado, com o convite às oposições para participarem nas eleições, o regime pretendeu dividi-las, para marginalizar e reprimir as oposições comunista e socialista, e cooptar a oposição liberal e republicana. Essa estratégia govemativa, se não resultou nunca, no sentido de que nunca as oposições aceitaram o regime e a colaboração sequer pontual com ele, conseguiu pelo menos minar e dificultar a unidade interna das oposições. As dificuldades postas à sua expressão e organização permanente no campo legal levaram logicamente ao reforço das suas expressões e organizações ilegais e clandestinas, terreno que favorecia a hegemonia, só episodicamente contrariada ou discutida, das forças partidárias da rotura constitucional e das estratégias de aproveitamento meramente instrumental das eleições. 